\title{
- DisclaAmEn
}

This bock was prepared as an account of work soonsored by en moency of the United States Government.

warranty, express or imolied, of nor any agency thereot, nor any of thair employees, makes any

completeness, or usefulness of any information, soparatus product, of pror the scauracy.

represents that its use would not infringe privately owmed rights Reference herein to any

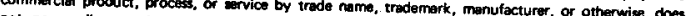

not necesserily constitute or imply its endorsement, recornmendation, of fevoring by the United

Shew Government or any agency thereot. in

necessarily state of reflict those of the United States Governntrent or any agency thereof.

\section{Washington: A Guide to Geothermal Energy Development}

Prepared for

\section{U.S. Department of Energy (USDOE) \\ Region X Office \\ Seattle, Washington}

Contract No. EY-77-C-06-1066

by

R. Gordon Bloomquist

Neil Basescu

Charles Higbee

Debra Justus

Stewart Simpson

Geo-Heat Utilization Center

June, 1980 


\section{DISCLAIMER}

This report was prepared as an account of work sponsored by an agency of the United States Government. Neither the United States Government nor any agency Thereof, nor any of their employees, makes any warranty, express or implied, or assumes any legal liability or responsibility for the accuracy, completeness, or usefulness of any information, apparatus, product, or process disclosed, or represents that its use would not infringe privately owned rights. Reference herein to any specific commercial product, process, or service by trade name, trademark, manufacturer, or otherwise does not necessarily constitute or imply its endorsement, recommendation, or favoring by the United States Government or any agency thereof. The views and opinions of authors expressed herein do not necessarily state or reflect those of the United States Government or any agency thereof. 


\section{DISCLAIMER}

Portions of this document may be illegible in electronic image products. Images are produced from the best available original document. 



\section{ACKNOWLEDGEMENTS}

This guide to geothermal energy development reflects the work of many individuals and groups and could not have been completed without their full cooperation and support.

The authors would like to express their appreciation and give special recognition to Dave Anderson and John Lund for allowing the authors free use of the materials developed for the Geothermal Resources Council publication "Direct Utilization of Geothermal Energy - A Technical Handbook."

Special appreciation is expressed to Eric Schuster and Mike Korosec for technical review of the Exploration chapter and the Glossary, Roald Bendixen for review of the Legal and Institutional chapter, and to Colleen Fry for editing the many drafts of the entire report.

Our special thanks to Gibb Johnson and Ramesh Venkajakrishnan of the University of Idaho Cartographics Department for the excellent diagrams and artist's sketches found throughout the report and including the front cover.

To June Hecht, without whose dedication to the preparation of the manuscript we would never have completed this report on time, our special appreciation. 

METRIC/ENGLISH CONVERSIONS

$$
\begin{aligned}
1 \mathrm{~m}^{3} & =35.3 \mathrm{ft}^{3}=264 \mathrm{gals} \\
1 \text { meter } & =3.281 \mathrm{ft} \\
1 \text { kilogram } & =2.2 \mathrm{bb} \\
1 \text { liter } & =0.264 \mathrm{gal}=0.0353 \mathrm{ft}^{3} \\
1 \text { liter } / \mathrm{sec}=.001 \mathrm{~m}^{3} / \mathrm{sec} & =15.8 \mathrm{gpm} \\
1 \text { joule } & =0.000948 \mathrm{Btu} \\
1 \mathrm{O} C & =(0 \mathrm{~F}-320) \times 5 / 9 \\
1 \mathrm{~m}^{2} & =10.76 \mathrm{ft}^{2}
\end{aligned}
$$

\begin{tabular}{|c|c|c|c|c|c|}
\hline $\begin{array}{c}\text { British Thermal } \\
\text { Units } \\
\text { (Btu) }\end{array}$ & $\begin{array}{l}\text { Cubic Feet } \\
\text { Natural Gas } \\
\text { (CF) }\end{array}$ & $\begin{array}{l}\text { Ki lowatt Hours } \\
\text { Electricity } \\
\text { (kwh) }\end{array}$ & $\begin{array}{c}\text { Barrels of } 0 i 1 \\
\text { (bbi) }\end{array}$ & $\begin{array}{l}\text { Short Tons } \\
\text { Bituminous coal } \\
\text { (T) }\end{array}$ & $\begin{array}{c}\text { Tons of } \\
\text { Refrigeration* }\end{array}$ \\
\hline $\begin{array}{c}1 \\
1000 \\
3413 \\
1 \text { Million } \\
3.41 \text { Million } \\
5.6 \text { Million } \\
25 \text { Million } \\
1 \text { Quadrillion } \\
\text { (Quad) (Q) }\end{array}$ & $\begin{array}{c}0.001 \\
1 \\
3.41 \\
1000 \text { (1 MCF) } \\
3413 \\
5600 \\
25,000 \\
1 \text { Trillion } \\
\text { (1 TCF) }\end{array}$ & $\begin{array}{c}0.000293 \\
0.293 \\
1 \\
293 \\
1000(1 \mathrm{MWh}) \\
1640 \\
7325 \\
293 \text { Billion }\end{array}$ & $\begin{array}{c}0.00018 \\
0.00061 \\
0.18 \\
0.61 \\
1 \\
4.46 \\
180 \text { Million }\end{array}$ & $\begin{array}{c}--- \\
0.0004 \\
0.00014 \\
0.04 \\
0.14 \\
0.22 \\
1 \\
40 \text { Million }\end{array}$ & $\begin{array}{c}--- \\
.0833 \\
.284 \\
83.3 \\
284 \\
466 \\
2083 \\
83.3 \text { Billion }\end{array}$ \\
\hline
\end{tabular}

NOMINAL FUEL HEATING VALUES

1 cubic foot natural gas $=1000 \mathrm{Btu}$

1 pound bituminous coal $=12,500 \mathrm{Btu}$

1 gal \#2 fuel oil $=1.42 \times 10^{5} \mathrm{Btu}$

1 Therm $=10^{5} \mathrm{Btu}$

1 barrel crude oil $=5.6$ million Btu

ENERGY UNIT CONVERSION CHART (100\% Efficiency)

*Defined as the heat of fusion of one ton of water, equal to 288,000 Btus 


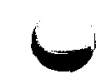




\section{TABLE OF CONTENTS}

Acknowledgements. ................ . . . . .

Conversion Factors. . . . . . . . . . . . . v

Introduction.

CHAPTER I - WASHINGTON'S GEOTHERMAL POTENTIAL . . . . . . I-

CHAPTER II - EXPLORATION. . . ........... II-1

I. Geological Methods. ........... II-2

II. Geochemical Methods ........... . II-4

III. Geophysical Methods ......... . II-5

A. Structural Methods . . . . . . . . II-5

B. Electrical and Electromagnetic Methods . . II-6

C. Passive Seismic Methods. ......... II-6

IV. Exploration Costs ............. . II-7

Selected References. .............. II-8

CHAPTER III - DRILLING. . . . . . . . . . . III-1

I. Drilling Preparation. .......... III-I

A. Road Construction. . ........ . III-3

B. Drill Pad Construction . ......... III-3

C. Drilling Sump Construction ......... III-3

D. Typical Equipment. . . . . . . . . III-3

E. Personnel............. III-4

II. Drilling. ............. III-4

A. Bore Diameter. . . . . . . . . . III-4

B. Rig Types. ............ III-5

C. Directional Drilling .......... III-8

D. Blowout Prevention .......... III-8

III. Post-Drilling . . . . . . . . . . III-10

A. Casing ............. III-10

B. Testing the Well .............. III-11

C. Abondonment. ........... III-11

Selected References. . . . . . . . . . III-13

Geothermal Drilling Rules and Regulations...... . III-14

CHAPTER IV - UTILIZATION. .............. IV-1

I. Electrical Generation ........... IV-1

A. Dry Steam Plants ............ IV-1

B. Flashed Steam Plants .......... IV -4

C. Binary Plants. ........... IV -5

D. Hybrid Plants. ........... IV-7

II. Direct Utilization. . . . . . . . . IV-7

A. Industrial Processing. . . . . . . IV -9

B. Space Conditioning .......... IV-9

C. Agriculture and Aquaculture. ...... IV-12

III. Indirect Utilization............. IV-14

A. Auxiliary Boilers. .......... IV-14

B. Heat Recovery Systems - Heat Pumps .... IV-15

Selected References............... IV-16 
CHAPTER V - ECONOMIC FACTORS OF DIRECT USE PROJECTS . . . V V-1

CHAPTER VI - LEGAL AND INSTITUTIONAL SETTING. . . . . . VII-I

I. Introduction. ........... VI-

II. Obtaining Access to Geothermal Resources. . .... VI-1

A. Determining Resource Ownership ....... VI-1

B. Access and Development Rights. .......VI-2

II. Exploration and Development Regulations ..... VI-11

A. Private Lands. ........... VI-11

B. State Lands. . . . . . . . . . . VI-12

C. Federal Lands. . . . . . . . . . VI-12

D. Washington We11 Permitting Procedures. . . VI-15

E. Geothermal Fluid Disposal. ......... VI-16

F. Water Rights........... VI-16

G. Facility Siting. .......... VI-16

IV. Distribution and Use. ............ VI-16

V. Information, Assistance and Incentives...... VI-17

A. Information Sources. .......... VI-17

B. Technical Assistance ........... VI-19

C. Funding Opportunities. . . . . ..... VI-20

D. Incentives ............. VI-23

Selected References. . . . . . . . . . . VI-25

GLOSSARY. . . . . . . . . . . . . VII-I

APPENDIX 1 - Bibliography Resource Information for the State of Washington, by Michael A. Korosec 


\section{FIGURES}

Figure

Page

1 Geothermal Resources of Washington

xiv

2 Cross Section of a Geothermal System

II- 1

Temperature versus depth for Various Gradients

4a Simplified view of typical drilling sites

I I -4

4b Typical rotary drilling rig and mud circulation

III -2 arrangements

$5 \quad$ Typical blowout prevention equipment

III-9

6 Typical casing program for a production well III-10

7 Direct thermal application of geothermal energy IV-2

8. Dry Steam Power Plant

$9 \quad$ Flash Steam Power Plant

IV -3

IV -4

Double Flash Power Plant

IV -5

Binary Cycle Power PLant

IV -6

Temperatures Required for

IV -8 Geotherma 1 Applications

13 Space Heating and Cooling with Geothermal Fluids Typical downhole heat exchanger installation

IV -9

Typical Heat Convectors and Heat Pump

IV -10

15

Agricultural uses for geothermal resources

IV -11

Heat Recovery System

IV -13

IV -14

Total Annual Costs of Conventional Fuel vs.

V -6 Direct-Use Geothermal

19 Federal Geothermal Regulatory Process

VI-4

Application to Lease Geothermal Resources VI-7

Geothermal Regulatory Process Pre-Lease

VI-9

Activities

22 Federal Geothermal Regulatory Process Principal VI-13 Post-Lease Activities

23 Geothermal Regulatory Process Post-Lease VI-14 Activities 


\section{TABLES}

Table

II

III

IV

V

Costs of Exploration Activities.

Page

II-7

Worldwide Geothermal Electrical Generating Capacity

IV-1

$v-4$

V-7

City Development

V-8 


\section{INTRODUCTION}

\section{The Resource}

Of the earth's total volume of more than one trillion cubic kilometers, all but a relatively thin crust averaging about 30 kilometers thick is very hot. It is believed that the sources of this tremendous amount of heat are radioactivity and friction deep within the earth. In regions where the crust is particularly thin, the heat of the earth may be manifested in hot springs, fumaroles, geysers, and, most dramaticaliy, volcanoes. In recent years the theory of plate tectonics has served as a structure for understanding these phenomena, vital to the successful exploration for and development of the earth's vast geothermal resources.

As with any underground resource, the cost and feasibility of recovery of geothermal energy is directly related its depth. Along the borders of tectonic plates and in zones of crustal extension such as the basin and range provinces of the western United States, the earth's interior heat reaches close to the surface, offering the possibility of economical energy recovery. Perhaps the cost of geothermal energy utilizations is best viewed as a function of the "geothermal gradient", which is the rate at which temperature increases with depth. Where the geothermal gradient is high, temperatures increase rapidly with depth. The average geothermal gradient is about $25^{\circ} \mathrm{C}$ per kilometer.

There are several types of geothermal resources. Virtually all of the world's current utilization involves hydrothermal convection systems, wherein naturally occurring ground water is heated at depth. Systems may be either vapor dominated (steam) or hot water dominated, depending of course on temperature and pressure. - The three essential ingredients of a hydrothermal system are a sufficient heat source, an aquifer with an adequate supply of ground water, and an impermeable stratum overlying the aquifer. Other types of geothermal resources include hot dry rock, which requires the injection of water to be used as a heat transfer medium, and geopressured zones, in which water is trapped together with natural gas under thousands of feet of sediments.

The Uses

Naturally, the use of a geothermal resource depends upon both the nature of the resource itself and the energy demand around it. Utilization is commonly divided into two basic categories; electricity generation, usually requiring temperatures of $150^{\circ} \mathrm{C}$ or more, and direct applications, such as space heating for homes and businesses, applications in agriculture and aquaculture, various industrial process heating uses, and recreational use in pools and hot tubs. An estimated $1800 \mathrm{MW}_{\mathrm{e}}$ (equivalent to roughly 27 million barrels of oil per year) is presently generated in the world, nearly half of which comes from The Geysers in northern California, the United States' only geothermal power generation site. The resource accounts for an additional $7000 \mathrm{MWt}$ on-line worldwide (equivalent to roughly 35 million barrels of 011 per year), only $100 \mathrm{MW}$ thermal of which is in the United States. 
Developing The Resource

Development of a potential geothermal resource involves the coordinated efforts of geologists, economists, and engineers, as well as legal counsel to deal with permitting procedures and environmental regulations. Exploration begins with an analysis of surface expressions such as hot springs and hydrothermal alteration. The next step in defining a resource is detailed geologic mapping (i.e., $1: 24,000$ ). Based on these results, a program of geophysical exploration is devised involving one or several of the following techniques: magnetic, infrared, and gravity surveys; resistivity testing; and active and passive seismic exploration. If the results of this work are encouraging, several relatively shallow (300600 meters) exploratory holes are drilled to measure the geological gradient and heat flow. Finally one or more deep exploration wells are drilled.

The cost of producing electricity with geothermal energy varies considerably according to the resource parameters and the type of generating facility used. Optimally, geothermal power can be produced for as little as $2.5-3 \$ / \mathrm{kwh}$ from dry steam (binary systems cost $4-5 \$ / \mathrm{kwh}$ ) as compared to $6.5 \mathrm{c} / \mathrm{kwh}$ for a coal-fired plant brought on-line in 1984 and 7.3 $\$ /$ kwh for an oil-fired plant operating at 60 percent capacity.

In view of the magnitude of the earth's recoverable geothermal resources, a rapid increase in their utilization is anticipated for the coming years. The mounting concern in America over soaring world oil prices and the health and environmental problems associated with its own vast coal and nuclear reserves, has precipitated a great interest in energy alternatives. Geothermal energy, particularly in the western states, has the potential to contribute significantly to the replacement of those conventional fuels at a cost both economically and environmentally affordable. 


\section{Geothermal Resources of Washington}

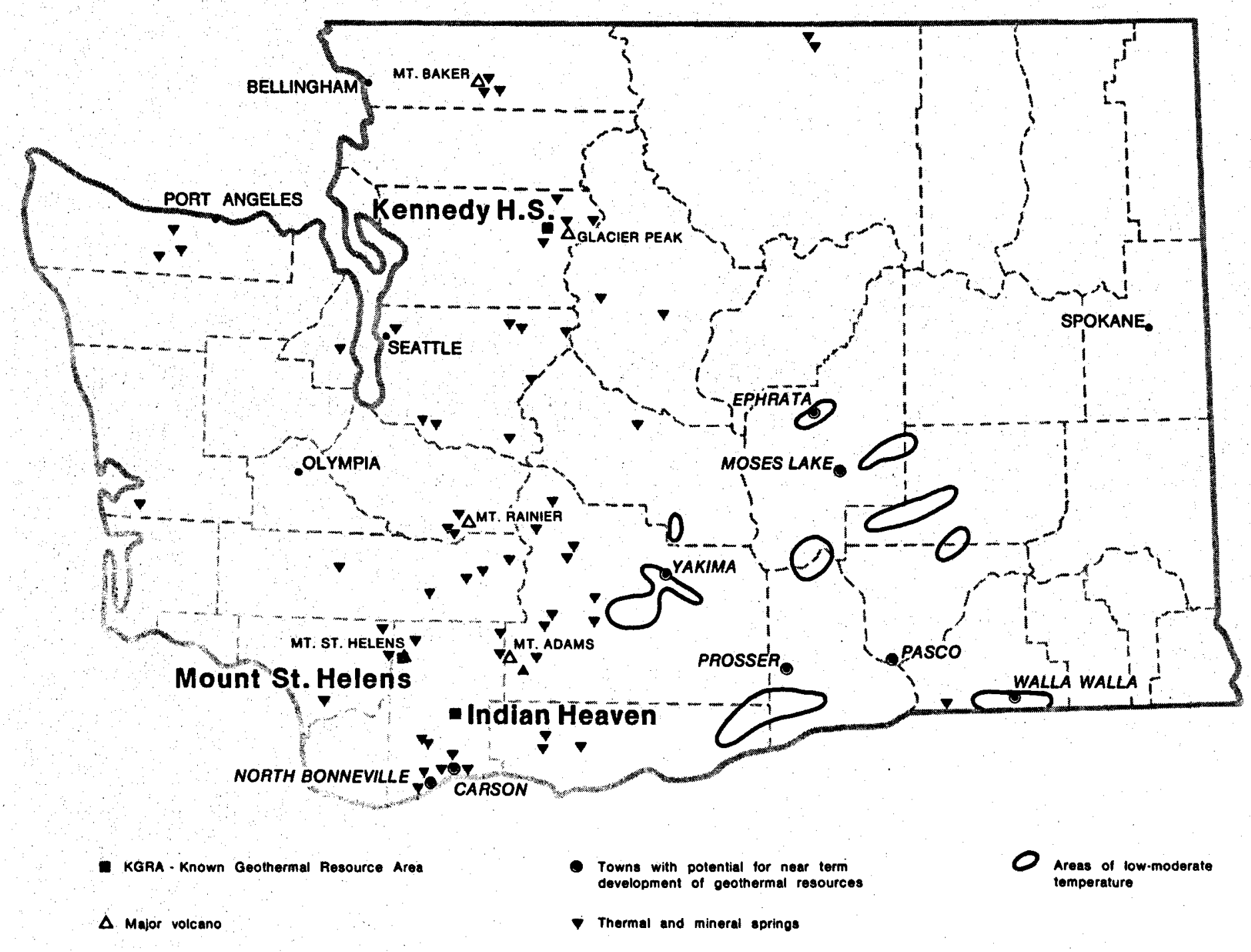

Figure 1 


\section{CHAPTER I}

\section{WASHINGTON'S GEOTHERMAL POTENTIAL}

Geothermal occurrrences in Washington can be divided into three distinct geographic areas: the Cascade Range, the 0lympic Peninsula, and the Columbia Basin.

\section{The Cascade Range}

Of the three areas, the Cascade Range Geothermal Province must be considered to hold the greatest potential as can be seen from the number of thermal and mineral springs and the major stratovolcanoes (Figure 1) (Bloomquist, 1979; Schuster, et al. 1978).

The Cascade Range is topographically dominated by five major andesitic stratovolcanoes. In addition, a series of basaltic volcanic centers are found in the southernn part of the range.

Recent volcanic activity associated with Mount Saint Helens dramatically illustrates that hot rock and magma exist at depth beneath Washington stratovolcanoes. Thermal springs as well as fumarolic activity are additional evidence of the geothermal potential of the Cascades.

The Cascade Range Geothermal Province has received a great deal of attention from potential developers and geothermal lease applications have been filed on over 500,000 acres of U.S. Forest Service lands since 1974. The filing of lease applications has continued to present, with new filings being made almost monthly. In addition, over 30,000 acres have been classified as being in Known Geothermal Resource Areas (KGRAs) by the U.S. Geological Survey. Unfortunately, to date, no leases have been issued nor have any lease sales been held in the KGRAs due to the low priority given geothermal leasing by the U.S. Forest Service (Bloomquist, 1979).

Despite the lack of leasing, industry's interest in the Cascades has increased markedly during the past several months as witnessed by the surge of new lease applications and the number of inquiries concerning the area received by the Washington State Energy office and the Division of Geology and Earth Resources. The most interesting recent development has been the increased interest by developers in direct use applications of geothermal resources.

\section{The Olympic Peninsula}

The 01 ympic Peninsula, al though historically famous geothermaly due to the existence of plush spas at olympic and Sol Duc Hot Springs in the early $1900^{\prime} \mathrm{s}$, must be considered to have little developable geothermal potential.

Both above mentioned spring systems are now found in 01ympic National Park and are protected from exploitation (Bloomquist, 1979).

The U.S. Park Service has, however, expressed interest in utilizing geothermal fluids at Sol Duc Hot Springs Resort for space heating. 
The Columbia Basin

of the three geographic areas, the Columbia Bas in must be considered to be the most exciting in terms of near-term development potential and quite possibly in terms of total exploitable resources.

Large areas in the Columbia Basin (Figure 1) have been identified as having above normal ground water temperatures and above normal geothermal gradients. Ground water temperatures of $18^{\circ} \mathrm{C}\left(65^{\circ} \mathrm{F}\right)$ to $40^{\circ} \mathrm{C}$ $\left(104^{\circ} \mathrm{F}\right)$ are common, as are geothermal gradients above $50^{\circ} \mathrm{C}\left(122^{\circ} \mathrm{F}\right)$ per kilometer (Korosec and Kaler, 1980).

Although these resources are not hot enough to be used directly for industrial processing or space heating, they can be economically utilized by boosting the temperature through the use of heat recovery systems (see Chapter IV, Utilization).

Plans are presently being made to use these low temperature geothermal resources in Ephrata, Yakima, Prosser, Walla Walla, the Tri-Cities, Moses Lake, and several other areas.

Resource Definition

Despite work completed by the Washington Division of Geology and Earth Resources (DGER), the United States Geological Survey (USGS) and serveral university researchers, the aggregate geothermal potential of the state (low, medium, and high temperature) is still poorly defined. However, the resource assessment program in Washington is rapidly acquiring the needed data in order to construct a regional picture of the geothermal potential of the state.

The publication by NOAA of a state geothermal public information map which was prepared jointly by the Washington Division of Geology and Earth Resources and the Geo-Heat Utilization Center of Oregon Institute of Technology (OIT) will provide much needed information concerning Washington's geothermal potential. This map should be available to developers by late fall 1980.

As a result of the prepartion of the public information map, a great deal of information was open-filed by the Washington Division of Geology and Earth Resources and is available for use by developers. The most important reports are: Thermal and Mineral Springs of Washington, We1l Temperature Information for the State of Washington, Heat Flow and Geothermal Gradient Measurements in Washington to 1979, and Bibliography of Geothermal Resource Information for the State of Washington which is included as an appendix to this report. In addition, maps were prepared depicting the status of all geothermal lease applications filed with BLM since 1974. These maps are available for viewing at the Division of Geology and Earth Resource and will be available for purchase by June 1980 from The Washington State Energy Office and the Division of Geology and Earth Resources. 


\section{Continuing Exploration}

The Washington Division of Geology and Earth Resources, through a U.S. Department of Energy sponsored program, will continue to play the leading role in the state geothermal resource assessment program. DGER presently has two full-time geologists involved in this effort. These staff geologists will be responsible for a continuing program of spring identification and sampling, measuring of temperature gradients in existing wells and will initiate the preparation of lineament maps.

The division will also subcontract temperature gradient drilling, gravity measurements, and hydrological and geological studies.

In addition, the USGS is involved in a five year program of regional geothermal assessment in the Cascade Range of Washington, Oregon, and northern California. The state and federal programs are closely coordinated by a board of state and federal officials. 


\section{SELECTED REFERENCES}

Blackwell, D.D., 1980, Heat Flow and Geothermal Gradient Measurements in Washington to 1979: Washington Division of Geology and Earth Resources, Open File Report 80-9.

Bloomquist, R.G., 1979, Geothermal Energy in Washington - Site Data Base and Development Status: Geo-Heat Utilization Center, Oregon Institute of Technology, Klamath Falls, Oregon, $192 \mathrm{p}$.

Campbe11, K.V.; Miers, J.H.; Nichols, B.M.; 01 iphant, J.; Pytlak, S.; Race, R.W.; Shaw, G.H. and Gresens, R.L., 1970, A Survey of thermal springs in Washington State: Northwest Science, v.44, no.1, 11 p.

Coombs, H.A., 1936, The Geology of Mount Rainier National Park: University of Washington, Publications in Geology, v. 3, no. 2, p. 131-212.

Coombs, H.A., 1939, Mount Baker, a Cascade Volcao: Geological Society of America Bulletin, v. 50, no. 10, p. 1493-1509.

Crandell, D.R. and Mullineaux, D.R., 1967, Volcanic Hazards at Mount Rainier, Washington: U.S. Geological Survey Bulletin 1238, 26 p.

Cullins, H., 1977, Known Geothermal Resource Areas (KGRAs) as classified by the area geologist, western and central regions: U.S. Geological Survey, $15 \mathrm{p}$.

Fiske, R.S.; Hopson, C.A. and Waters, A.C., 1963, Geology of Mount Rainier National Park, Washington: U.S. Geological Survey Professional Paper 444, 93 p.

Ford, A.B., 1959, Geology and petrology of the Glacier Peak quadrangle, northern Cascades, Washington: University of Washington, Ph.D. thesis, $374 \mathrm{p}$.

Frank, D,; Meir, M.F. and Swanson, D.A., 1977, Assessment of increased thermal activity at Mount Baker, Washington, March 1975 - March 1976, with contributions by J.W. Babcock, M.0. Fretwell, G.D. Malone, C.L. Rasenfeld, R.L. Shrene, and R.E. Wilcox: U.S. Geological Survey Professional Paper 1022-A, 49 p.

Gizienski, S.F.; McEuen, R.B. and Birkhahn, P.C., 1975, Regional evaluation of the geothermal resource potential in central Washington State: Washington Public Power Supply System, Richland, Washington, Open File Report, $113 \mathrm{p}$.

Hammond, P.E., 1973, Preliminary geologic maps of the southern Cascade Range, Washington: Washington Division of Mines and Geology, Open File Report. 73-3, 5 sheets.

Huntting, M.T.; Bennett, W.A.G.; Livingston, V.E., Jr. and Moen, W.S., 1961, Geologic Map of Washington: Washington Division of Mines and Geology, scale 1:500,000. 
Korosec, M.A., 1980a, Bibliography of Geothermal Resource Information for the State of Washington: Washington Division of Geology and Earth Resources, Open File Report 80-4.

Korosec, M.A. 1980b, Thermal and Mineral Springs of Washington: Washington Division of Geology and Earth Resources, Open File Report 80-8.

Korosec, M.A. and Kaler, K., 1980, Well Temperature Information for the State of Washington: Washington Division of Geology and Earth Resources, Open File Report 80-7.

Korosec, M.A. and McLucas, G., 1980, Quaternary Volcanics in the State of Washington: Washington Division of Geology and Earth Resources, Open File Report 80-6.

Moxham, R.M., 1970, Thermal features of volcanoes in the Cascade Range as observed by aerial infrared surveys: Bulletin Volcanoligique, v.34, no. 1, p. 77-106.

Schuster, J.E.; Blackwe11, D.D.; Hammond, P.E. and Huntting, M.T., 1978 Heat flow studies in the Steamboat Mountain-Lemei Rock area, Skamania County, Washington: Washington Division of Geology and Earth Resources Information Circular 62, $56 \mathrm{p}$. 


\section{CHAPTER II}

\section{EXPLORATION}

At the present time, geothermal exploration is generally focused on areas displaying surface expressions of a geothermal resource, such as geysers, and/or thermal springs (Figure 2). This attention upon surface expression is similar to the course taken by the petroleum industry during the period of initial development at the turn of the century. However, many technologies developed by the petroleum industry now benefit geothermal exploration. These technologies include geophysical, geochemical, or geologic techniques used to determine the location, depth, size, and heat content of a geothermal field.

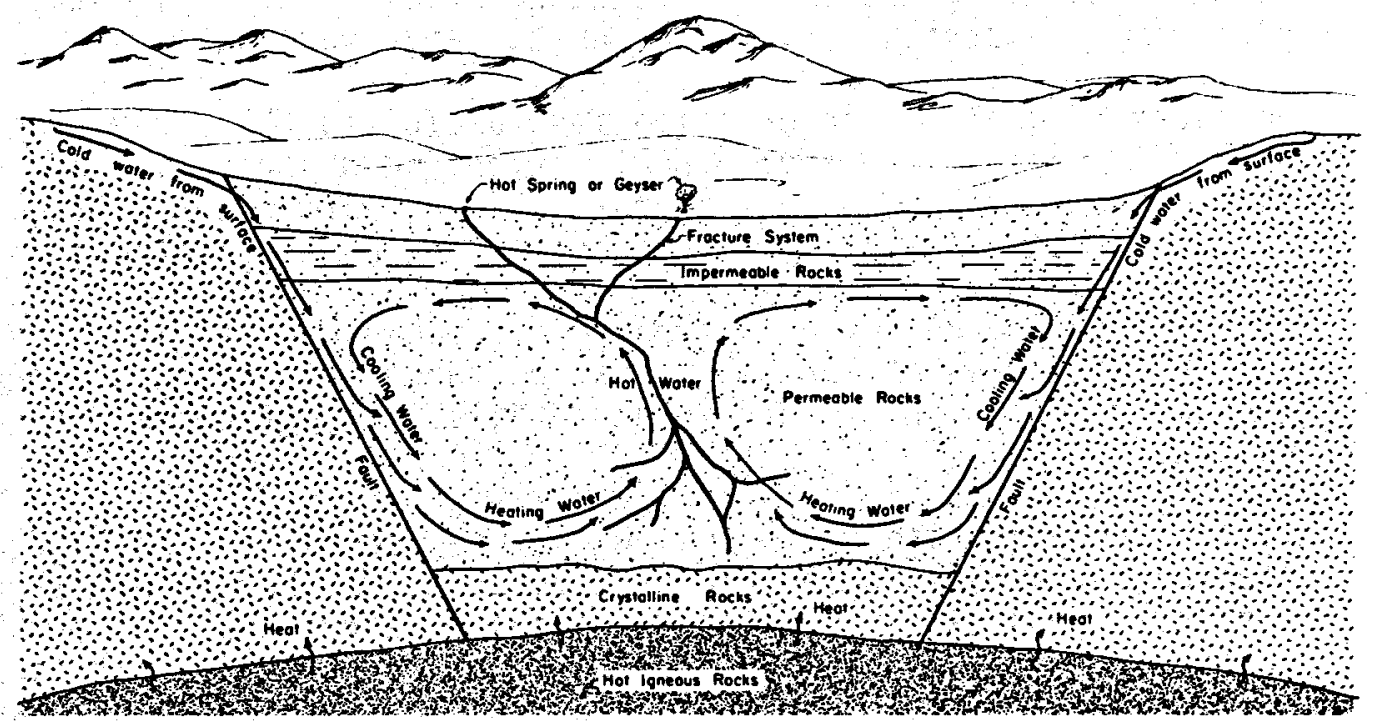

Cross Section of a Geothermal System

Figure 2

The first step for the potential geothermal developer should be a literature search to determine what is already known about a particular area of interest. The research can be divided into two categories: land status and technical information. An evaluation of land status can be made from maps available at the regional office of the Bureau of Land Management (BLM). These maps show land ownership divided into federal (national forest, Indian reservation, military reservation, recreation, and $B L M)$, state, and private lands. More detailed information concerning leasing procedures, permits required, environmental requlations and information on leased lands or lease applications can generally be obtained by contacting the federal land management agency, the state land office, or the state energy office.

Technical information includes both specific geothermal data and general geologic information that may bear indirectly on the nature and occurrence 
of geothermal resources. Specific geothermal information such as locations of thermal springs and warm wells, has been published by the U.S. Geological Survey in two circulars, 726 and 790 (White and Williams, 1975; Muffier, 1979). A nationwide geothermal gradient map has been published by the American Association of Petroleum Geologists (AAPGUSGS, 1976, a,b) and several researchers have published national heat flow maps (for example; Sass, and others, 1976). In addition, the National Oceanographic and Atmospheric Administration has published a geothermal resource map of the Western United States (See Muffler, 1979, Map No. 1). A bibliography of geothermal publications, Geotherma1 Energy Update, is published by the U.S. Department of Energy (DOE), and is updated quarterly. Detailed state geothermal resource maps have either been published or are in preparation and will be available from the state geology offices. The state geology office is a prime source for reports on the geology and geothermal resources of specific areas, and will have information on earthquake studies, geologic structure, volcanology, distribution of rock units, and hydrology.

The types of geologic information most useful in the early stages of geothermal exploration are: The location and distribution of young volcanic rocks, thermal and mineral springs, warm water wells, recent faults, and chemical analyses of thermal and non-thermal waters.

Proximity of the resource to areas of probable use, and the possible conflict with present land uses must be taken into account along with consideration of land ownership and availability of lands for geothermal leasing.

After a thorough literature review has been completed and land status established, a decision should be made as to whether or not a given prospect area shows sufficient potential to warrant spring sampling and geologic reconnaissance mapping. Leasing and intensive site specific exploration would follow. The various geologic, geochemical, and geophysical techniques available for geothermal exploration are designed to produce specific information pertaining to the nature of the resource. Because each geothermal prospect is unique, there is no one method or series of methods which will work in all circumstances. The costs of various methods must be considered in terms of the benefits received and the value of the particular resource. Verification of a geothermal resource can only be accomplished by drilling a well. The following sections briefly describe those methods which can lead to the siting of a deep exploration well.

\section{GEOLOGICAL METHODS}

Geologic studies determine the age, size, and nature of hydrothermal systems and the nature of structural features controlling the location of a potential geothermal reservoir. Geologic techniques include library research, site evaluation, interpretation of well logs, and area geological reconnaissance. A preliminary geologic evaluation can be 
made from information available from the state geology office and the U.S. Geological Survey (USGS) in the form of published maps, reports, unpublished theses, and open-file reports. A geologic map along with aerial photos (also available from the state or USGS) will indicate areas that should be field checked. A study of existing well logs in surrounding areas will give information concerning subsurface structure and rock types. These geologic studies provide a framework for the interpretation of data from the other exploration techniques.

In the field, a general geological reconnaissance indicates areas of volcanic activity, folding, and faulting which may be associated with the geothermal resources. Geologic mapping of the area will determine the structure and potential for finding a suitable porous rock to serve as an aquifer.

Temperature surveys often give valuable information pertaining to the depth of hydrothermal systems and the reservoir's potential temperature.

Two types of temperature surveys have been popular: The 1-meter ground temperature survey and the intermediate-depth survey. The 1-meter survey is rapid and inexpensive if surface conditions permit the construction of survey holes by simple driving techniques. Holes are normally driven to a depth of 1 to 2 meters (3.2-6.4 feet), and the temperatures are measured with a thermistor probe or a bimetallic thermometer. Ground temperature surveys are conducted only in areas where the hydrologic framework is fairly well known. Large, active flows of shallow ground water can completely mask heat flow anomalies from even the largest and most active geotherma 1 sources. To be most effective, ground temperature surveys require near-surface conditions of low permeability with no large flows of fresh water occurring at depth. Al so shallow temperatures can be influenced by seasonal and diurnal temperature changes, vegetative cover, and weather. In these cases, differential measurements may be more accurate. In a differential analysis, the temperatures in the anomalous area are compared to similar measurements made at periodic intervals during the survey, and may also be compared to a reference borehole in an area of displayed activity.

Intermediate-depth surveys are made in holes drilled to depths of 50 meters ( 160 feet) or more. Temperature and gradient measurements, coupled with resistivity data and heat flow calculations may provide all the information necessary for siting deeper exploratory drill holes.

Figure 3 on the following page indicates increased temperature with depth for selected geothermal gradients. 
Temperature $\left({ }^{\circ} \mathrm{F}\right)$

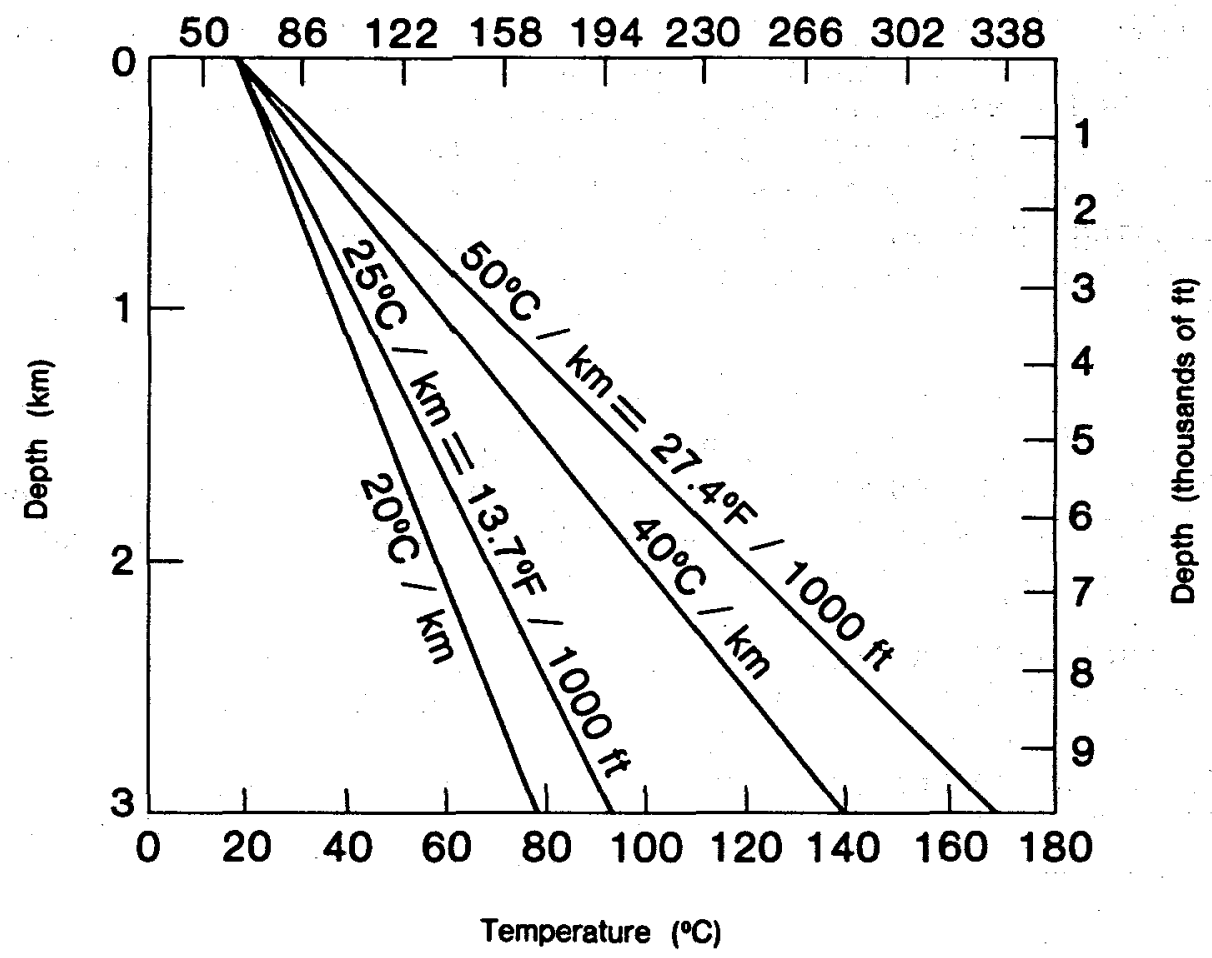

Temperature versus depth for Various Gradients, Ground Temperature Assumed to be $17^{\circ} \mathrm{C}$

Source: Geothermal Handbook, C.S. Leffel, Jr. and R.A. Eisenberg, 1977

\section{GEOCHEMICAL METHODS}

Geochemical investigations involve the sampling of spring systems and the determination of chemical concentrations. Reservoir temperatures calculated from the ionic concentrations of sodium, potassium, calcium, and silica are a valuable indication of actual reservoir temperature. The use of geothermometers, however, requires the making of several assumptions and is thus subject to many uncertainties.

For purposes of geothermometry, it is assumed that certain chemical reactions take place involving the water and the reservoir rock within which the water is held or through which the water passes. The rate of reaction is temperature dependent and, therefore, ionic concentrations in the solute, assumming equilibrium conditions, should be a reflection of temperature. However, the exact reactions which take place are unknown due to several factors. Of these factors, original chemical composition of the water, chemical makeup of the reservoir rock, and length of residence of the water in the reservoir are unknown. Also unknown is the rate at which additional reactions take place as the water rises toward the surface and the degree of mixing that occurs between the hydrothermal fluids and water encountered nearer the surface. Due to the number of unknowns, the accuracy of geochemically estimated 
reservoir temperatures is difficult to assess. Reasonable agreement among the various geothermometers would tend to increase the chance that the estimate is reliable.

Despite the shortcomings of geothermometry and the danger of giving too much credence to any one analysis, geothermometry can and does provide useful information about reservoir temperatures. This is especially true when regional patterns are considered or where spring systems allow for large numbers of related springs to be analyzed.

\section{GEOPHYSICAL METHODS}

A geophysical survey measures variations in the physical properties of the subsurface rocks. These properties include thermal conductivity, electrical resistivity, propagation velocity of elastic waves, density, and magnetic susceptibility. The most distinctive physical properties commonly associated with geothermal systems are high heat flow, low electrical resistivity, and attenuation of high-frequency elastic waves.

The degree of accuracy with which geothermal systems can be detected by geophysical techniques depends on the contrast in the physical properties between the rocks of the geothermal system and the surrounding subsurface.

Geophysical techniques or surveys useful in geothermal exploration can be grouped into three separate categories: Structural methods, electrical and electromagnetic methods, and passive seismic methods.

\section{A. Structura Methods}

Structural methods include active seismic methods (reflection and refraction), gravity surveys, and magnetic surveys. These methods help to refine a regional or local geologic subsurface model.

Active seismic methods involve the use of man-made explosives or surface vibrations to generate elastic waves. The reflection or refraction of these elastic waves off interfaces between rocks of different physical properties can be transmitted to the surface, and the configuration and depth to and/or faults can be calculated.

Gravity surveys, which determine density contrasts of subsurface rocks, have been used both to outline major structural features and to delineate local positive and negative anomalies that may be related to geothermal systems. However, because these anomalies can be produced by factors other than active geothermal systems, gravity surveys are open to gross misinterpretation unless used in conjunction with other exploration techniques.

Magnetic surveys indicate differences in magnetic susceptibility of subsurface rocks, but these surveys are among the least useful in defining a geothermal drilling target. 


\section{B. Electrical and Electromagnetic Methods}

Electrical and electromagnetic methods in geothermal exploration measure the electrical resistivity of rocks at depth. Temperature, porosity, salinity of fluids, and/or content of clays and zeolites tend to be higher within geothermal reservoirs than in the surrounding subsurface. Consequently, the electrical resistivity in geothermal reservoirs is relatively low compared to the host rocks. Therefore these methods could be used, with other data, to delineate a geothermal system.

Many different electrical and electromagnetic methods are used to measure electrical resistivity at depth. The telluric, audiofrequency magnetotelluric (AMT), and magnetotelluric (MT) techniques depend on measuring variations in the natural electrical and magnetic fields of the earth. Other electrical techniques utilize man-made current which enters the subsurface by way of two electrodes with the resultant potential measured at two other electrodes. Electromagnetic methods involve the generation of a magnetic field that varies with time, and the detection of either the electrical or magnetic field arising from currents induced in the earth.

An electrical prospecting technique that has been increasingly used in geothermal exploration is the dipole-dipole array. Although the method is logistically simple and is essentialiy insensitive to rugged topography, effective dipole-dipole investigations require complicated data analysis and are subject to ambiguous interpretation.

The difficulty with interpretation stems from the fact that resistivity is a complicated function of temperature, porosity, salinity, and content of clays and zeolites. For instance, a low temperature, highly saline ground water can provide the same low resistivity anomaly as a high temperature, moderate salinity geothermal system. Therefore, to be most effective, this method should be used in conjunction with direct temperature, geothermal gradient measurements, or other types of data.

\section{Passive Seismic Methods}

Passive seismic methods include the study of microearthquakes which frequently occur in large numbers in known geothermal regions. One mechanism which can generate microearthquakes is excessive fluid pressure resulting from "hot spots". This pressure reduces the effective stress levels and triggers fault slippage. Thus the presence of microearthquakes may be an indicator of a geothermal anomaly at depth. However, not all geothermal areas exhibit microearthquake activity.

Natural occurring ground noise may also be an indication of a geothermal anomaly. Special attention has been given to the investigation of ground noise as a possible prospecting tool.

Other geophysical techniques include the following: 1) Micro-wave techniques; 2) radio frequency interference; 3) aero-magnetics; 4) aerial scanning of infrared radiation. 
IV. EXPLORATION COSTS

The following table shows several exploration methods with approximate times for completion of the surveys and order-of-magnitude costs. It should be stressed that the costs shown are approximate and will vary as a function of many factors including survey detail, accessibility, terrain, and weather. Geothermal gradient and heat flow borehole costs include costs of drilling and completing holes, and well logging. The costs for geochemical procedures include sample collection and chemical analysis. The methods are also characterized as being principally of use in regional and/or detailed evaluations.

TABLE 1

Cost of Exploration Activities

\begin{tabular}{|c|c|c|c|}
\hline Method & Time & Expense & Area \\
\hline Consulting geologist & month & $\$ 200-\$ 400$ day & Regional/detailed \\
\hline Airphoto interpretation & month & $\$ 5 / \mathrm{mile}^{2}$ & Regional/detailed \\
\hline Water analyses & month & $\$ 100-\$ 200 /$ sample & Regional/detailed \\
\hline Surface geochemistry & month & $\$ 30 /$ sample & Detailed \\
\hline Volatile geochemistry & month & $\$ 20 /$ sample & Detailed \\
\hline $\begin{array}{l}\text { Temperature gradient/ } \\
\text { heat flow boreholes }\end{array}$ & month & $\$ 10-\$ 100 / \mathrm{ft}$ & Regional/detailed \\
\hline Electromagnetic methods & month & $\$ 200-\$ 1500 / 1$ ine $\mathrm{mi}$ & Detailed \\
\hline Resistivity & month & $\$ 200-1500 / 1$ ine mi & Detailed \\
\hline $\begin{aligned} \text { Magnetics - airborne } \\
\text { - ground }\end{aligned}$ & $\begin{array}{l}\text { month } \\
\text { month }\end{array}$ & $\begin{array}{l}\$ 25 / 1 \text { ine } \mathrm{mi} \\
\$ 200 / \text { line mi }\end{array}$ & $\begin{array}{l}\text { Regional } \\
\text { Detailed }\end{array}$ \\
\hline $\begin{aligned} \text { Seismic } & \text { - refraction } \\
& \text { - reflection } \\
& \text { - micro- } \\
& \text { earthquakes }\end{aligned}$ & $\begin{array}{l}\text { month } \\
\text { month }\end{array}$ & $\begin{array}{c}\$ 5000 / \text { line mi } \\
\$ 500-\$ 10,000 / \\
\text { line mi }\end{array}$ & $\begin{array}{l}\text { Detailed } \\
\text { Detailed } \\
\text { Regional/detailed }\end{array}$ \\
\hline Gravity & month & $\$ 30-\$ 70 /$ station & Regional/detailed \\
\hline Magnetotellurics & month & $\$ 1200-\$ 2000 /$ line mi & \\
\hline Geophysical logging & week & $\begin{array}{c}\$ 2000-\$ 20,000 / \\
\text { hole }\end{array}$ & Detailed \\
\hline
\end{tabular}

Source: Presentation by Jim Combs for Geothermal Resources Council Short Course \#8. 


\section{SELECTED REFERENCES}

Anderson, D.N., and Lund, J.W., eds., 1979, Direct Utilization of Geothermal Energy - A Technical Handbook: Geothermal Resource Council Special Report No. 7, Davis, Ca.l ifornia.

AAPG-USGS, 1976a, Subsurface Temperature Map of North America: U.S. Geological Survey, Arlington, Virginia.

AAPG-USGS, 1976b, Temperature Gradient Map of North America: U.S. Geological Survey, Arlington, Virginia.

Crosby, J.W., 1971, Geothermal Exploration: A Paper Presented at "The First Northwest Conference on Geothermal Power, "Olympia, Washington, $19 \mathrm{p}$.

Dobrin, M.B., 1976, Introduction to Geophysical Prospecting: McGrawHill Book Company, N.Y., 3rd Edition, 603 p.

Muffler, L.J.P., ed., 1979, Assessment of Geothermal Resources of the United States--1978: U.S. Geological Survey Circ. 790, 163 p.

Sass, J.H., Diment, W.H., Lachenbruch, A.H. and others, 1976, A New Heat-Flow Contour Map of the Conterminous United States: U.S. Geological Survey, Open-File Report 76-756, Menlo Park, California, 24 p.

White, D.E., and Williams, D.L., eds., 1975, Assessment of Geothermal Resources of the United States--1975: U.S. Geological Survey Circ. $726,155 \mathrm{p}$. 


\section{CHAPTER III}

\section{DRILLING}

A principal objective of the exploration phase is to select drilling sites for geothermal production wells. Both the temperature gradient and heat flow holes drilled at the early stages of exploration and deeper test wells drilled during later stages of exploration are considerably smaller and less expensive than production wells.

The drilling of heat flow or temperature gradient holes and the drilling of slim holes or deeper exploration wells often require very little site preparation and are usually drilled from existing roads. In most instances access to drill sites can be accomplished through the use of logging or fire control roads, this is especially true in national forests.

The equipment required consists of a small rotary drill with a depth capability of from $150 \mathrm{~m}$. (500 ft.) to $600 \mathrm{~m}$. (2,000 ft.) and which can drill a $10 \mathrm{~cm}$. (4 in.) to $20 \mathrm{~cm}$. ( 8 in.) diameter hole. Drilling is usually accomplished with an air rotary drill whenever possible, but the drill rig should have the capability of drilling with standard rotary bits including coring and tri-cone bits and using a circulating medium such as mud. Additional equipment consists of a compressor for air drilling, a mud tank and pumps for pumping mud and cement.

Temperature gradient holes or wells and deeper slim holes usually require only surface casing to a depth of from $6 \mathrm{~m}$. $(20 \mathrm{ft}$.) to 30 m. $(100 \mathrm{ft}$.$) .$

Since many geothermal wells are drilled in areas where the resource is relatively shallow (less than $600 \mathrm{~m} .(2,000 \mathrm{ft}$.$) ) and temperatures are$ often below $100^{\circ} \mathrm{C}\left(212^{\circ} \mathrm{F}\right)$ the above mentioned equipment may suffice for the drilling of production wells. However, where drilling for deeper and/or higher temperature resources, the site preparation and drilling equipment become increasingly complex.

Independent of the type of drilling which is to be undertaken, the hiring of a competent drilling contractor and a geological consultant to oversee the operation is a must.

The remainder of this chapter is concerned exclusively with requirements and techniques needed for drilling deeper higher temperature exploration and production wells.

\section{DRILLING PREPARATION}

Drilling preparation consists of buying or leasing the necessary equipment, hiring personnel and preparing a site. The three ma in facets of site preparation may involve road construction, drill pad construction, and mud pit and sump construction. 


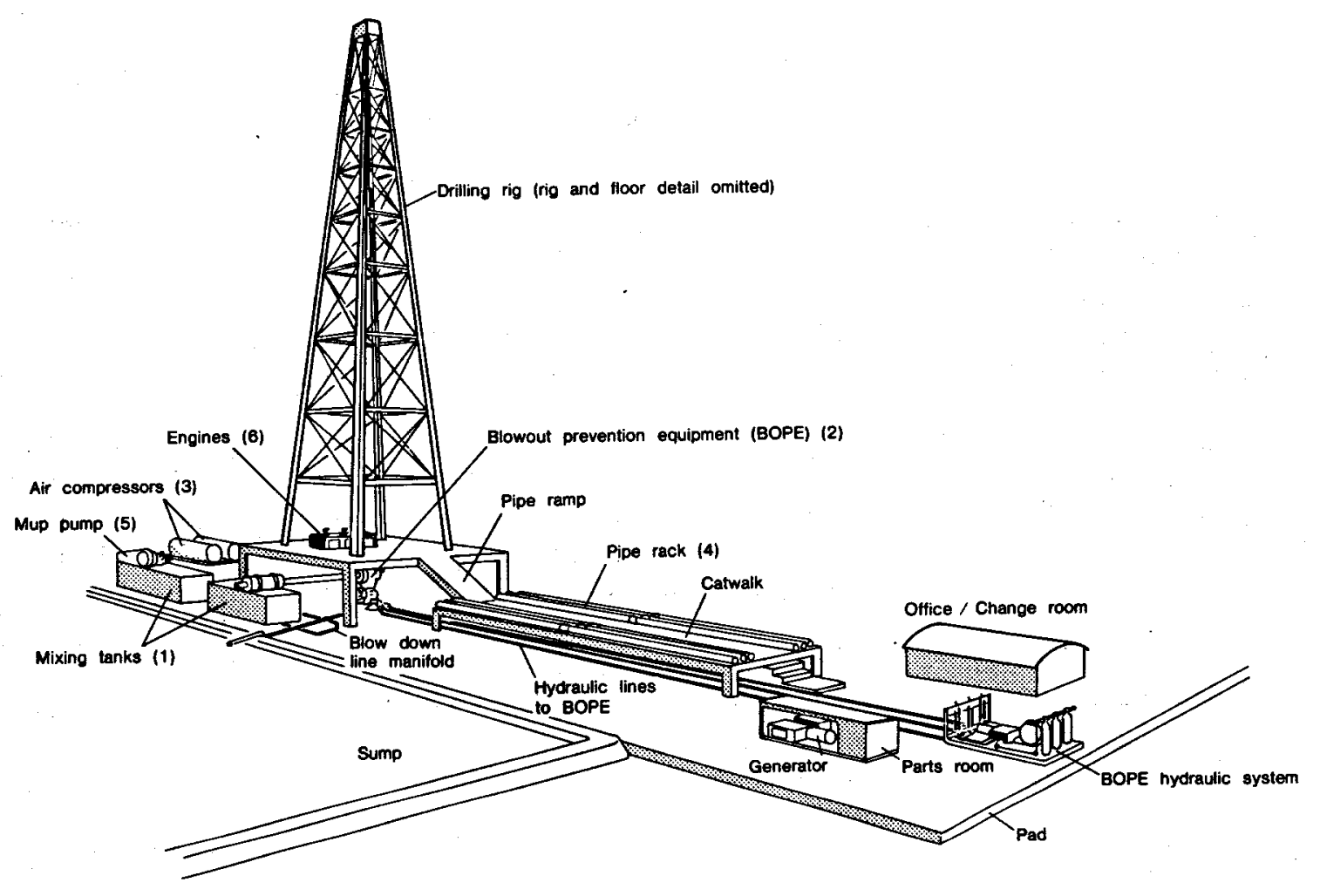

Simplified view of typical drilling site

Figure 4a

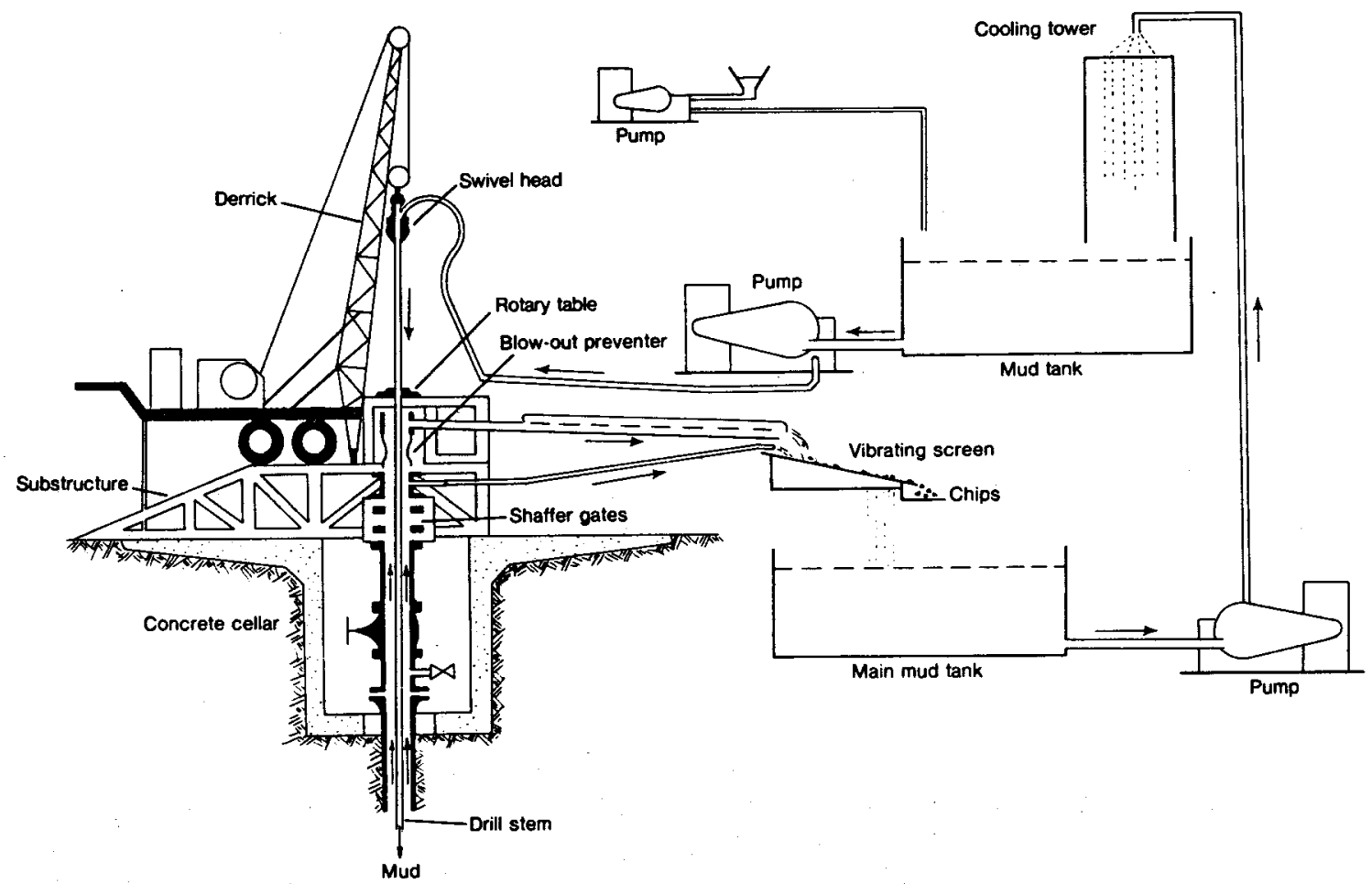

Typical rotary drilling rig and mud circulation arrangements 


\section{A. Road Construction}

In comparison to the temporary roads required for some of the earlier phases of exploration, roads at the drilling stage of development must be designed to carry heavier loads and withstand a more constant traffic burden. Steps to achieve this include surfacing the road with rock, gravel or volcanic cinders or mixing oil with the first $10 \mathrm{~cm} .(4$ in.) of dirt. In hilly terrain, cut and fill construction may be required and a means of controlling surface water runoff must be provided. This can be done by constructing drainage culverts parallel to the road bed and providing drainage conduits where the road "fill" crosses drainage.

\section{B. Drill Pad Construction}

A drill pad is an area which is leveled and cleared of vegetation. The pad must be large enough to accommodate the drilling rig and accessories, temporary structures, and crew parking. Some maneuvering room must be allowed for service and delivery vehicles.

The required surface area, including the reserve pit, generally ranges from less than one acre up to approximately three acres. In hilly regions, pad construction will probably involve cut and fill techniques. Special care must be taken to insure that unstable geologic conditions do not exist and are not created when these techniques are employed. It is sometimes necessary to surface the pad with rock or gravel where vehicle or foot traffic is heavy.

\section{Drilling Sump Construction}

A waste discharge pit, often called a "sump", is required for the containment of waste fluids and drill cuttings. The volume of the drilling sump depends on the anticipated depth of the hole. The surface area can range accordingly from less than a hundred to several thousand square meters, and the depth from 1 to $3 \mathrm{~m}$. (5 to $10 \mathrm{ft}$.) or more. Since the drilling sump is designed to contain fluids, special precautions such as the use of a fine clay sealant (e.g., bentonite) are required to insure impermeability. In all cases, the bottom and sides of the drilling sump will be lined with an impervious material and firmly compacted. In some instances, the drilling sump may be lined with plastic or sealed with gunite or some similar material. The drilling sump is positioned so that when the drilling rig is brought in, the drilling sump will be conveniently located adjacent to the rig. In a developing field, the same drilling sump may be used for drilling several wells.

\section{Typical Equipment}

The largest piece of equipment used during the drilling of an exploratory or development well is the drilling rig, which may be from $10 \mathrm{~m}$. (33 ft.) to $30 \mathrm{~m}$. (100 ft.) high. The actual drilling assembly is composed of a variety of accessories, as shown in in Figures 4 and $4 a$, may include (1) the mixing tanks or mud pit where new drilling mud is mixed with chemicals 
and used drilling mud is stored after being separated from cuttings, blowout prevention equipment, (3) air compressors--for air drilling.

(4) the pipe rack--a horizontal rack for storing of pipe in segments, (5) the mud pumps, (6) engines, and (7) the cooling tower used for cooling the drilling mud during the later stages of deep drilling. Not shown are the fuel tanks, water tanks, and a cyclone separator--used in air drilling of deep holes for separating the cuttings from the circulating medium.

In addition to the machinery and mechanical accessories required to drill a well, there may be a need for a number of temporary structures for which space must be allowed. Among these are the contractor's and operator's trailers which are used as offices, and the logging geologist's trailer.

\section{E. Personnel}

There are two general categories of workers which keep a drilling rig operating; continuing personnel, whose functions require their full time presence and intermittent personnel, whose services are required only at certain stages of the drilling operation.

Intermittent personnel include service personnel, who provide such necessary specialized services as cementing, downhole surveys, formation evaluation tests; and the various inspectors, concerned with compliance with local, state, and federal regulations.

\section{DRILLING}

Ground formations in geothermal areas consist mostly of volcanic rocks, characterized by a high hardness index, a high temperature gradient and which are often faulted and fissured. As a result, losses of circulating fluid are frequent and progress may be much slower than when drilling for $0 i l$ or natural gas.

The time required to drill a well ranges from a few days to 60 days, depending on the depth and diameter of the hole, rock type, drifling method, mechanical problems, weather, supply shortages, etc. Since costs are most directly related to drilling time, decisions as to diameter and drilling methods are crucial to an economically successful drilling operation.

\section{A. Bore Diameter}

It is important that the diameter of a bore be neither too small nor too large. Too small a bore will restrict fluid production by offering a high resistance to its upward flow. On the other hand, too large a bore will require extra time and money to drill. Theoretically there is an optimum bore diameter which is a function of the flow resistance within the bore itself, the flow resistance within the permeable formation from which the bore is fed with fluid, the cost of the bore, the probable success ratio in winning productive wells and the value attached to the geothermal fluid. In practice, this optimum diameter more or less 
defies calculation: It must be chosen in the light of the results from the first few production bores. At first it is advisable to drill bores of rather moderate diameter (e.g., six inches for hot fluid production) and to increase the size if and when the results appear to justify doing so. Although the best choice of bore diameter must to some extent depend upon the "quality" of the fluid.

\section{B. Rig Types}

There are four basic types of geothermal wells: Slim hole/exploratory wells, used mainly for initial geological information in previously unexplored areas, observation wells used only for monitoring the impacts of previously drilled production wells on the geothermal system, injection wells, used to dispose of geothermal waters and maintain pressures in a geothermal reservoir, and production wells, from which geothermal energy is actually extracted.

Each type of well has its own primary objectives, which logically determine the most desirable drilling techniques. For example, exploratory drilling, in constrast to development drilling, should aim for maximum data recovery, essential for evaluation.

Cable tool and rotary drilling are currently the most common methods. Cable tool drilling provides the best bottomhole temperatures, obtained as drilling progresses. Rotary drilling usually involves larger rigs, greater expense, and relatively rapid progress but may yield less reliable temperature data. On the other hand, where preliminary evaluation of a geothermal area is favorable, deep large-diameter holes often demand large rotary drill rigs for production wells.

\section{Cable Tool Drilling}

Cable tooling uses a series of components; sockets, jars, drill stems which weigh from 1,500 to 2,500 pounds attached to a drill bit which drives this combination, called a "drill string" down into the earth. Cuttings and debris are removed by means of a bailer, a chamber with a dart and pop door which traps the cuttings and is then pulled to the surface.

Most cable tool rigs cannot drill deeper than 1,500 feet. However, some can penetrate to depths of up to 6,000 feet. The major problem of cable drilling is the limited capacity of different types of equipment to hoist the weight of the drill string and cable.

Cable tool rigs, however, are often available for drilling water wells and are completely satisfactory where high temperatures (above $100^{\circ} \mathrm{C}\left(212^{\circ} \mathrm{F}\right)$ ) are not expected.

\section{Rotary Drilling}

Rotary rigs use a spinning drill stem with a bit attached to the bottom. The drill stem is hollow, so that the drilling medium (mud, air, foam, or water) may pass through it. As drilling proceeds, it is not uncommon to switch media in response to temperature and pressure changes in the hole. 
Most rotary rigs are diesel powered. Power is required to turn the drill stem, to run the compressors, and pulley arrangements for lowering and raising the stem in the hole, and to pump the drilling mediums into the hole and back out into cooling, settling, and storage ponds.

a. Drilling With Mud

The drilling mud is pumped down through the drill pipe, exits through "jets" in the drill bit and travels back up the annular space between the drill pipe and the hole, carrying the cuttings up with it. The mud has several important functions. It cools and lubricates the bit, helps break up the rock, its weight helps keep formation pressures under control, and it brings the cuttings to the surface with a minimum of mixing or settling. This latter function enables the logging geologist to correlate the cuttings with depth, and thus determine the type of rock being cut. The mud also forms a wall cake on the inside of the hole and helps prevent the hole from sloughing in. If high temperatures are encountered, $200^{\circ} \mathrm{C}\left(424^{\circ} \mathrm{F}\right)$, drilling mud can "bake", becoming useless. By changing over to air drilling, this problem can be circumvented. High bottomhole temperature gellation of muds has been avoided by employing special mud systems, such as sepio lite mud, which withstands higher temperatures than conventional muds.

With the drill bit turning on bottom and the drilling fluid in circulation, the drilling team is said to be "making hole." Shallow formations usually drill rapidly. Generally, surface casing is set and cemented before the harder, deep drilling is begun. Surface casing provides a support for attachment of the blowout preventers and related equipment, and maintains the hole through the shallow unconsolidated formations.

During routine drilling, the crew must add sections of drill pipe, as drilling progresses until the bit is worn out and must be replaced. Drill bit life varies greatly with the type of bit and type of formation being penetrated.

Changing the bit is accomplished in an operation called "making a trip," in which the drill pipe is removed from the hole in "stands" which are stacked in a vertical position on the derick floor. When the drill bit has been changed the trip continues until the bit is on bottom and drilling can be resumed.

b. Drilling With Air

During the drilling, the temperature of the drilling fluid is monitored as it enteres and exits the hole. As temperature increases begin to cause the mud breakdown, the driller may switch to air, water, or foam as the circulation medium. 
With air or foam as a circulating medium, the same basic functions are fulfilled as with the mud, with a few exceptions. There is effectively very little weight to the column of air, so it does not control formation pressures. Another difference between air and mud as drilling media is that while mud seals ground water from the hole, desirable in the upper portions, the use of air as a circulating medium avoids sealing off the lower portion of the hole, which would reduce the flow of. hydrothermal fluids when encountered. When properly applied, air drilling can result in faster penetration rates, longer bit life, better control through lost circulation zones and efficient completion techniques in low-pressure vapor-dominated geothermal reservoirs.

A common practice is to use mud until nearing the production zone, and to use air drilling when penetrating the production zone, thus avoiding sealing of that zone by the mud.

Drilling with air requires much greater velocities to lift the cuttings than does drilling with viscous mud. Sand particles in the air stream are highly erosive and effectively sandblast the drill pipe assembly and the casing. During air drilling, noise levels, if unchecked, may approach 125 bd; however, . muffler systems currently in use are designed to reduce the noise to within federal limits.

Air is an attractive fluid for drilling into competent reservoirs because it will not damage the formations and generally improves rate of penetration. However, air drilling does cause rapid erosion of downhole equipment. At The Geysers, where a special anti-erosion additive is used in the air stream, it is still necessary to junk one foot of drill pipe per seven feet of hole. This naturally requires extra services and supplies. Furthermore, completion problems can arise for those wells which produce wet steam because it can erode casing as the high speed fluid strips water film from the casing surface requiring higher quality casing with flush joints to reduce the problem.

c. Drilling With Water

Many geothermal well drillers are now drilling primarily with water, using mud only in zones where there is difficulty holding the formation. Drilling with water prevents the plugging of permeable producing zones and fractures and keeps the fluid column light enough so that geothermal water can enter the hole. It is the only recommended drilling method for resources of moderate temperatures and low artesian pressures.

3. Turbo-Drilling

With conventional rotary drilling the mechanical power drive is placed at the ground surface and the driving torque is transmitted to the bit through the long drill-stem. In very deep holes this 
driving torque may cause two or three complete rotations of the stem, so that the bit lags behind the drive by several hundred degress of angle, causing damage to the casing and unlined bore walls. Various attempts have therefore been made to fix the driving unit at the base of the hole, close to the bit, so that the stem--though still twisted by the torque--need rotate at a very low rate. The turbo-drill makes for improved penetration rates and easy adaptability to directional drilling. The cost of using the turbo-drill at various depths is comparable to that of conventional drilling.

\section{Directional Drilling}

The directional or deviated hole is a hole drilled at an angle or series of angles to reach a bottom hole location other than directly beneath the rig. It is used when made necessary by unstable surface conditions, access problems, or the presence of an immovable object directly above the desired bottom hole location. The directional hole may also be used to drill to more than one subsurface location from a single surface location (especially common in offshore oil drilling), thus economizing on surface pipework and land acquisition costs. Directional drilling may entail angels of up to $85^{\circ}$ in ideal conditions, such as in poorly compacted sediments with little faulting and simple geologic structures. However, geothermal resources often occur in hard metamorphic or igneous rock in typically faulted, complex structures. Under these conditions, control is extremely difficult to maintain and directional drilling is avoided whenever possible.

The directional hole costs on the average one and one-half times as much as the straight hole. The added costs are incurred through directional drilling equipment services, difficulties such as maintaining the angle and bearing of the hole, maintaining good return of cuttings, and equipment failure. In view of these special costs and the difficulties in directional drilling, it is avoided whenever possible.

\section{Blowout Prevention}

When the pressure within a penetrated formation exceeds the pressure exerted by the column of fluid or air in the drill hole, the well may blow out. If this occurs in a geothermal well, the effiuents will consist of steam and/or hot water with dissolved salts and possibly noncondensible gases such as hydrogen sulfide, carbon dioxide or ammonia. The primary danger is to operating personnel, who could suffer burns from steam or water and injury from falling objects. In some cases a hazard due to hydrogen sulfide may result.

A secondary impact would be the unchecked flow of toxic gases or water to the surface, resulting in air and water pollution. The blowout may also create excessive noise. Should a blowout continue unabated, sand, gravel, and rock fragments may erode the surface material from under the drilling platform, enlarging the hole to form a crater, into which the rig itself may collapsë.

Controls must be installed on the casing to prevent such an occurrence whenever high temperature, high pressure wells are drilled. Necessary blowout prevention equipment depends upon the area being drilled, depth 
of the well, expected pressures, and past drilling experience in the area. The equipment consists essentially of one or more of the following three items: Annular preventer, a device which may be compressed to close the annular space between casing and drill pipe; pipe ram, a ram with an opening of a size to close around the drill pipe; blind, blank, or complete shut-off ram, a ram which is used on an open hole when there is no drill pipe in the hole.

The blowout prevention equipment and attendant fittings are installed on top of the casing (Figure 5). Proper use of these controls will prevent blowouts and resulting adverse effects on the environment that could be caused.

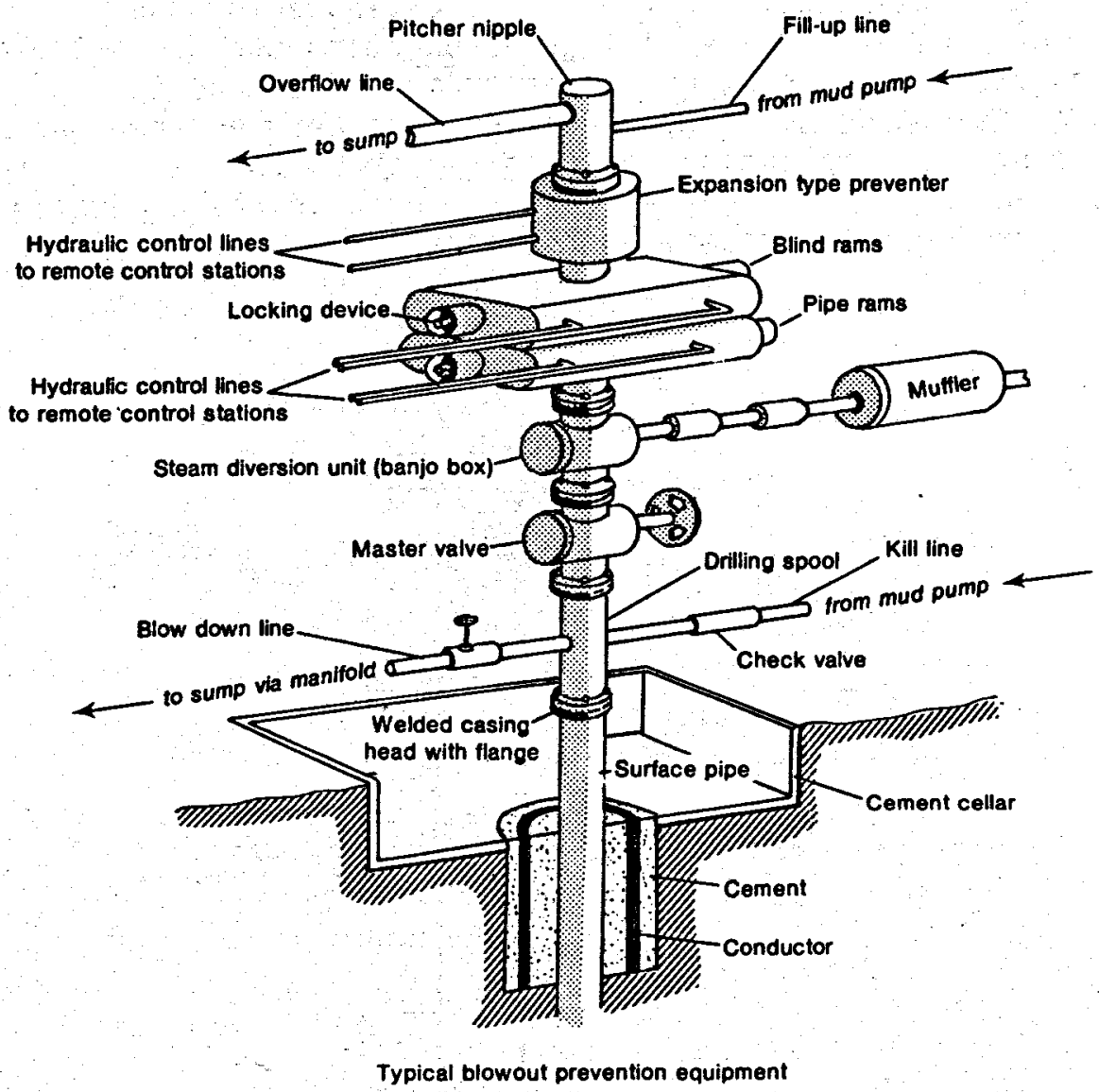

Figure 5

Usually, the blowout prevention equipment is inspected and pressure tested at least once on each string of casing by personnel of a federal, state, or local regulatory agency. The equipment is inspected daily by operating personnel, and is pressure-tested at least once a week and following all repairs. During drilling operations, the rams, both blind and pipe, are operated once each time the drill pipe is removed from the hole and the expansion type preventer once each week. 


\section{POST-DRILLING}

\section{A. Casing}

"Casing" refers to the lining of the well with concrete, pipe or screening for structural support and sealing. Both production and exploratory wells must be cased during drilling to prevent collapse of the hole and to maintain zone and aquifer separation.

There are five basic types of casing:

Conductor pipe is the first and largest diameter string of casing to be installed, extending from the surface to a minimum of 40 feet. Intermediate string of casing is the casing installed in order to seal out nongeothermal water producing zones, and to prevent caving below the bottom of the conductor pipe or surface casing. Production string is the casing that extends from the production zone to the surface and through which the resource is produced. Surface casing runs between the conductor pipe and the blowout prevention equipment in order to seal out ground water zones. Screen or perforated casing is used in the production zone to prevent caving without sealing the zone.

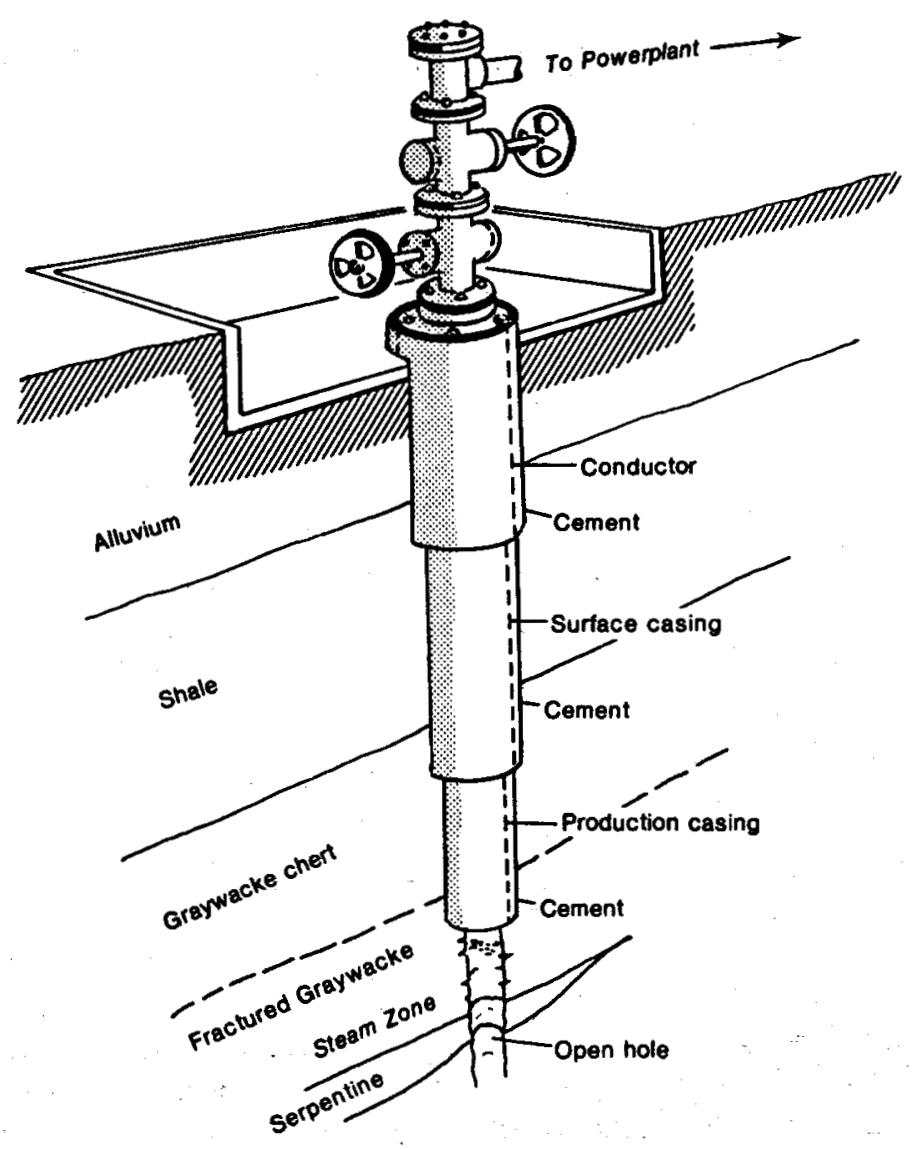

Typical casing program for a production well 
The casing program which is selected will depend upon the geology (i.e., hard rock or loosely consolidated sediments) and type of geothermal system. The casing program of an exploratory or production well will generaily consist of the following for any area: Conductor set to $15 \mathrm{~m}$. (50 ft.) surface casing to $\pm 60 \mathrm{~m}$. (200 ft.), primarily to provide an anchor for blowout equipment, and a string of production casing. Sometimes an intermediate casing is used between the surface casing and the string of production casing to protect interlying zones. For hard rock areas such as The Geysers in California, the final portion of the well is open hole below the intermediate casing (Figure 6). For areas with loosely consolidated sediments such as Salton Sea in California, slotted liner is required in the lower portion to control sand flow. An effective casing program will prevent significant environmental impact. If done improperly, geothermal fluids may leak from the producing zone to overlying aquifers, or even to the surface.

The corrosion of casing is nearly always caused by hydrogen sulfide and other acids. Formations yielding water of low $\mathrm{pH}$ value, as determined by sampling during the drilling of the well, should be cemented off.

\section{B. Testing The Well}

Upon completion of drilling, the geothermal well is tested for production by pumping the well and by gauging the volumes and temperatures of geothermal fluids. Flow to the surface is usually directed into the drilling sump, which is used as a test sump. Federal regulations do not allow the use of evaporating ponds or existing water bodies. The impact from testing is from noxious gases and toxic elements such as arsenic and boron in the geothermal water. The gases, if occurring in quantity, are removed, and the toxic elements are contained within the sump or in a portable tank. During testing of a steam well venting is done through a system of mufflers so that noise does not rise above ambient levels at a distance of about $.8 \mathrm{~km}$ (one-half mile).

Measurements are made on wellhead pressure, enthalpy, mass flow, rates of change of mass flow, ionic concentrations, total constituents analyses, etc. Geothermal fluid not flashed to steam must be stored on the site or discharged to the surface drainage system. Injection is usually not possible at this time, as two wells are required, along with a more complete knowledge of the resource. In addition to the testing, a well may be pumped or allowed to flow for several days to clean the hole of any material which may interfere with production.

\section{Abandonment}

If a well is not productive, or becomes noncommercial due to corrosion, ebbing production, or other causes, it may be abandoned. Plugging and abandonment of a well must comply with federal, state, and local environmental regulations. Like virtually all of the steps in well drilling, requirements for abandonment vary according to the type of hole drilled, depth, formations encountered, and other factors.

Generally, the simplest abandonment requirements are for shallow (less than $150 \mathrm{~m}$. or $500 \mathrm{ft}$.) temperature gradient holes. These wells are 
filled with drilling mud to a depth of $3 \mathrm{~m} .(10 \mathrm{ft}$.$) and with a cement$ plug from $3 \mathrm{~m}$. (10 ft.) to the surface or with cement from total depth to surface, depending on the character of fluids encountered.

As a rule, exploratory or production wells are deeper and more complex, requiring correspondingly more plugs. The number of plugs required generally increases with the depth, the complexity of the regional geology, the complexity of the well, the material left in the hole such as twisted-off drill pipe, and other conditions. The intent is to prevent the movement of fluids in the well bore so that there is no movement between aquifers and no flow to the surface. Portions of the well bore not filled with cement are filled with drilling mud. Once all plugs have been set, the casing is cut off at least $2 \mathrm{~m}$. (6 ft.) below. the ground surface and capped by welding on a steel plate. Collars, pads and all other structures are removed and the surface area returned to the original grade. All remaining refuse must be removed from the area and the site reclaimed or revegetated to the specifications of the surface managing agency. 


\section{SELECTED REFERENCES}

Armstead, H.C.H., 1978, Geothermal Energy: Halstead Press, John Wiley and Sons, New York, p. 71-87.

Bammerman, J.K.; Davis, N.; and Wolke, R., 1978, Geothermal Drilling Fluid Systems: in Geothermal Resources Council Transactions, v. 2, p. 27-29.

Idaho Geothermal Handbook: 1979, published by the Idaho Office of Energy, p. 36-42.

Geothermal, Energy: 1975, Informatics, Inc. November 1975, p. 100-102.

Matsuno, K., 1973, Drilling for Geothermal Steam and Hot Water: in Geothermal Energy, p. 73-83 (Earth Science, 12).

Miller, L.G.; Prestwich S.M.; and Gould, R.W., 1978, Drilling and Directional Drilling a Moderate-Temperature Geothermal Resource: in Geothermal Resources Council, Transcations, v. 2, p. 455-456.

Raschen, R. and Cook, W.S., 1976, Exploration and Development of Geothermal Resources: U.S. Geological Survey, September 1976, p. 8-15.

Geothermal, Handbook: 1976, U.S. Department of Interior, U.S. Fish and Wildlife Service, p. 144-158.

Vernado, S.G. and Stroller, H.M., 1978, Geothermal Drilling and Completion Technology Development: in Geothermal Resources Council, Transactions, v. 2, p. $675-678$. 
Chapter 332-17 WAC

GEOTHERMAL DRILLING RULES AND REGULATIONS

\section{NEW SECTION}

WAC 332-17-010 INSPECTION. The department shall inspect all geothermal operations for the purpose of obtaining compliance with the rules, regulations, and orders promulgated by authority of the Geothermal Resources Act, chapter 43, Laws of 1974 ex. sess.

\section{NEW SECTION}

WAC 332-17-020 GENERAL RULES. General rules shall be statewide in application unless otherwise specifically stated and shall be applicable to all lands within the jurisdiction of the state of Washington.

\section{NEW SECTION}

WAC 332-17-030 SUPREMACY OF SPECIAL RULES AND ORDERS. Special rules and orders will be issued as required and shall prevail as against general rules if in conflict therewith.

\section{NEW SECTION}

WAC 332-17-100 APPLICATION FOR PERMIT TO COMMENCE DRILLING, REDRILLING OR DEEPENING. (1) The owner or operator of any well, or proposed well, before commencing the drilling, redrilling, or deepening of any wells shall file with the department a written application in triplicate of the intention to commence such drilling, redrilling or deepening accompanied by a fee of two hundred dollars as prescribed in RCW 79.76.070, except no fee is required for the drilling of core holes. The application shalt be on forms as prescribed by the department and contain the following:

(a) The name of operator or company and address.

(b) Description of the lease or property including acres together with the name and address of the owner or owners of surface and mineral rights.

(c) The proposed location of the well or wells including a typical layout showing the position of mud tanks, reserve pits, cooling towers, pipe racks, etc.

(d) Existing and planned access and lateral roads.

(e) Location and source of water supply and road building material.

(f) Location of supporting facilities. 
(g) Other areas of potential surface disturbances.

(h) The topographic features of the land, including drainage patterns.

(i) Methods for disposing of waste materials.

(j) The proposed drilling and casing plan.

(k) A surveyed plat showing the surface and expected bottom-hole locations and the distances from the nearest section or tract lines as shown on the official plat of survey or protracted surveys of each well or wells. The scale shall not be less than 1:24,000.

(1) A narrative statement describing the proposed measures to be taken for protection of the environment, including, but not limited to, the prevention or control of:

(i) Fires,

(ii) soil erosion,

(iii) pollution of surface and ground waters,

(iv) damage to fish and wildlife or other natural resources,

(v) air and noise pollution, and activities.

(vi) hazards to public health and safety during operational

(m) Such other pertinent information or data which the department may require to support the application for the development of geothermal resources and the protection of the environment.

Provisions for monitoring may be required as deemed necessary by the department to ensure compliance with these regulations.

The collection of data concerning existing air and water quality, noise, seismic and land subsidence activities, and the ecological system of the area may be required as deemed necessary by the department.

(2) An application for the drilling of core holes shall contain the following:

(a) Name and address of the operator or company.

(b) Name and number, location of the core hole or holes to the nearest quarter-quarter section or lot.

(c) Proposed depth of each core hole, but not to exceed 750 feet into bedrock.

(d) A map of sufficient scale to show topography and drainage patterns, access roads, and the proposed core hole locations. A metes and bounds description of each core hole location shall be provided to the department within thrity days of completion of the core hole or the approved core hole program.

(3) Well names and numbers shall not be changed without first obtaining the written approval of the department.

\section{NEW SECTION}

WAC 332-17-110 CASING REQUIREMENTS. (1) A11 wel1s shall be cased to protect or minimize damage to the environment, surface and ground waters, geothermal resources and health and property. The department shall approve proposed well spacing and well casing programs or prescribe such modifications to the programs as the department determines necessary for proper development, giving consideration to such factors as: 
(a) Topographic characteristics of the area.

(b) Hydrologic, geologic, or reservoir characteristics of the area.

(c) The number of wells that can be economically drilled to provide the necessary volume of geothermal resources for the intended use.

(d) Protection of correlative rights.

(e) Minimizing well interference.

(f) Unreasonable interference with multiple use of lands.

(g) Protection of the environment.

(2) Casing specifications shall be established on an individual well basis. The following specifications are general, but should be used as guidelines in submitting drilling permit applications.

(a) Conductor pipe. Annular space shall be cemented solid from the shoe to surface. An annular blowout preventer, or equivalent, remotely controlled hydraulically operated including a drilling spool with side outlets or equivalent may be required by the department $A$ kill line and blowdown line with appropriate fittings shall be connected to the drilling spool when same is required. feet).

Conductor casing shall be set to a minimum depth of 15 meters ( 50

(b) Surface casing. This casing shall be set at a depth equivalent to, or in excess of, ten percent of the proposed depth of the well, provided, however, such depth shall not be less than 60 meters (200 feet) or extend less than 30 meters (100 feet) into bedrock. Surface casing holes shall be logged with an induction electric log, or equivalent, prior to running surface casing.

(c) Intermediate casing. This casing shall be required whenever anomalous pressure zones, cave-ins, washouts, abnormal temperature zones, uncased fresh water aquifers, uncontrollable lost circulation zones, or other drilling hazards are present or occur, and whenever the surface casing has not been cemented through competent rock units.

Intermediate casing strings shall be cemented solid if possible from the shoe to surface. If a liner is used as an intermediate string, the lap shall be tested by a fluid entry or pressure test to determine whether a seal between the liner top and the next casing string has been achieved. The liner overlap shall be a minimum of 30 meters (100 feet). The test shall be recorded in the driller's $10 \mathrm{~g}$ and may be witnessed by a representative of the department.

(d) Production casing. This casing may be set above or through the producing or injection zone and cemented above the objective zones. Production casings shall be cemented to the surface or lapped into the intermediate string. Overlap shall not be less than 30 meters $(100$ feet) and shall be pressure tested. Lap or casing failure shall require repair, recementing, and successful retesting.

(e) Cementing of casing. Conductor and surface casing strings shall be cemented with a quantity of cement sufficient to fill the annular space from the shoe to surface. A high temperature resistant admix shall be used in cementing production casing unless waived by the department, and shall be cemented in a manner necessary to exclude, isolate, or segregate overlying formation fluids from the geothermal resources zone and to prevent the movement of fluids into possible fresh water zones.

A temperature or cement bond log may be required by the department if an unsatisfactory cementing job is indicated. 
(f) Pressure testing. Prior to drilling out the casing shoe after cementing, a 11 casing strings set to a depth of 152 meters ( 500 feet) or less except for conductor casing, shall be pressure tested to a minimum pressure of 35 bars ( $500 \mathrm{psi}$ ). Casing strings set to a depth of 152 meters (500 feet) or greater shall be pressure tested to a minimum pressure of 69 bars $(1,000 \mathrm{psi})$ or $0.045 \mathrm{bars} / \mathrm{meter}(0.2 \mathrm{psi} / \mathrm{ft})$ whichever is greater. Such test shall not exceed the rated working pressure of the casing or the blowout preventor stack assembly, whichever is lesser.

\section{NEW SECTION}

WAC 332-17-120 BLOWOUT PREVENTION. Blowout prevention and related control equipment shall be installed, tested immediately thereafter, and properly maintained ready for use until drilling operations are completed. Certain components, such as packing elements and ram rubbers, shall be of high temperature resistant material as necessary. All kill lines, blowdown lines, manifolds, and fittings shall be steel and have temperature derated minimum working pressure rating equivalent to the maximum anticipated wellhead surface pressure. Unless otherwise specified, blowout prevention equipment shall have manually operated gates and remotely controlled hydraulic actuating systems and accumulators of sufficient capacity to close all of the hydraulically operated equipment and have a minimum pressure of 69 bars (1,000 psi) remaining on the accumulator. Dual control stations shall be installed with a high pressure backup system. One control panel shall be located at the driller's station and one control panel shall be located on the ground at least 15 meters ( 50 feet) away from the well head or rotary table. Blowout prevention assemblies involving the use of air or other gaseous fluid drilling systems may include, but are not limited to, a rotating head, a double ram blowout preventor or equivalent, a banjo-box or an approved substitute therefore and a bl ind ram blowout preventer or gate valve, respectively. Exceptions to the requirements of this paragraph will be considered by the department for areas of known surface stabil- : ity and low subsurface formation pressure and temperatures.

(1) Conductor casing. One remotely controled hydraulically operated expansion type preventer or acceptable alternative, including a drilling spool with side outlets or equivalent, may be required before drilling below conductor casing.

(2) Surface, intermediate and production casing. Prior to drilling below any of these strings, blowout prevention equipment shall include a minimum of: head,

(a) One expansion-type preventer and accumulator or a rotating

(b) A manual and remotely controlled hydraulically operated double ram blowout preventer or equivalent having a temperature derated minimum working pressure rating which exceeds the maximum anticipated surface pressure at the anticipated reservoir fluid temperature,

(c) A drilling spool with side outlets or equivalent,

(d) A fillup line,

(e) A kill line equipped with at least one valve and

(f) A blowdown line equipped with at least two valves and securely anchored at all bends and at the end. 
(3) Testing and maintenance. Ram-type blowout preventers and auxiliary equipment shall be tested to a minimum of 69 bars (1,000 psi) or to the working pressure of the casing or assembly, whichever is the lesser. Expansion-type blowout preventers shall be tested to 70 percent of the above pressure testing requirements.

(a) The blowout prevention equipment shall be pressure tested:

(i) When installed,

(ii) Prior to drilling out plugs and/or casing shoes,

(iii) Not less than once each week, alternative the control stations, and

(iv) Following repairs that require disconnecting a pressure seal in the assembly.

(b) During drilling operations, blowout prevention equipment shall be actuated to test proper functioning as follows:

(i) Once each trip for blind and pipe rams, but not less thanonce each day for pipe rams, and

(ii) At least once each week on the dri11 pipe for expansion-type preventers.

All flange bolts shall be inspected at least weekly and retightened as necessary during drilling operations. The auxiliary control systems shall be inspected daily to check the mechanical condition and effectiveness and to ensure personnel acquaintance with the method of operation. Blowout prevention and auxiliary control equipment shall be cleaned, inspected and repaired, if necessary, prior to installation to assure proper functioning. Blowout prevention controls shall be plainly labeled, and all crew members shall be instructed on the function and operation of such equipment. A blowout prevention drill shall be conducted weekly for each drilling crew. All blowout prevention tests and crew drills shall be recorded on the driller's log.

(4) Related well control equipment. A full opening drill string safety valve in the open position shall be maintained on the rig floor at all times while drilling operations are being conducted. A keliy cock shall be installed between the kelly and the swivel.

\section{NEW SECTION}

WAC 332-17-130 DRILLING FLUID. The properties, use and testing of drilling fluids and the conduct of related drilling procedures shall be such as are necessary to prevent the blowout of any well. Sufficient drilling fluid materials to ensure well control shall be maintained in the field area readily accessible for use at all times.

(1) Drilling fluid control. Before pulling drill pipe, the drilling fluid shall be properly conditioned or displaced. The hole shall be kept reasonably full at all times, however, in no event shall the annular mud level be deeper than 30 meters (100 feet) from the rotary table when coming out of the hole with drill pipe. Mud cooling techniques shall be utilized with necessary to maintain mud characteristics for proper well control and hole conditioning. The conditions contained herein shall not apply when drilling with air or aerated fluids.

(2) Drilling fluid testing. "Mud testing and treatment consistent with good operating practice shal1 be' performed daily or more frequently 
as conditions warrant. Mud testing equipment shall be maintained on the drilling rig at all times. The following drilling fluid system monitoring or recording devices shall be installed and operated continuously during drilling operations, with mud, occurring below the shoe of the conductor casing:

(a) High-low level mud pit indicator including a visual and audiowarning device, if applicable,

(b) Degassers if applicable, and desilters and desanders if required for solids control,

(c) A mechanical, electrical, or manual surface drilling fluid temperature monitoring device. The temperature of the drilling fluid going into and coming out of the hole shall be monitored, read, and recorded on the driller's or mud log for a minimum of every 9 meters (30 feet) of hole drilled below the conductor casing, and

(d) A hydrogen sulfide indicator and alarm shall be installed in areas suspected or known to contain hydrogen sulfide gas which may reach levels considered to be dangerous to the health and safety of personnel in the area.

No exceptions to these = requirements will be allowed without the specific prior permission of the department.

\section{NEW SECTION}

WAC 332-17-140 WELL LOGGING. All wells shall be logged with an induction electric log or equivalent from total depth to the shoe of the conductor casing. The department may grant an exception to this requirement when well conditions make it impractical or impossible to meet the above requirements.

\section{NEW SECTION}

WAC 332-17-150 REMOVAL OF CASING. No person shall remove casing or any portion thereof from any well without first obtaining prior written approval from the department. In the request to remove casing, the applicant must describe the condition of the well, the proposed casing to be removed, all casing in the hole, location of plugs, and perforations.

\section{NEW SECTION}

WAC 332-17-160 DRILLING BOND. The owner or operator who proposes to dri11, redrill, or deepen a well for geothermal resources shall file with the department a good and sufficient bond in the sum of fifteen thousand dollars for each well or a fifty thousand dollar blanket bond for one or more wells being drilled, redrilled, or deepened at any time. The bond shall be filed with the department at the time of filing the 
application to drill, redrill, or deepening. The bond shall be made payable to the state of Washington, conditioned for performance of the duty to properly:

(1) Drill all geothermal wells,

(2) Operate and maintain producing wells, and

(3) Plug each dry or abandoned well in accordance with applicable rules and regulations of the department.

The bond shall be executed by such owner or operator as principal and by a surety company authorized to do business in the state of Washington as surety, conditioned upon the faithful compliance by the principal with the laws, rules, regulations, and orders under the Geothermal Resources Act and shall secure the state against all losses, charges, and expenses incurred by the state in obtaining such compliance by the principal of the bond.

A single core-hole bond shall be in the sum of five thousand dollars and a blanket core-hole bond shall be in the sum of twenty-five thousand dollars.

\section{NEW SECTION}

WAC 332-17-165 CANCELLATION OF BOND. Termination and/or cancellation of any bond will not be permitted until the well, or wells, for which the bond has been issued have been properly abandoned or another valid bond for such well or wells has been submitted therefore and approved by the department. A bond may be canceled upon transfer of the jurisdication of the well to and acceptance of jurisdiction by the department of ecology. No bond shall be released until the department in writing shall have authorized such release.

\section{NEW SECTION}

WAC 332-17-200 TRANSFER OF JURISDICTION TO DEPARTMENT OF ECOLOGY. Transfer of jurisdiction over a well to the department of ecology may be permitted provided it has been established that it is not technologically practical to produce electricity commercially or usable minerals cannot be derived from the well and provided, further, the department of ecology has by affidavit indicated its willingness to assume such responsibility. Transfer of such jurisdiction will relieve the owner or operator of further compliance with the provisions of the Geothermal Resources Act and these rules and regulations, however, the owner or operator shall be subject to applicable laws and regulations relating to wells drilled for appropriation and use of ground waters.

\section{NEW SECTION}

WAC 332-17-300 PROPOSER COMPLETION AND ABANDONMENT. Completion and abandonment of any weil or wells shall be conditioned upon implementation 
of adequate procedures to protect the environmental and esthetic qualities of the drill site, access roads, and other areas that were disturbed as a result of drilling or related operations

(1) Completion. For the purposes of the Geothermal Resources Act and these rules and regulations, a well will be considered as properly completed when drilling has been completed and a production head has been installed on the well pending actual utilization in the production of geothermal resources as defined in this act. Suspension of a well after completion and prior to actual production shall not exceed six months duration unless approved in writing by the department.

(2) Abandonment. A well shall be properly abandoned for the purposes of this act when:

(a) Drilling, redrilling, or deepening operations have ceased; or geothermal resources cannot be produced from the well; or the well no longer commercially produces geothermal resources; and proper cement plugs have been placed by the owner or operator and approved by the department; and

(b) The owner or operator has taken all appropriate steps to protect surface and ground waters and prevent the escape of deleterious substances to the surface.

(3) Site restoration. Cellars, pads, structures, and other facilities shall be removed. All drilling supplies and scrap shall be removed. The surface shall be graded and revegetated as appropriate to the immediate area or as otherwise specified by the department.

\section{NEW SECTION}

WAC 332-17-310 ABANDONMENT PROCEDURES. No well shal1 be plugged and abandoned untiT the manner and method of plugging have been approved or prescribed by the department. The owner or operator shall give notice to the department of the intention to abandon the well and the date and time abandonment procedures will commence.

(1) The notice shall specify the condition of the well and the proposed method of abandonment. The owner or operator shall furnish such additional information concerning the well condition and abandonment - procedures as may be required by the department.

(2) The owner or operator shall within twenty-four hours after giving notice of intent to abandon provide the department with a written notice setting forth the proposed abandonment procedures and the condition of the well.

(3) All wells to be abandoned shall have cement plugs placed in the well as prescribed herein. Such cement shall consist of a high temperature resistant admix unless waived by the department in accordance with the particular circumstances existing in the well.

(a) Cased holes.

(i) A cement plug shall be placed across all perforations in the casing, extending 30 meters ( 100 feet) below and 30 meters (100 feet) above the perforated interval.

(ii) A cement plug shall be placed across all casing stubs, laps, and liner tops, extending a minimum of 15 meters ( 50 feet) below and 15 meters (50 feet) above such stub, lap, or liner top. 
(iii) Casing shoes shall be straddled by a cement plug with a mintmum of 30 meters ( 100 feet) below and 30 meters ( 100 feet) above and below the shoe.

(iv) All annuiar space open to the surface shall be filled with cement to the surface.

(v) All casing exposed to the surface shall be cut off 6 feet below ground surface unless otherwise designated by the department.

(vi) A surface plug shall be placed in the casing extending for a minimum of 10 meters ( 30 feet) below the approved cut off top of the casing. The casing shall be capped by welding a steel plate on the casing stub.

(b) Open holes. Cement plugs shall be placed across fresh water zones, geothermal resource zones, to isolate formations, and to prevent interformational migration or contamination of fluids. Such plugs shall extend a minimum of 30 meters ( 100 feet) above and below all such zones.

(4) All intervals between plugs shall be filled with drilling mud.

(5) Within thirty days after plugging a well the owner or operator shall file an affidavit with the department setting forth in detail the method used in plugging the well and restoring the site. The affidavit shall be made on a form supplied by the department.

\section{NEW SECTION}

WAC 332-17-320 SUSPENSION. Drilling equipment shall not be removed from any well where drilling operations have been suspended before adequate measures have been taken to close the well and protect the surface and subsurface resources including fresh water aquifers. A suspended well shall be mudded and cemented as set forth in WAC 332-17310 of these rules and regulations or as otherwise approved by the department except that WAC 332-17-310(3) (a) (iv) - (vi) will not be required.

\section{NEW SECTION}

WAC 332-17-340 NOTICE OF CHANGE OF OWNERSHIP. Every person who acquires the right of ownership or right of operation of a geothermal well or wells shall within ten days notify the department in writing of the newly acquired owmership or right of operation and provide a bond equivalent to the bond supplied by the prior owner or operator. Each notice shall contain the following:

(1) Name, address, and signature of the person from whom the well or land was acquired;

(2) Name and location of such well or wells;

(3) Date of acquisition; and

(4) Description of the land upon which such well or wells is situated. 
NEW SECTION

WAC 332-17-400 RECORDS. The owner or operator of any well or wells shall keep or caused to be kept careful and accurate logs, core records, and history of the drilling of the well. The logs and tour reports shall be kept in the local office of the owner or operator and shall be subject during business hours to inspection by the department except during casing and abandonment operations when appropriate logs will be available at the well site.

Records that shall be filed with the department as set forth in RCW 79.76.210 are:

(1) The drilling $\log$ and core record showing the lithologic characteristics and depths of formations encountered, and the depths and temperatures of water-bearing and steam-bearing strata, and the temperature, chemical compositions, and other chemical and physical characteristics of fluids encountered. Core records shall show the depth, lithologic character, and the fluid content of cores obtained.

(2) The well history shall describe in detail in chronological order on a daily basis all significant operations carried out and equipment used during all phases of drilling, testing, completion, recompletion, and abandonment of the well.

(3) The well summary report shall accompany the drilling logs and well history report. It shall show the spud date, completion date, abandonment date, casing summary, fresh water zones, producing zones, total depth, well locations, tops of formations penetrated and bottom hole temperature.

(4) Production records shall be submitted monthly to the department on or before the 10th of each month for the preceding month on a form approved by the department.

(5) Electric logs, directional logs, physical or chemical logs, tests, water analysis, surveys including temperature surveys, and such other logs or surveys as may be run.

(6) A set of ditch samples if taken at not less than 30 meters (100 feet) intervals.

\section{NEW SECTION}

WAC 332-17-410 VERTICAL AND DIRECTIONAL WELLS. Deviation surveys shall be taken on a11 wells during the normal course of drilling at intervals not to exceed 152 meters ( 500 feet). The department may require a directional survey giving both inclination and azimuth or a dipmeter to be obtained on al1 wells. In calculating all surveys, a correction from true north to Lambert-Grid north shall be made after making the magnetic to true north correction. All surveys shall be filed with department as set forth in WAC 332-17-400. Wells are considered to be directional if inclination from vertical exceeds an average of five degrees. In directional wells directional surveys shall be obtained at intervals not to exceed 30 meters ( 100 feet) prior to, or upon setting any casing string or lines (except conductor casing) and total depth. 


\section{NEW SECTION}

WAC 332-17-420 DEPARTMENT TO WITNESS TESTS. Sufficient notice shall be given in adance to the department of the data and time when the owner or operator expects to run casing, test casing, conduct a drill stem test, or $\log$ a well in order that the department may have a representative on the drill site as a witness.

\section{NEW SECTION}

WAC 332-17-430 WELL DESIGNATION. The owner or operator shall place in a conspicuous location near the well site a sign setting forth the name of the owner or operator, lease name, wel1 number, permit number, and the quarter-quarter section or lot, township, and range of the well location. Such well designation shall (be) maintained until the well has been abandoned.

\section{NEW SECTION}

WAC 332-17-440 WELL SPACING. The department will approve proposed well spacing programs or prescribe such modifications to the programs as it determines necessary for proper development, giving considerationto such factors as:

(1) Topography of the area;

(2) Geologic conditions of the reservoir;

(3) Minimum number of wells required for adequate development; and

(4) Protection of environment.

\section{NEW SECTION}

WAC 332-17-450 RIGHT OF ENTRY. Department representatives shal1 have the right to enter upon any lands and examine such records related to the drilling, redrilling, deepening, or the completion, or the abandonment of, or production from any geothermal well to ensure compliance with the Geothermal Resources Act and these rules. Any owner or aperator who denies the right of entry of a department representative or willfully hinders or delays the enforcement of the provisions of the act and these rules or who otherwise violates, fails, neglects, or refuses to comply with any of the provisions of the act or these rules will be subject to the penalties as set forth in RCW 79.76.260. 


\section{NEW SECTION}

WAC 332-17-460 PITS OR SUMPS. The owner or operator shall provide pits and/or sumps of adequate capacity and design to retain all fluids and materials necessary to the drilling, production, and related operations on the well. No contents of pits and/or sumps shall be allowed to:

(1) Contaminate streams, artificial canals, waterways, ground waters, 1akes, or rivers;

and

(2) Adversely affect the environment, persons, plants, and wildlife;

(3) Adversely affect esthetic values of the property or adjacent properties.

When pits and/or sumps are no longer needed, they shall be pumped out and the contents disposed of in approved disposal sites unless otherwise approved by the department. 
The utilization of geothermal resources can be divided into two very broad categories: (1) utilization for the production of electricity, and (2) direct utilization in industry, space conditioning, and agriculture and aquaculture (Figure 7). These two broad categories can be further broken down on the basis of temperature and the relative percentage of steam and water.

Utilization of geothermal resources is no different than the use of steam or hot water produced by burning oil, coal, wood, or through nuclear reaction. The main differences lie in problems of corrosion or scaling which result from the chemical composition of some geothermal resources, making material selection critical; and the fact that geothermal resources must be used within relatively short transmission distance of the source.

\section{ELECTRICAL GENERATION}

The generation of electricity using geothermal resources began in Lardere110, Italy in 1904. Worldwide generating capacity has been slow to develop and it has been only since the early 1960's that significant gains in total generating capacity have been achieved.

\section{TABLE II}

Worldwide Geothermal

\section{Electrical Generating Capacity}

$\begin{array}{lcc} & \begin{array}{c}\text { Installed } \\ \text { Capacity }\end{array} & \begin{array}{c}\text { Future } \\ \text { Capacity MW* }\end{array} \\ \text { China, People's Republic. of } & 1 & \\ \text { El Salvador } & 60 & - \\ \text { Iceland } & 62 & 35 \\ \text { Italy } & 420.6 & -- \\ \text { Japan } & 165 & -- \\ \text { Mexico } & 150 & 55 \\ \text { New Zealand } & 202.6 & 30 \\ \text { Philippines } & 59.2 & -- \\ \text { Turkey } & 0.5 & 710 \\ \text { U.S.S.R. } & 5 & -- \\ \text { United States } & 663 & 1019 \\ & - & - \\ & 1,788.9 & 1849\end{array}$

*Planned to be on line by 1982 .

Courtesy of John W. Lund, Geo-Heat Utilization Center. 


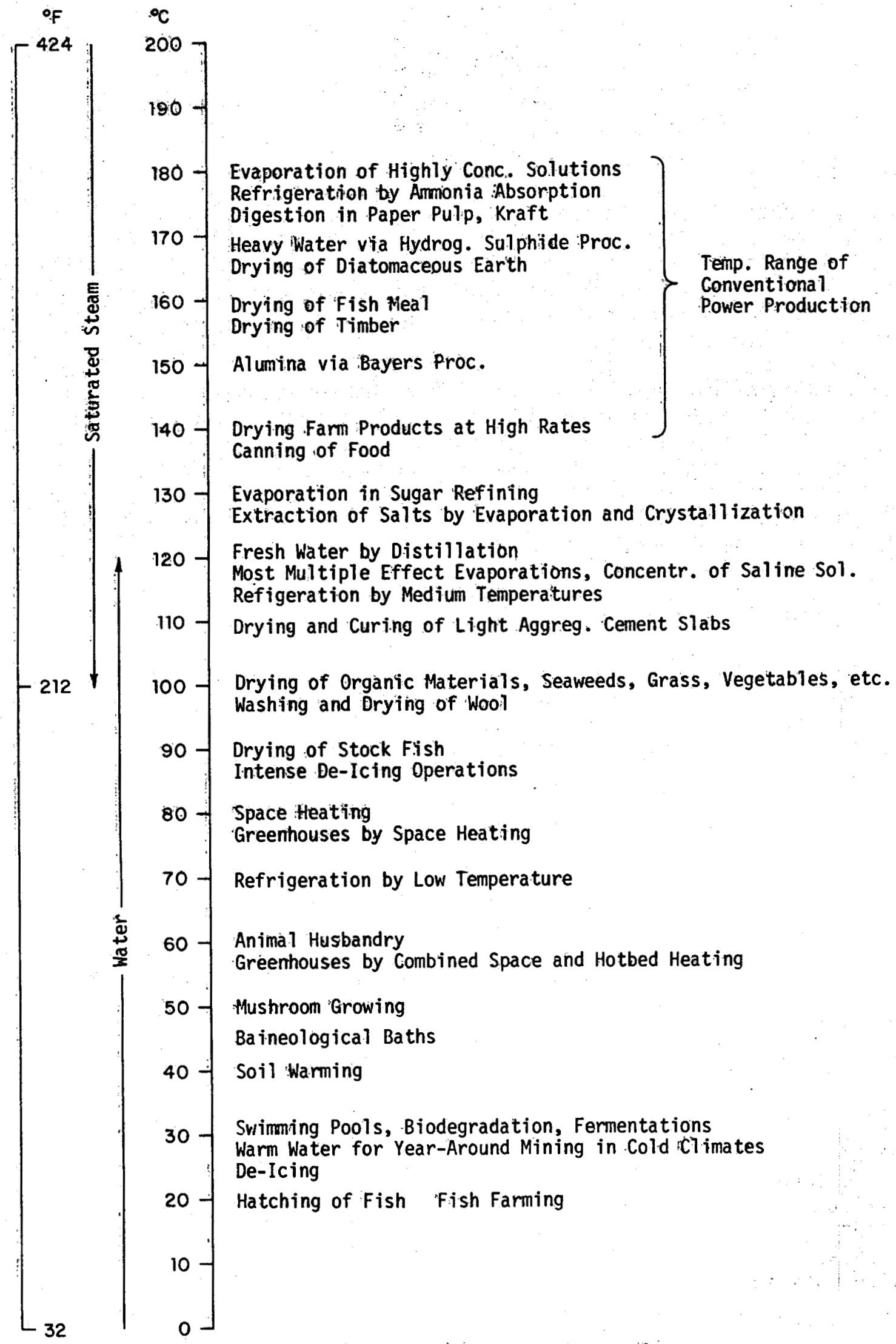

Direct theribal applicaition of geothermal energy.

(After Lindal, 1974) 
Electrical generation can be accomplished utilizing geothermal resources in a number of ways dependent upon the temperature and the relative percentage of steam and water. The four primary generating plant types include: (1) those utilizing dry steam, (2) flashed steam in either single or multiple flash units, (3) binary plants which utilize secondary working fluids where for some reason, the direct use of the geothermal resource is impossible or undesirable, and (4) plants utilizing a combination of flashed steam and binary technology. A fifth plant type is a hybrid where geothermal resources are used in conjunction with fossil fuels, solar energy, or biomass for electrical generation.

\section{A. Dry Steam Plants}

To date, the majority of the worldwide geothermal electrical generation capacity is from dry steam fields, such as those at Larderello, Italy and The Geysers in California.

In a dry steam plant (Figure 8 ) the steam is brought to the surface by a series of wells, and after separating out rock debris, the steam is piped directly through a collector into the steam turbines which in turn drive the generators. On exiting from the turbine, the steam is condensed in a cooling tower and injected back into the reservoir.

\section{Dry Steam Power Plant}

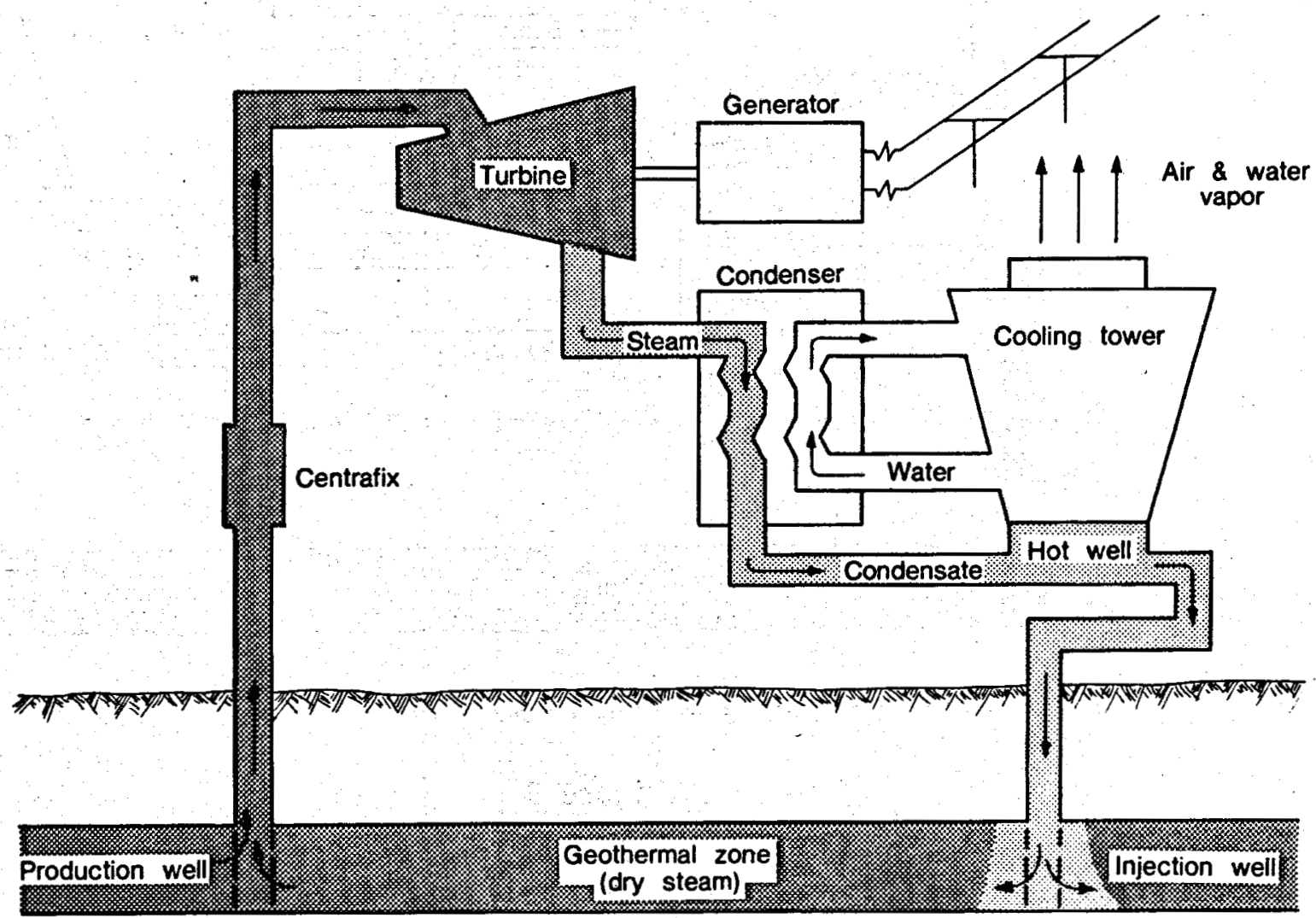




\section{B. Flashed Steam Plants}

Flashed steam plants as pictured in Figures 9 and 10 must rely upon that fraction of steam which will flash from the superheated water as the resource is brought to the surface and the pressure is reduced. Plant efficiency can be increased in many cases by flashing at decreasingly lower pressures in order to obtain as much steam as possible from a given volume of water. Once the steam is separated from the water, it is fed into the turbines as in the dry steam plant. The remaining water fraction and condensate are both reinjected.

\section{Flash Steam Power Plant}

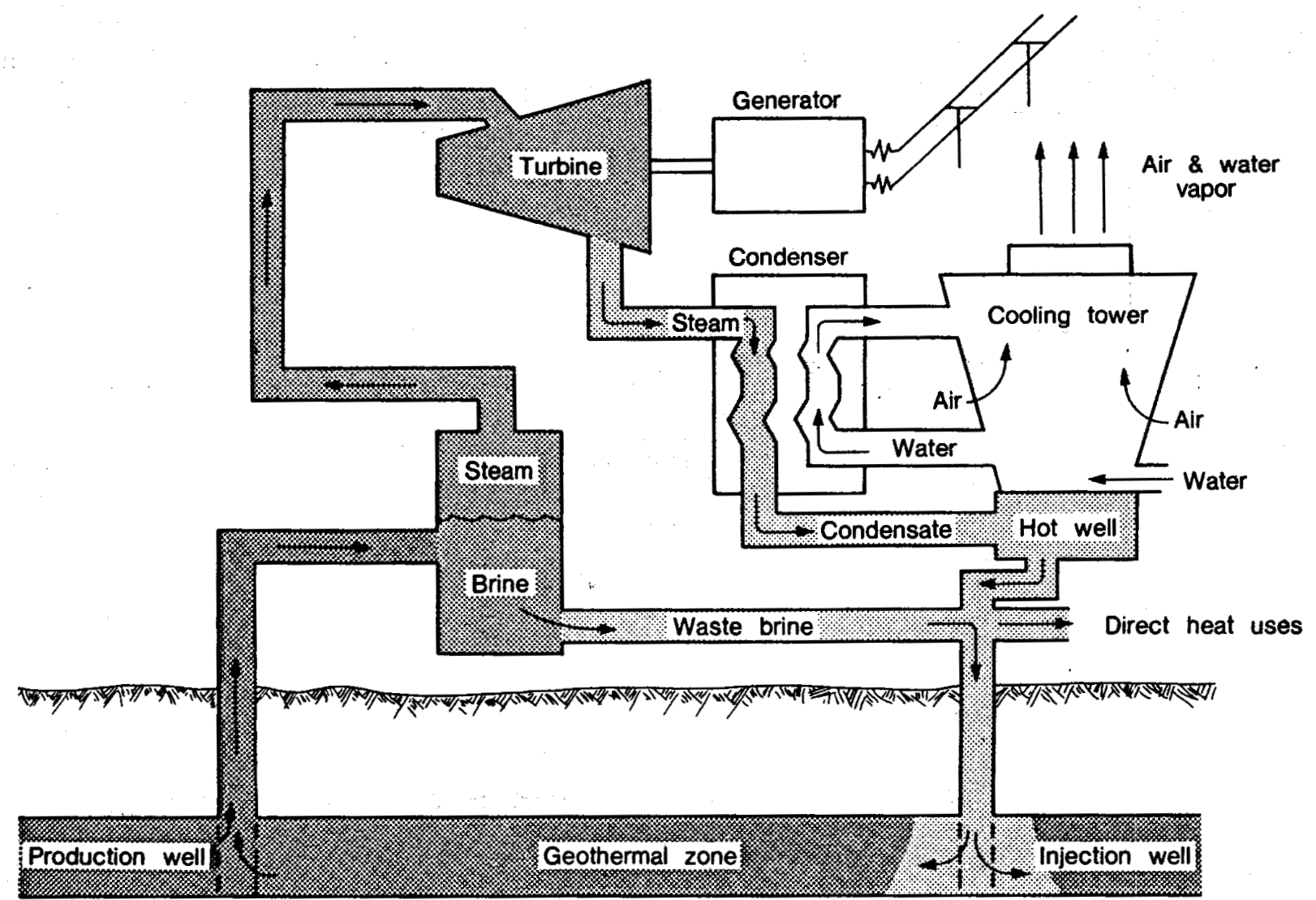

Courtesy of Earth Science Laboratory, University of Utah Research Institute

Figure 9 


\section{Double Flash Power Plant}

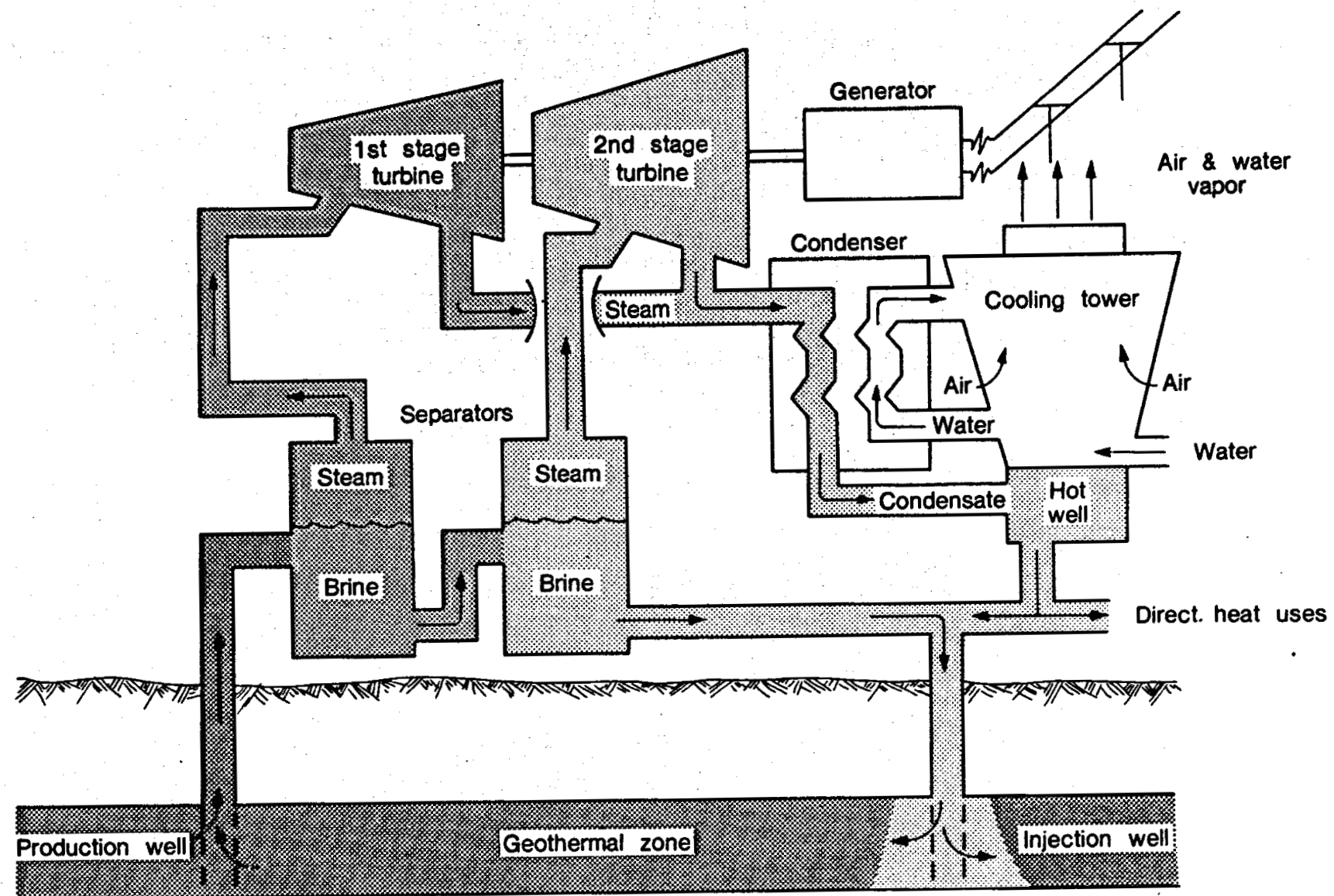

Courtesy of Earth Science Leboratory, University of Utah Research Institute

Figure 10

\section{Binary Plants}

Binary plants (Figure 11) use secondary working fluids such as freon, isobutane, or isopentane to drive turbines.

The use of a binary cycle plant allows for the generation of electricity utilizing geothermal fluids which are below the temperature where flashing will produce substantial amounts of steam or where because of corrosion or scaling problems associated with some geothermal resources, direct use is impractical.

In the binary cycle plants, such as that found at Raft River, Idaho, the geothermal fluid is pumped from the production well through a heat exchanger where the secondary fluid is vaporized, and then geothermal fluids are injected into the reservoir. The vaporized secondary working 
floid is then piped through the turbines, which drive generators, and fimally comdensed for reuse. By maintaining the reservoir pressure of the geothemal fluid, gas release is eliminated, thus reducing some scaling or corrosion problems as well as eliminating the potential for major air polution from gases often encountered in geothermal reservoirs. In addition, by using a heat exchange, scaling and corrosion can be limited to the primary mode of the heat exchanger making for greatly increased ease of replacement or repair.

Binary cycle plants can also be used in conjunction with flashed steam plants. In such an arrangement, the water that remains after flashing is passed through a binary cycle unit thus extracting additional energy and making for more efficient use of the resource.

\section{Binary Cycle Power Plant}

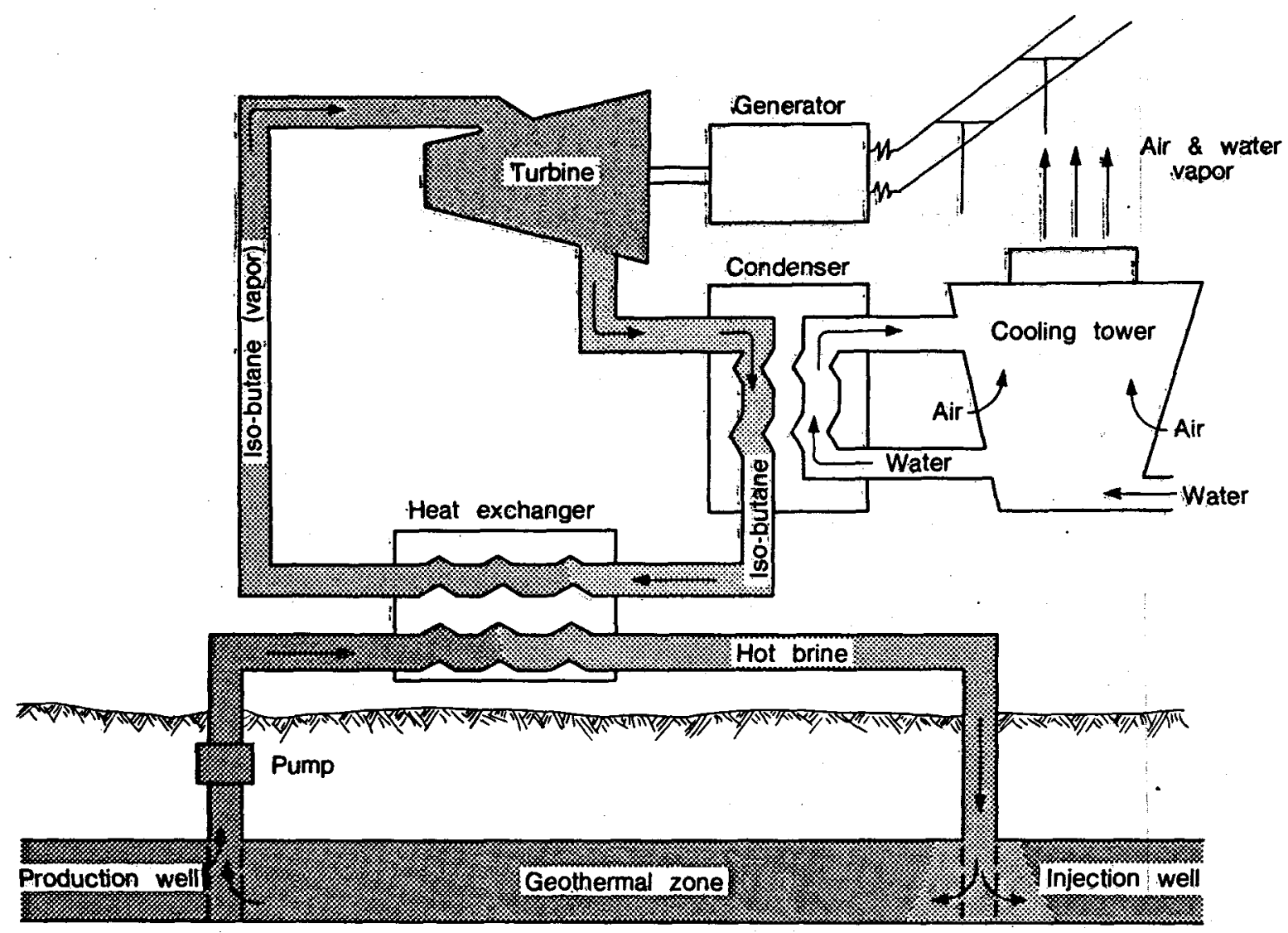

Courtesy of Earth Science Laboratory, University of Utah Research Institute

Figure 11 


\section{Hybrid Plants}

Hybrids make use of geothermal resources together with a secondary energy source such as coal, biomass, or solar energy. The hybrid plant can utilize geothermal resources which are below the temperature where flashing produces usable amounts of steam, and in some cases, below the temperature needed for economical use in binary cycle plants. In a hybrid plant, the geothermal resources are used as preheated water which is boosted through the use of a secondary energy source to produce steam. In some cases, such as with the use of biomass, the geothermal resource is also used for drying the organic material, thus increasing the burning efficiency.

\section{DIRECT UTILIZATION}

Direct use of geothermal resources can supply a large part of our energy needs for industrial processing, commercial and residential heating and cooling, agriculture, and aquaculture. Geothermal resources with temperatures ranging from $10^{\circ} \mathrm{C}\left(50^{\circ} \mathrm{F}\right)$ to $100^{\circ} \mathrm{C}\left(212^{\circ} \mathrm{F}\right)$ can successfully be utilized (Figure 12) although below $60^{\circ} \mathrm{C}\left(140^{\circ} \mathrm{F}\right)$ the temperature generally must be boosted through the use of conventional boilers or heat recovery systems to meet the needs of industrial processing and space conditioning. The direct use of geothermal resources has several advantages over the use of the resource for electrical production. These are:

1. Resources with direct use potential are believed to outnumber electrical prospects by as much as ten to one.

2. Drilling can generally be accomplished at much lower costs using conventional water well drilling equipment and technology.

3. Development time is usually much shorter than with electrical generation development.

4. The resource can be transported over considerable distance with temperature losses of as little as $0.1^{\circ} \mathrm{C}\left(0.2^{\circ} \mathrm{F}\right)$ per kilometer in comparison to steam transport which is limited to approximately 2 kilometers.

5. A conversion efficiency of from 70 to 90 percent is possible in comparison to a conversion efficiency of from 5 to 25 percent for electrical production.

Although the direct use of geothermal energy has been proven to be the most efficient use of the resource, the efficiency can be enhanced through cascading or multi-stage use of the resource. This is also true of resources which are or may be utilized for electrical generation. An optimized cascading of the resource could include electrical generation, industrial processing, space heating, and finally aquaculture or recreational use. Cascading will also improve the economic picture of any geothermal development and should be considered whenever possible. Details of economic evaluation are presented in Chapter $V$. 


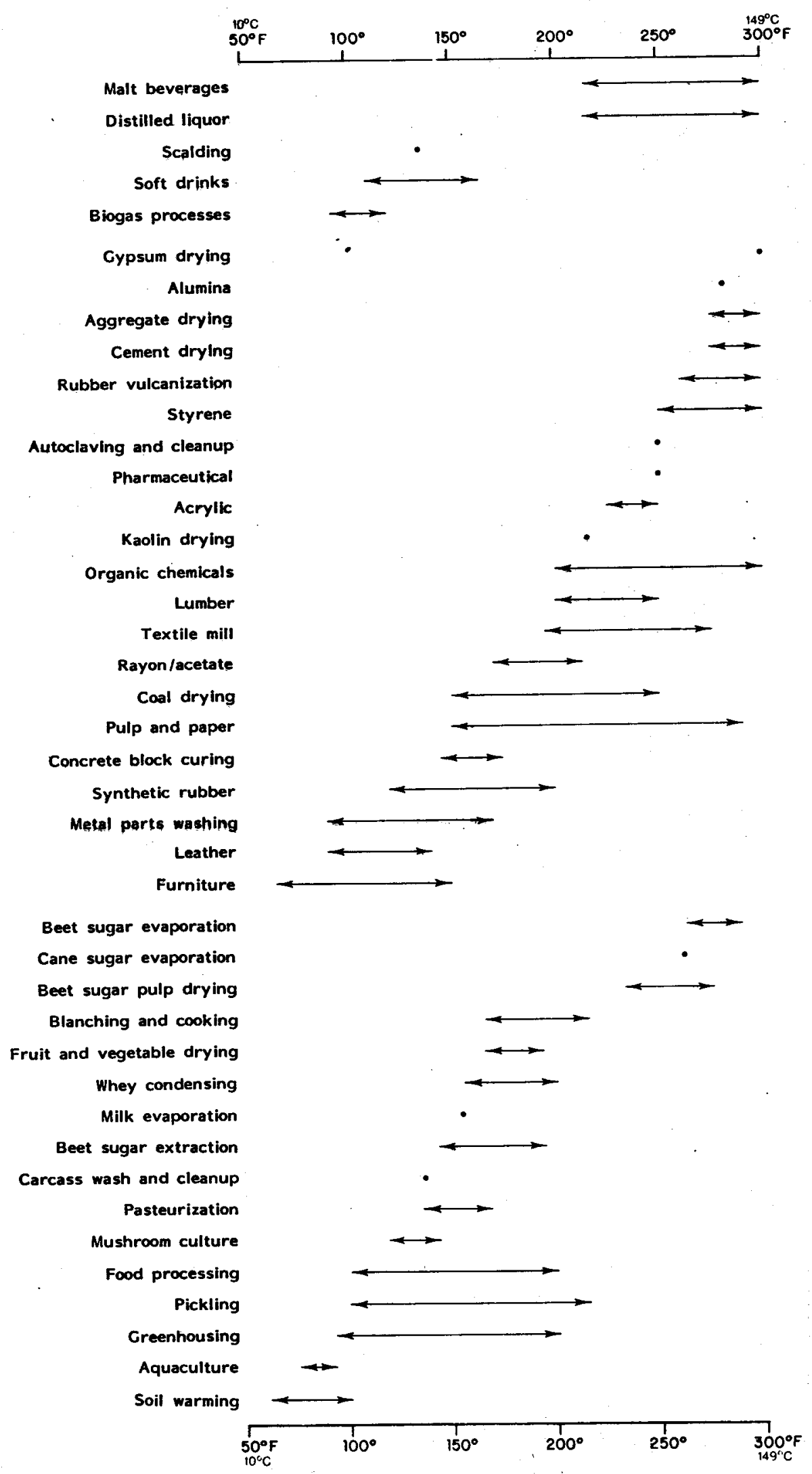

TEMPERATURES REQUIRLD FOR VARIOUS DIRECT GEOTHERMAL APPLICATIONS

Figure 12 
A. Industrial Processing

The energy needs of many industrial processes can be fully or partially met using geothermal energy (Figure 12).

The earliest industrial application involved the use by the Etruscans of boric acid deposited by hot water and steam at Larderello, Italy. By 1818, boric acid was being commercially extracted with several factories being built in the area for this purpose by the mid 1800's. In New Zealand, the Tasman Pulp and Paper Company uses approximately 18 tons of steam per hour for timber drying, black liquor evaporation, and pulp and paper drying (Wilson, 1974). In Iceland, a diatomacous slurry, dredged from Lake Myuata is dried in large rotary drum dryers using geothermal energy (Lindal, 1974). In Klamath Falls, Oregon, Medo-Bel Creamery pasteurizes milk using the heat from geothermal fluids (Be]castro, 1978). Geothermal Food Processing located at Brady Hot Springs, Nevada uses high temperature geothermal resources for the dehydration of onions and other vegetables. Several other facilities are presently being built or planned which will use geothermal resources for a number of industrial processes, most notably the production of alcohol.

\section{B. Space Conditioning}

The greatest near term potential for the direct utilization of geothermal resources lies in the field of space heating and cooling. Space. conditioning with geothermal water at temperatures below $100^{\circ} \mathrm{C}\left(212^{\circ} \mathrm{F}\right)$ could account for nearly 50 percent of the total resource utilization below $149^{\circ} \mathrm{C}\left(300^{\circ} \mathrm{F}\right)$. The usable temperature range for space conditioning is from $10^{\circ} \mathrm{C}\left(50^{\circ} \mathrm{F}\right)$ to $100^{\circ} \mathrm{C}\left(212^{\circ} \mathrm{F}\right)$ (Figure 13$)$. Space conditioning can take the form of either a single well supplying an individual user or group of users or through the formation of geothermal heating districts where geothermal fluids are made available to users much as natural gas is now available.

Space Heating and Cooling with Geothermal Fluids

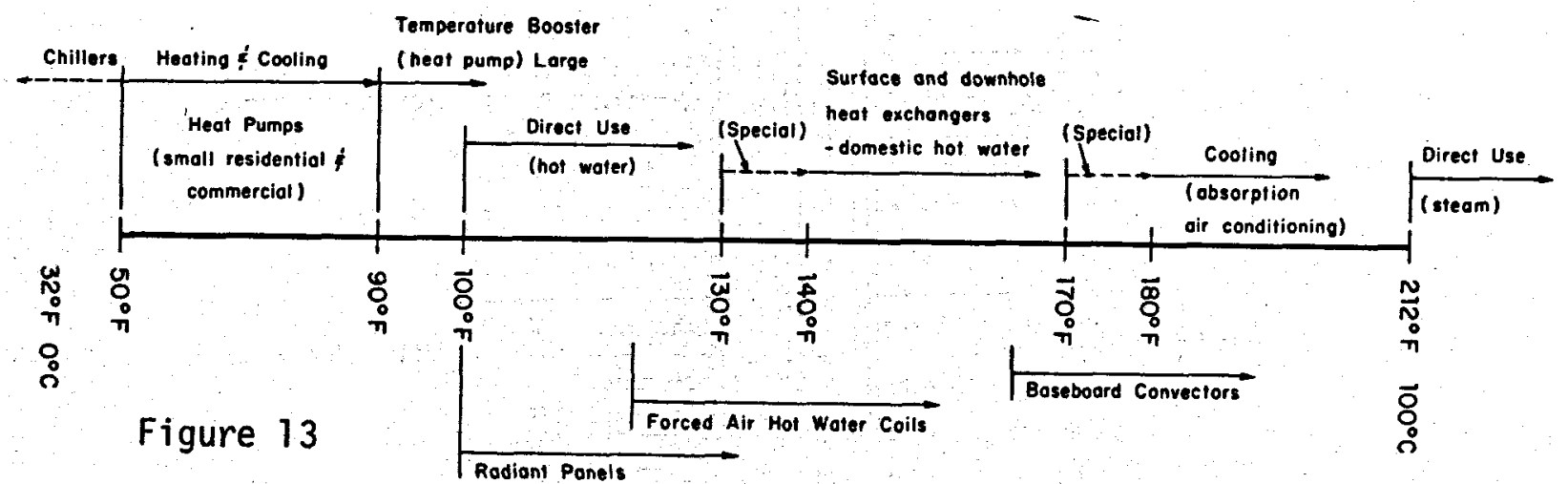

The district heating system in Reykjavik, Iceland is probably the best known example of the use of geothermal energy for space conditioning. The system supplies some 15,600 homes and apartments which houses 97 percent of the population of over 113,000 (Lienau 1980). In the Reykjavik system, geothermal fluids are transported to the city by large capacity pipes from a series of wells situated about 13 miles from the 


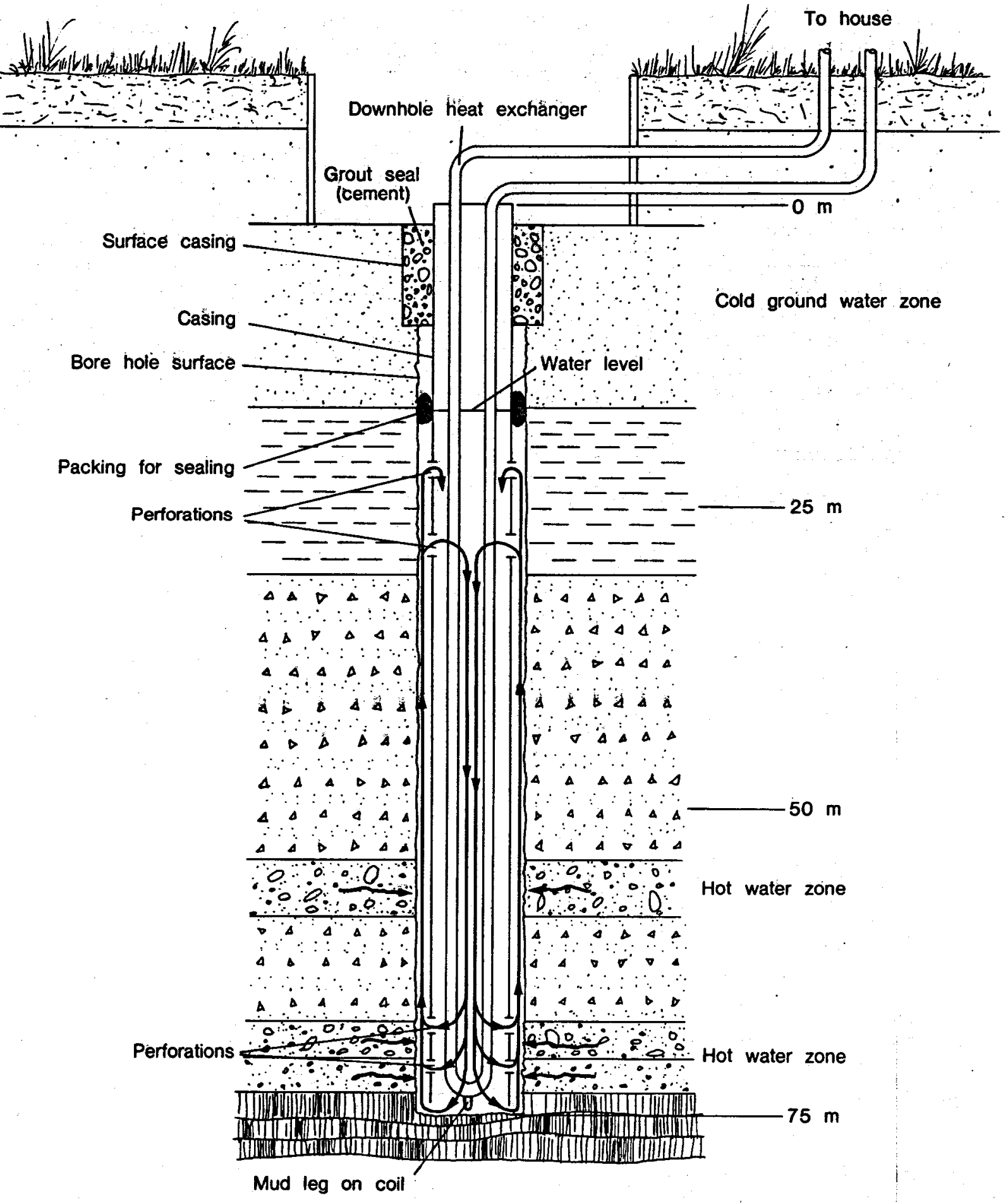

Typical downhole heat exchanger installation (not to scale) 
city. Large storage tanks located near the city are used in order to meet varying flow demands. The system which is designed to meet the base heating load of the city uses fossil-fuel fired boilers to boost the temperature of the geothermal water for periods of peak heating demand. The water which is transmitted from the storage tanks to individual users by a network of small diameter pipes, enters each residence through a valve sized to meet the heating demand of that unit and heating costs are based on the size of the valve. (Lund, 1977).

Presently, geothermal district heating systems are being constructed in $\mathrm{Klamath}$ Falls, Oregon and Boise, Idaho.

In $\mathrm{Klamath} F a l 1 \mathrm{~s}$, Oregon, there are presently over 500 homes heated geothermally utilizing a single well to heat a single residence. A typical residential heating system in Klamath Falls (Figure 14) consists of a 10 inch diameter well with an average depth of 300 feet which is cased to depth with eight inch diameter steel casing. The casing is perforated at the hot water $10^{\circ} \mathrm{C}$ to $96^{\circ} \mathrm{C}\left(140^{\circ} \mathrm{F}\right.$ to $\left.205^{\circ} \mathrm{F}\right)$ zones and just below the static water level to allow natural circulation of the geothermal water between the annulus and the casing. Two downhole heat exchangers are then placed in the well--a two inch diameter loop for the heating system and a three-quarter inch diameter loop for domestic hot water. City water is fed into the heating loop and circulated through a forced-air system, baseboard convectors, or radiant panels for space heating (Figure 15) (Lund, 1978). City water is also circulated through the three-quarter inch loop to supply all domestic hot water needs.

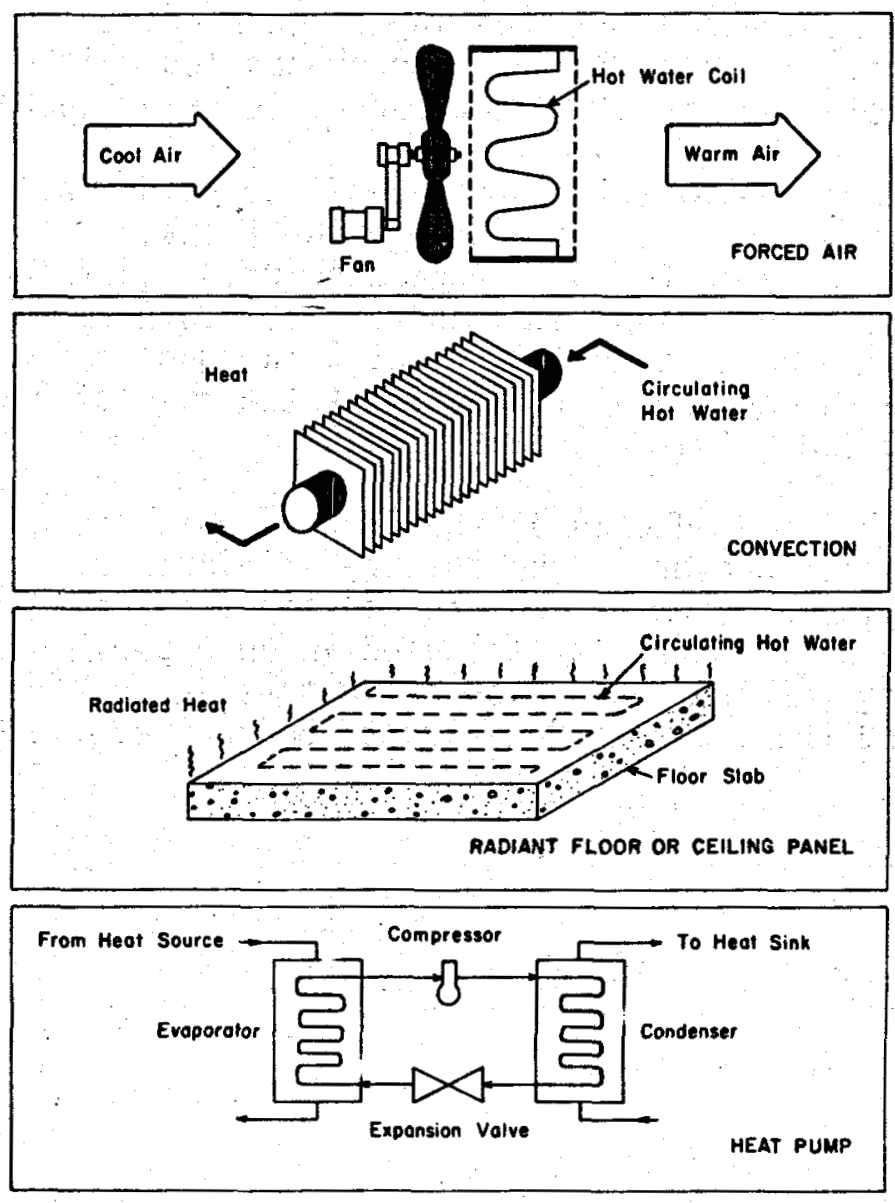

Figure 15 Typical Heat Convectors and Heat Pump 


\section{Agriculture and Aquaculture}

Agriculture and aquaculture-related uses generally require the lowest temperature geothermal resources. Typically temperatures between $27^{\circ} \mathrm{C}$ and $82^{\circ} \mathrm{C}\left(80^{\circ} \mathrm{F}\right.$ to $\left.180^{\circ} \mathrm{F}\right)$ will meet the requirements of agriculture and aquaculture production and processing (Figure 16).

Today, of the 7,000 megawatts thermal (MWt) which are provided by geothermal resources, approximately 5,500 MWt are used in agriculture, aquaculture, and animal husbandry (Lienau, 1980). The Soviet Union is the leader in the use of geothermal resources for agriculturally related activities with Hungary in second place. Unfortunately, very little has been published concerning the utilization of geothermal resources in the Soviet Union.

In Hungary over 13 million square feet of greenhouses are heated geothermally. Many of the greenhouses are built on rollers so that they can be easily moved, for ground cultivation and preparation using large equipment, and then returned to position.

In Japan, geothermally heated greenhouses used for the growing of flowers and vegetables cover over 157,000 square feet. Many of the greenhouses are operated as tropical gardens for sightseeing purposes. In addition, the Japanese are utilizing geothermal energy in poultry raising and the breeding and raising of carp and eels. A more exotic use is the rajsing of alligators and crocodiles, although the reptiles are bred purely for sightseeing purposes (Lienau, 1980).

The Geo-Products Corporation greenhouse operation, near Susanville, California, is the largest in the United States. At present 30 greenhouses are being used for the hydroponic raising of tomatoes and cucumbers. The operation which is totally geothermally heated, is expected to expand to over 200 units. Near Buhl, Idaho, Fish Breeders of Idaho are raising channel catfish at the rate of 500,000 pounds per year in $32^{\circ} \mathrm{C}\left(90^{\circ} \mathrm{F}\right)$ water (Lienau, 1980).

Research is being conducted at the Oregon Institute of Technology GeoHeat Utilization Center on the culture of giant prawns (Macrobrachium rosenbergi) in waste water from the institute's geothermal heating system. The waste water is also used in an experimental greenhouse, thus allowing for the evaluation of multi-stage use of geothermal resources and the economic benefits to be derived from cascading. 


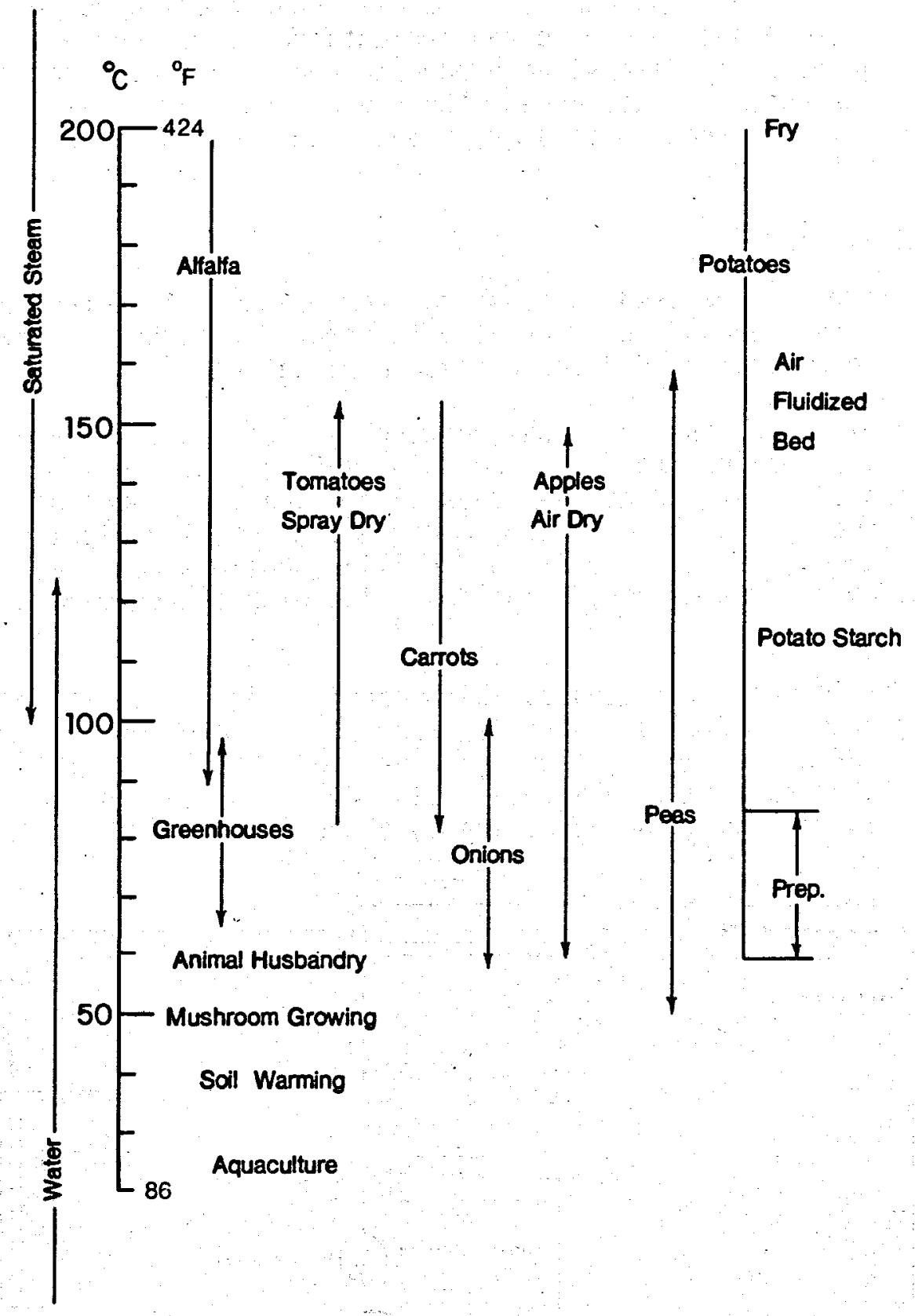

Agricultural uses for geothermal resources.

Figure 16 


\section{INDIRECT UTILIZATION}

In many situations the direct use of geothermal resources may prove to be impossible or uneconomical. The temperature of the geothermal fluid available may be lower than that required for a desired application and/or the flow rate may be insufficient to meet the heating demand. In other instances it may be uneconomical to meet peak heating demands with a totally geothermal system due. to requirements for large numbers of wells and large pipeline dimensions needed to meet those peak demands. Under any of the above circumstances, the use of auxillary boilers or heat recovery systems (heat pumps) may prove technologically and economically attractive.

\section{A. Auxiliary Boilers}

Auxiliary boilers can be used to boost the temperature of geothermal fluids to meet peak demands or where the temperature of the geothermal resources is below that needed for a given application.

In Reykjavik, Iceland, the municipal heating system uses auxiliary fossil fuel fired boilers to boost the $80^{\circ} \mathrm{C}\left(176^{\circ} \mathrm{F}\right)$ water to $110^{\circ} \mathrm{C}$ $\left(230^{\circ} \mathrm{F}\right)$ during the 15 to 20 coldest days of the year. Because of this capability, fewer wells and more economically demonstrated pipelines can be employed (Zoega, 1974). The use of auxiliary boilers can thus also serve as a back up system should problems arise with the primary geothermal system.

In the case of industrial processes which require high temperature water, the geotherimial fluids can serve as preheated water which cath be bodsted to required temperatures using conventional boilers. This has been demonstrated to result in a substantial reduction in the use of fossil fuels as well as being economically sound.

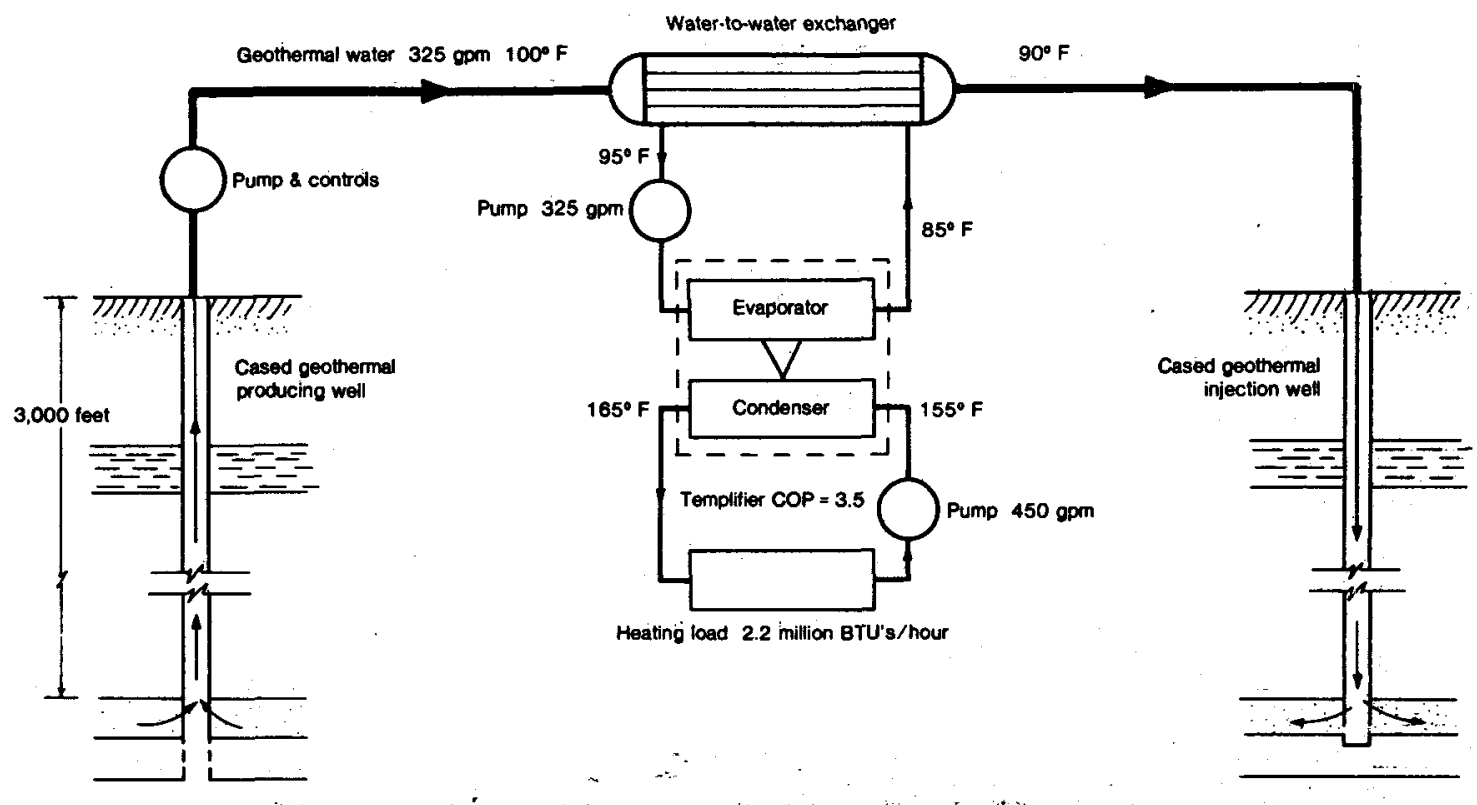

Schernatic diagram of use' as low-grade geothermal energy temperature - ấmpilfièd for $165^{\circ} \mathrm{F}$ heating load

Heat Recovery System 


\section{B. Heat Recovery Systems - Heat Pumps}

One of the most exciting developments in the use of low temperature geothermal resources is the development of water-to-water and water-toair heat pumps. The heat pump as pictured in Figure 17 can be utilized with water temperatures as $10 \mathrm{w}$ as $10^{\circ} \mathrm{C}\left(55^{\circ} \mathrm{F}\right)$. At the present time, the units are commercially available with output temperatures up to $110^{\circ} \mathrm{C}$ $\left(230^{\circ} \mathrm{F}\right)$. The heat recovery system extracts heat from the geothermal fluid, boosts the temperature, and finally transfers that heat to either a secondary fluid such as water or air. In the reverse mode, the waterto-air heat pump will provide air conditioning by extracting heat from the air and transferring that heat to water, which is then pumped into the ground. The principal advantage of the water heat pump in comparison to an air heat pump is the uniform temperature of the heat source or sink, thus allowing for much greater efficiency.

The energy savings which is known as the coefficient of performance (COP) is calculated by dividing the Btu output of the system by the Btu input to the system. The energy savings (COP) will rise with the temperature of the geothermal resource.

Several geothermal heat pump installations are presently in use. The largest use is in Criel, France where 4,000 dwellings are heated using low'temperature geothermal fluids. The heat pumps are used to extract heat from the water returning from the first stage of the heating system. In this way the total amount of heat obtained from the geothermal resource is approximately double that which could otherwise be extracted (J.D. Garnish, 1978).

In Salt Lake City, Utah the 28 story office building of the Church of Jesus Christ Latter-day Saints is totally space conditioned using a water-to-air heat recovery system.

The firm of Burmeister and Wain located in Copenhagen, Denmark has recently developed the technology needed to produce heat pumps for use in municipal district heating systems. This development may allow for the construction of geothermal district heating systems in many areas where high temperature geothermal resources exist only at commercially unacceptable depths.

For a more detailed account of the direct and indirect use of geothermal resources for industrial processing, space conditioning, and agriculture and aquaculture, the reader is referred to the Geothermal Resource Council's Special Report No. 7, Direct Utilization of Geothermal Energy: A Technical Handbook. 


\section{SELECTED REFERENCES}

Anderson, D.N. and Lund, J.W., eds., 1980, Direct Utilization of Geothermal Energy-A Technical Handbook: Geothermal Resources Council Special Report No. 7, Davis, California.

Belcastro, E., 1978, Geothermally pasteurized milk process: proceedings Direct Utilization of Energy - A Symposium, Geothermal Resources Council, Davis, California, p. 103-104.

Garnish, J.D., 1978, Progress in geothermal energy: Endeavour, New Series v. 2, no. 2, p. 66-7l.

Koenig, J.B., 1973, Worldwide status of geothermal resources development: Geothermal Energy, edited by Kruger and Otte, Stanford University Press, Stanford, California, p. 15-58.

Kruger, P. and Otte, C., eds., 1973, Geothermal Energy - Resources, Production, Stimulation: Stanford University Press, Stanford, California, $360 \mathrm{p}$.

Lienau, P.J., ed., 1978, Agribusiness Geothermal Energy Utilization Potential of Klamath and western Snake River Basins, Oregon: GeoHeat Utilization Center, Oregon Institute of Technology, Klamath Falls, Oregon, $180 \mathrm{p}$.

Lienau, P.J., 1980, Geothermal Resource Utilization: presentation to AAAS Annual Meeting, $4 \mathrm{p}$.

Lienau, P.J. and Lund, J.W., eds., 1974, Multipurpose Use of Geothermal Energy: proceedings of the International Conference on Geothermal Energy for Industrial, Agricultural, and Commercial - Residential Uses, Oregon Institute of Technology, Klamath Falls, Oregon, 239 p.

Lindal, B., 1974, Geothermal energy for process use - Multipurpose Use of Geothermal Energy: proceedings of the International Conference on Geothermal Energy for Industrial, Agricultural and Commercial Residential Uses, Oregon Institute of Technology, Klamath Falls, Oregon.

Lund, J.W., 1977, Geothermal energy in Iceland: USDI - Geological Survey Report, Oregon Institute of Technology, Klamath Falls, Oregon.

Lund, J.W., 1978, Geothermal energy utilization for the homeowner: Oregon Institute of Technology, Klamath Falls, Oregon (prepared for the Oregon Department of Energy), 29 p.

Petersen, B., 1980, Large Diesel Driven Heat Pumps for District Heating: Burmeister and Wain, Copenhagen, Denmark.

Petroleum Information Corporation, 1979, The Geothermal Resource: Denver, Colorado. 
Reistad, G.M.; Schmisseur, W.E.; Shay, J.R. and Fitch, J.B., 1978, An evaluation of uses for low to intermediate temperature geothermal fluids in the Klamath Basin, Oregon: Bulletin No. 55, Oregon State University, Engineering Experiment Station.

Ryback, L., 1979, Urban heating from geothermal aquifers in the Paris Basin: proceedings, A Symposium on Geothermal Energy and its Direct Uses in the Eastern United States, Geothermal Resources Council Special Report, No. 5, Davis, California.

Wahl, E.F., 1977, Geothermal Energy Utilization: A Wiley-Interscience Publication, John Wiley and Sons, New York, 302 p.

Wilson, R.D., 1974, Use of geothermal energy at Tasman Pulp and Paper Company Limited - New Zealand - Multipurpose Use of Geothermal Energy: proceedings of the International Conference on Geothermal Energy for Industrial, Agricultural, and Commercial - Residential Uses, Oregon Institute of Technology, Klamath Falls, Oregon.

Zoega, J., 1974, The Reykjavik municipal district heating system Multipurpose Use of Geothermal Energy: proceedings of the International Conference on Geothermal Energy for Industrial, Agricultural, and Commercial - Residential Uses, Oregon Institute of Technology, Klamath Falls, Oregon. 


\section{CHAPTER $V$}

\section{ECONOMIC FACTORS OF OIRECT USE PROJECTS}

Once a geothermal resource has been geologically proven and the technical feasibility of a project confirmed, an economic analysis is undertaken. Economic analysis is a series of calculations which determine the annual cash flows of alternative energy scenarios in order to select the one which is most attractive in terms of return on investment and cost per unit of energy produced. U1timately, the decision to invest capital in a geothermal project hinges on the project's ability to accrue annual savings over the current fuel system, taking into account the project life, maintenance costs, cost of capital, fuel price projections and other factors.

Geothermal energy requires a relatively large capital investment at the beginning of a project, with small annual operating costs thereafter. The initial capital costs for a small district heating system, attributable to production wells, pipelines, heat exchangers, possible injection wells, and various other items, may run as high as several million dollars. By contrast, the initial investment to provide natural gas heat to the same district would include only the cost of a central boiler and distribution lines. After that, the operating and maintenance costs for the two systems may be comparable, while the natural gas users must continually pay for their fuel, the geothermal users have no fuel costs at a11. Thus, two systems with fundamentally different cost structures must be compared. The economic analys is must show whether or not the smaller annual cost and larger initial capital investment for the geothermal project is cheaper overall than the conventional fuel system.

A major problem with economic analyses of alternative energy systems stems from the fact that energy price forecasting is often speculative and unreliable. Furthermore, different forms of energy escalate at different rates. Forecasts of conventional fuel costs are available through numerous government agencies, trade associations and even private firms. The annual inflation rates used at the Geo-Heat Utilization Center at the Oregon Institute of Technology (OIT) over the past three years are 12.2 percent for nautral gas, 9.5 percent for electricity, and 8.5 percent for 0 il. Naturally, assumptions of high rates of escalation of conventional fuel prices improve the relative economic feasibility of geothermal projects. Thus, OIT's inflation rates, have proven to be grossly understated, which means that all the geothermal. projects evaluated over this three year period have a higher degree of feasibility than anticipated. Economic analyses consist of the following steps:

1. A. In the case of a system that is currently operating on conventional fuels, collect historical annual energy costs for that portion of the energy load that is to be converted to geotherma1.

B. In the case of a new development where historical fuel consumption data is not available, estimate the capital investment and installation costs of the conventional fuel system, the energy load, and current cost of conventional fuel. 
2. Obtain conservative escalation rates for conventional fuels over the life of the project.

3. Estimate the capital investment and installation costs of the geothermal system.

4. Estimate the annual operation and maintenance costs for both the conventional and the geothermal systems, projected with appropriate escalation rates over the life of the project.

5. Consider the effects of investment tax credits, depreciation, write-offs, and depletion allowances for both systems.

Table III is a guide to the cost data that should be considered in a feasibility study.

In effect, two alternatives are being evaluated. Alternative one is the system which used conventional fuel, calculating a series of annual cash flows over the estimated life of the project. Alternative two is the geothermal system with annual cash flows calculated over the life of the project. The annual cost of the geothermal system is subtracted from the annual costs of the conventional system, and the resulting net cash flows will indicate the annual savings or expenses resulting from the geothermal system as opposed to a conventional system.

In attempting to justify the capital investment of a geothermal system, the time value of money must be considered. The concept of the time value of money simply states that savings or revenues received at some future date are of less value than savings or revenues received today. For example, a series of annual savings of $\$ 10,000$ per year projected over the next 20 years would have a present value of $\$ 851,000$ if the cost of capital were 10 percent annually. For a 20-year project, the projected annual cost of each system would be forecast for each year and the net cash flow, which is the difference between the two systems, would be discounted back to the present worth using either the cost of capital or the minimum attractive rate of return. If the calculated present worth in favor of the geothermal project was equal to or greater than the additional capital investment required for the geothermal project, the project is economically feasible. If the calculated present worth of the savings resulting from the geothermal project is less than the additional investment required for the geothermal system, then the project is not economically feasible.

Figure 18 compares the annual costs of a conventional system versus a geothermal system. Notice that the total cost of the conventional system is less than the total cost for the geothermal system in the early years of the project. As the annual operating expenses of the conventional system increase more rapidly than the geothermal system, the two systems reach a point where annual operating costs are equal and from that time forward the geothermal system has lower total annual costs.

Another frequently used approach to cost analysis is to determine the "payback period". Payback simply sums the annual cash flows from the project to determine when the initial capital investment will be recovered (paid back). Virtually. all direct use geothermal projects 
require a large capital investment and operate at a loss during the early years of the project 1 ife. Nonetheless, with economic lives in excess of 20 years, most can pay back the initial capital investment many times over during the life of the project.

One problem with this type of analysis is that it does not take into account the time value of money. Many investors have limited funds and may try to invest over as short a time period as possible. Other investors are anticipating opportunities in the near future and want to retrieve their investment by some deadline. Often times small businesses lacking sufficient working capital are reluctant to invest these limited funds for long time periods.

Payback analysis also ignores total project life. For example: Project A requires a $\$ 100,000$ investment and will pay $\$ 25,000$ per year for five years. The interest rate of this project is approximately 8 percent. The payback is four years $(4 \times \$ 25,000)$. Project $B$ requires a $\$ 100,000$ investment and pays $\$ 15,000$ per year for 20 years. Based on the payback criteria, the investor would select project $A$, while project $B$ is far superior.

Table IV presents the 20-year cash flows for a district heating system developed by a municipality. The city wants to develop a geothermal heating system to provide heat for two schools, city hall, city shops, fire station, and the post office. These buildings were being heated by . electricity, heating $0 i 1$, and propane. The cost of the system was estimated to be $\$ 837,700$. The city hopes to finance this project with 8 percent tax-free municipal bonds paying interest annually and maturing in 20 years, and the city will be able to reduce their heating costs drastically over this time period. The project pays for itself in the 20 year period and has an excess present value at 8 percent of $\$ 239,539$.

Table $V$ presents the same data for an identical system, but assumes that a geothermal developer drilled the wells and installed the system selling the energy to the city at the same price as the city was currently paying for conventional fuel. The gross sales column is a composite of all conventional fuels used, inflated at their projected inflation rates over a 20-year period. Columns 2 and 3 apply depletion allowances and 10 year straight-line depreciation assuming the developer has numerous ongoing projects and can take advantage of these tax write-offs. Column 4 combines the electrical pumping costs and the system maintenance costs. Federal taxes are based on the assumption that the corporation is in a 48 percent effective tax bracket and can write-off losses against other income.

The second portion of Table $V$ presents an after tax cash flow of the project which includes an investment tax credit taken in the first year of $\$ 209,425$. When evaluated at 7 percent, the cash flows indicate that $\$ 1,179,442$ could be spent today on this project. The discounted cash flow at 12.22 percent indicates that the corporation would earn this rate after taxes. It is doubtful that the city would agree to pay conventional fuel rates for the next 20 years. It should also be emphasized on this particular project that retrofit costs were not considered for the individual buildings. 
TABLE III

BASICS OF ECONOMIC ANALYSIS

When performing economic feasibility studies for geothermal applications, the following data are required:

I. Capital Investment of the Geothermal System

A. Wells and Well-head Equipment

1. Production wells

2. Production well pumps

3. Well-head buildings

4. Power hook-up and controls

B. Piping Network

1. Primary supply pipeline

a. Excavation, bedding and backfill

b. Concrete tunnels where applicable

c. Pipeline

d. Fittings

e. Insulation

f. Installation

g. Special costs such as highway crossings, railroad crossings, riverbed crossings, etc.

2. Secondary distribution systems
a. Excavation, bedding and backfill
b. Concrete tunnels where applicable
c. Pipeline
d. Fittings
e. Insulation
f. Installation

C. Heat Exchanger System

1. Heat exchanger

2. Circulation pumps

3. Heat exchanger building

4. Control system and power hook-ups

5. Other equipment
a. Expansion surge tanks
b. Flashers
c. Reservoirs, etc.

D. Retrofit costs

1. Piping

2. Heat exchangers

a. Fan coil units

b. Convectors 
TABLE III cont.

3. Controls and hook-up

4. Other special equipment required

E. Overhead costs

1. Engineering

2. Contingencies

3. Other

II. Annual Costs of the Geothermal System

A. Operating costs

1. Power requirements (kilowatt hours plus cost per kwh)

a. Pumping

b. Circulation

c. Controls

d. Operating personnel salaries

2. Operator's salaries

3. Other

a. Billing

B. Maintenance costs

1. Periodic maintenance
a. Wells
b. Pipelines
c. Heat exchangers
d. Pumps

2. Maintenance personnel salaries

3. Shops

III. Costs of Conventional System

A. Capital investment (for existing conventional systems this cost would be zero)

B. Annual operating costs

1. Units required in $\mathrm{kwh}$, gallons of $0 i 1$, tons of coal, or cubic feet of natural gas, etc., and cost per unit

2. Salaries

3. Other

C. Annual maintenance cost

1. Periodic maintenance

2. Salaries

3. Shops 


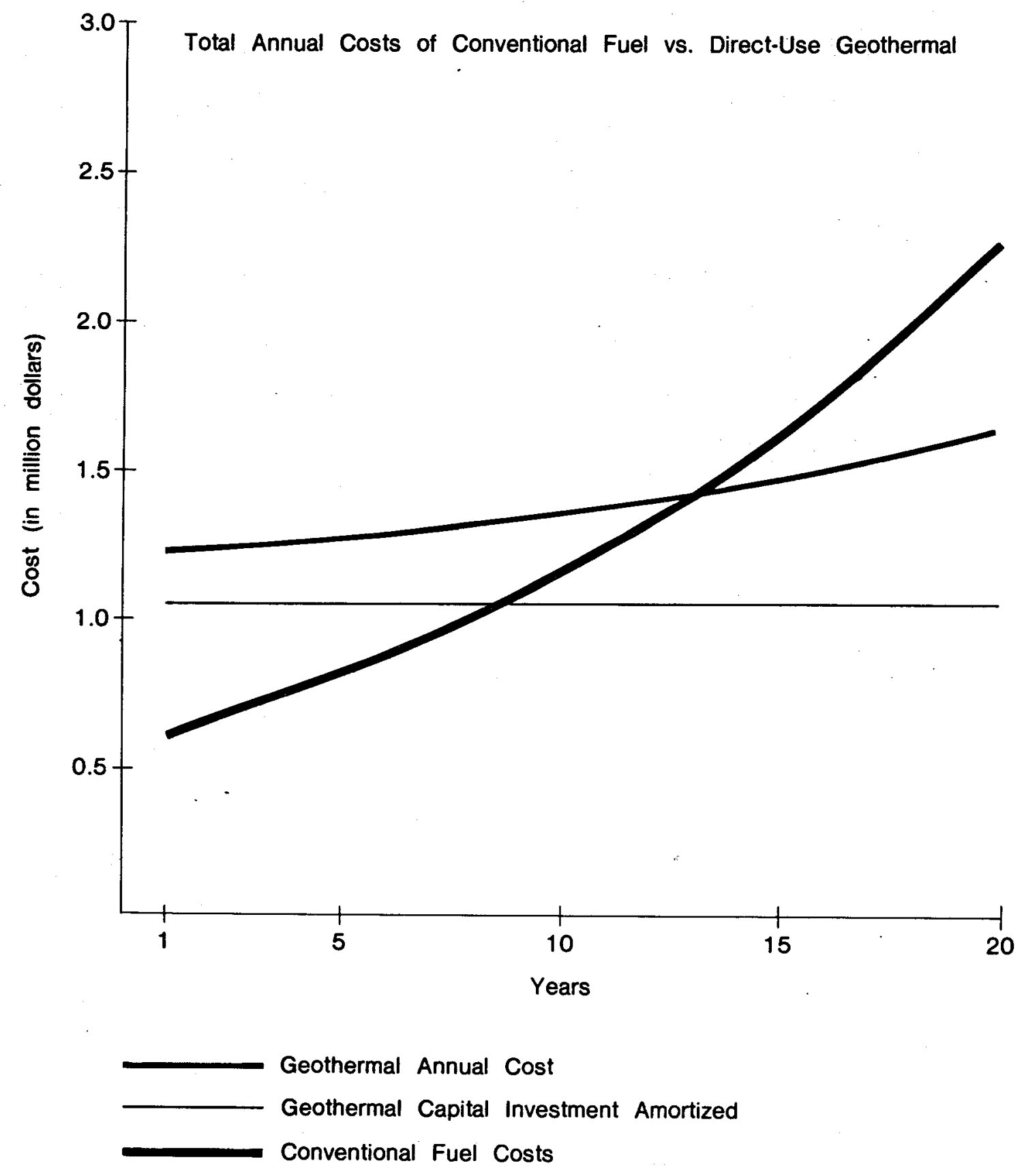

Figure 18 
CITY DEVELOPMENT

\begin{tabular}{|c|c|c|c|c|c|c|}
\hline $\begin{array}{c}\text { TOTAL } \\
\text { PRESENT } \\
\text { ELECTRICAL } \\
\text { COST } \\
\end{array}$ & $\begin{array}{r}\text { TOTAL } \\
\text { PRESENT } \\
\text { OIL COST } \\
\end{array}$ & $\begin{array}{c}\text { GEOTHERMAL } \\
\text { PUMPING } \\
\text { COSTS } \\
\end{array}$ & $\begin{array}{l}\text { GEOTHERMAL } \\
\text { OPERATION \& } \\
\text { MAINTENANCE } \\
\text { COSTS } \\
\end{array}$ & $\begin{array}{c}\text { BOND } \\
\text { INTEREST } \\
\text { AT } 8 \% \\
\end{array}$ & $\begin{array}{l}\text { ANNUAL } \\
\text { CASH } \\
\text { FLOW } \\
\end{array}$ & $\begin{array}{l}\text { PRESENT } \\
\text { VALUE } \\
\text { AT } 8 \% \\
\end{array}$ \\
\hline $\begin{array}{l}\text { COST } \\
32244 .\end{array}$ & $\begin{array}{l}\operatorname{COST} \\
28530 .\end{array}$ & $\begin{array}{l}\operatorname{cosT} \\
2436 .\end{array}$ & $\begin{array}{l}\text { COST } \\
10000 .\end{array}$ & $\begin{array}{l}\text { COST } \\
67016 .\end{array}$ & $S / Y R$ & $\begin{array}{l}\text { P.W. } \\
8 .\end{array}$ \\
\hline $\begin{array}{l}35308 . \\
38662 . \\
42335 . \\
46357 . \\
50760 . \\
55583 . \\
60352 . \\
65530 . \\
71152 . \\
77257 . \\
83886 . \\
91083 . \\
98898 . \\
107384 . \\
116597 . \\
126601 . \\
137464 . \\
149258 . \\
162064 . \\
175969 .\end{array}$ & $\begin{array}{c}30955 . \\
33586 . \\
36441 . \\
39539 . \\
42899 . \\
46546 . \\
50502 . \\
54795 . \\
59452 . \\
64506 . \\
69989 . \\
75938 . \\
82393 . \\
89396 . \\
96995 . \\
105239 . \\
114185 . \\
123890 . \\
134421 . \\
145847 .\end{array}$ & $\begin{array}{l}2667 . \\
2921 . \\
3198 . \\
3502 . \\
3835 . \\
4199 . \\
4559 . \\
4951 . \\
5375 . \\
5837 . \\
6337 . \\
6881 . \\
7472 . \\
8113 . \\
8809 . \\
9564 . \\
10385 . \\
11276 . \\
12244 . \\
13294 .\end{array}$ & $\begin{array}{l}10700 . \\
11449 . \\
12250 . \\
13108 . \\
14026 . \\
15007 . \\
16058 . \\
17182 . \\
18385 . \\
19672 . \\
21049 . \\
22522 . \\
24098 . \\
25785 . \\
27590 . \\
29522 . \\
31588 . \\
33799 . \\
36165 . \\
38697 .\end{array}$ & $\begin{array}{l}67016 . \\
67016 . \\
67016 . \\
67016 . \\
67016 . \\
67016 . \\
67016 . \\
67016 . \\
67016 . \\
67016 . \\
67016 . \\
67016 . \\
67016 . \\
67016 . \\
67016 . \\
67016 . \\
67016 . \\
67016 . \\
67016 . \\
67016 .\end{array}$ & $\begin{array}{r}-14121 . \\
-9138 . \\
-3689 . \\
2269 . \\
8783 . \\
15906 . \\
23221 . \\
31176 . \\
39829 . \\
49239 . \\
59473 . \\
70602 . \\
82705 . \\
95866 . \\
110177 . \\
125738 . \\
142659 . \\
161057 . * \\
181060 . \\
-634891 .\end{array}$ & $\begin{array}{r}-13075 . \\
-7834 . \\
-2928 . \\
1668 . \\
5978 . \\
10023 . \\
13549 . \\
16844 . \\
19924 . \\
22807 . \\
25507 . \\
28037 . \\
30410 . \\
32639 . \\
34732 . \\
36702 . \\
38556 . \\
40304 . \\
41954 . \\
-136215 .\end{array}$ \\
\hline & & & & & 537920 . & 239582. \\
\hline
\end{tabular}


Table V

GEOTHERMAL DEVELOPMENT CORPORATION

\begin{tabular}{|c|c|c|c|c|c|c|}
\hline $\begin{array}{l}\text { GROSS } \\
\text { SALES } \\
\end{array}$ & $\begin{array}{l}\text { DEPLETION } \\
\text { ALLOWANCE }\end{array}$ & $\begin{array}{l}\text { STRAIGHT- } \\
\text { LINE DPRCN. } \\
\text { 10\% SALVAGE }\end{array}$ & $\begin{array}{c}\text { GEOTHERMAL } \\
\text { PUMPING \& } \\
\text { MAINTENANCE } \\
\text { COSTS } \\
\end{array}$ & $\begin{array}{c}\text { NET INCOME } \\
\text { BEFORE } \\
\text { TAXES } \\
\end{array}$ & $\begin{array}{c}\text { FEDERAL } \\
\text { INCOME } \\
\text { TAXES } \\
\end{array}$ & $\begin{array}{c}\text { NET INCOME } \\
\text { AFTER } \\
\text { TAXES } \\
\end{array}$ \\
\hline $\begin{array}{r}66263 . \\
72249 . \\
78777 . \\
85896 . \\
93661 . \\
102129 . \\
110855 . \\
120326 . \\
130606 . \\
141764 . \\
153876 . \\
167023 . \\
181292 . \\
196781 . \\
213594 . \\
231842 . \\
251650 . \\
273151 . \\
296488 . \\
321819 .\end{array}$ & $\begin{array}{l}14578 . \\
14450 . \\
14180 . \\
13743 . \\
14049 . \\
15319 . \\
16628 . \\
18049 . \\
19591 . \\
21265 . \\
23081 . \\
25053 . \\
27194 . \\
29517 . \\
32039 . \\
34776 . \\
37748 . \\
40973 . \\
44473 . \\
48273 .\end{array}$ & $\begin{array}{l}75393 . \\
75393 . \\
75393 . \\
75393 . \\
75393 . \\
75393 . \\
75393 . \\
75393 . \\
75393 . \\
75393 .\end{array}$ & $\begin{array}{l}13368 . \\
14370 . \\
15449 . \\
16611 . \\
17861 \\
19207 \\
20618 \\
22133 . \\
23761 . \\
25509 . \\
27387 \\
39404 . \\
31571 \\
33899 \\
36400 \\
39088 . \\
41975 . \\
45077 \\
48411 . \\
51993 .\end{array}$ & $\begin{array}{l}-37075 . \\
-31964 . \\
-26246 . \\
-19851 . \\
-13642 . \\
-7790 . \\
-1784 . \\
4751 . \\
11861 . \\
19598 . \\
103408 . \\
112565 . \\
122527 . \\
133365 . \\
145154 . \\
157978 . \\
171928 . \\
187101 . \\
203604 . \\
221553 .\end{array}$ & $\begin{array}{r}-17796 . \\
-15343 . \\
-12598 . \\
-9529 . \\
-6548 . \\
-\quad 3739 . \\
-\quad 857 . \\
2280 . \\
5693 . \\
9407 . \\
49636 . \\
54031 . \\
58813 . \\
64015 . \\
69674 . \\
75830 . \\
82525 . \\
89808 . \\
97730 . \\
106345 .\end{array}$ & $\begin{array}{r}-19279 . \\
-16621 . \\
-13648 . \\
-10323 . \\
-7094 . \\
-4051 . \\
-\quad 928 . \\
2470 . \\
6168 . \\
10191 . \\
53772 . \\
58534 . \\
63714 . \\
69350 . \\
75480 . \\
82149 . \\
89402 \\
97292 . \\
105874 . \\
115208 .\end{array}$ \\
\hline & & & TOTAL & 112150.25 & & \\
\hline
\end{tabular}


GEOTHERMAL DEVELOPMENT CORPORATION

\begin{tabular}{|c|c|c|c|c|c|c|}
\hline $\begin{array}{l}\text { ADD } \\
\text { DEPLETION } \\
\text { AND DPRCN. } \\
\end{array}$ & $\begin{array}{l}\text { AFTER TAX } \\
\text { CASH FLOW } \\
\text { INCLUDES 25\% } \\
\text { INVESTMENT } \\
\text { TAX CREDIT } \\
\end{array}$ & $\begin{array}{l}\text { PRESENT } \\
\text { VALUE } \\
\text { AT } 7 \% \\
\end{array}$ & $\begin{array}{l}\text { PRESENT } \\
\text { VALUE } \\
\text { AT } 12.22 \% \\
\end{array}$ & $\begin{array}{c}\text { ANNUAL } \\
\text { EQUIVALENT } \\
\text { CASH FLOW } \\
\text { PROVIDED BY } \\
\text { THE PROJECT } \\
\end{array}$ & $\begin{array}{l}\text { ANNUAL } \\
\text { CASH FLOW } \\
\text { DEDUCTING } \\
\text { ROI } \\
\end{array}$ & $\begin{array}{c}\text { PRESENT } \\
\text { VALUE } \\
\text { AT } 11.8788 \% \\
\end{array}$ \\
\hline \multirow[t]{2}{*}{$\begin{array}{l}89971 . \\
89843 . \\
89573 . \\
89136 . \\
89442 . \\
90712 . \\
92021 . \\
93442 . \\
94984 . \\
96658 . \\
23081 . \\
25053 . \\
27194 . \\
29517 . \\
32039 . \\
34776 . \\
37748 . \\
40973 . \\
44473 . \\
48273 .\end{array}$} & $\begin{array}{r}280117 . \\
73221 . \\
75925 . \\
78814 . \\
82348 . \\
86661 . \\
91093 . \\
95912 . \\
101152 . \\
106848 . \\
76853 . \\
83587 . \\
90908 . \\
98867 . \\
107519 . \\
116925 . \\
127150 . \\
138265 . \\
150347 . \\
163480 .\end{array}$ & $\begin{array}{r}261791 . \\
63954 . \\
61978 . \\
60127 . \\
58713 . \\
57746 . \\
56728 . \\
55822 . \\
55020 . \\
54316 . \\
36512 . \\
37114 . \\
37724 . \\
38342 . \\
38970 . \\
39607 . \\
40252 . \\
40908 . \\
41572 . \\
42246 .\end{array}$ & $\begin{array}{r}249614 . \\
58143 . \\
53725 . \\
49696 . \\
46270 . \\
43391 . \\
40644 . \\
38134 . \\
35838 . \\
33734 . \\
21622 . \\
20955 . \\
20309 . \\
19682 . \\
19074 . \\
18483 . \\
17911 . \\
17356 . \\
16817 . \\
16295 .\end{array}$ & $\begin{array}{l}111299 . \\
111299 . \\
111299 . \\
111299 . \\
111299 . \\
111299 . \\
111299 . \\
111299 . \\
111299 . \\
111299 . \\
111299 . \\
111299 . \\
111299 . \\
111299 . \\
111299 . \\
111299 . \\
111299 . \\
111299 . \\
111299 . \\
111299 .\end{array}$ & 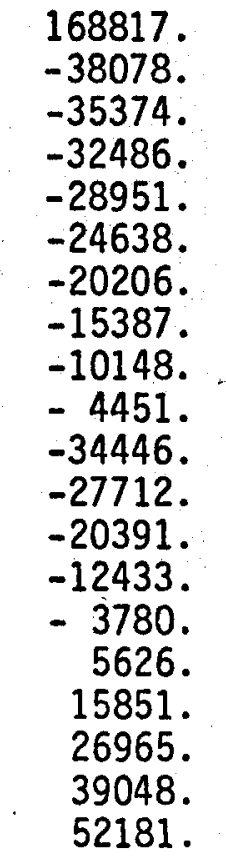 & $\begin{array}{l}250375 . \\
58498 . \\
54218 . \\
50305 . \\
46980 . \\
44192 . \\
41519 . \\
39074 . \\
36833 . \\
34777 . \\
22358 . \\
21735 . \\
21129 . \\
20539 . \\
19965 . \\
19406 . \\
18863 . \\
18334 . \\
17819 . \\
17318 .\end{array}$ \\
\hline & TOTALS & 1179442 & 837693. & & 5. & 854239. \\
\hline
\end{tabular}




\section{CHAPTER VI}

\section{LEGAL AND INSTITUTIONAL SETTING}

\section{INTRODUCTION}

This chapter provides a general guide to the regulatory framework affecting geothermal energy development. Specific details of the permitting and approval process can be obtained from the appropriate federal, state, and local agencies. If geothermal development is to proceed expeditiously, the developer-user must effectively plan for compliance with regulations and permitting procedures.

The following sections outline the general steps necessary to gain access to explore, develop, distribute, and use geothermal resources.

\section{OBTAINING ACCESS TO GEOTHERMAL RESOURCES}

\section{A. Determining Resource Ownership}

After a site for geothermal resource development has been identified, land surface and subsurface ownership must be determined. In many cases, ownership of the surface and geothermal or mineral rights is the same. However, in some instances, the geothermal or mineral estates have been severed from the surface ownership. When the estates have been separated, the potential developer will have to negotiate with both owners.

In any case, a competent title search and ownership determination is essential to secure the necessary development rights. It is best to consult a qualified attorney.

The would-be geothermal developer must identify and secure all resource rights required for the proposed project. This task is not as simple as it may appear since geothermal resources are akin to water, to gases, and to minerals. This complexity makes it difficult to relate geothermal to other established resource categories. Existing water rights, mineral titles, surface and subsurface estates form an intricate tangle, and attachment of geothermal rights to one of them will disturb the rest.

Legal definitions of geothermal resources serve to distinguish geothermal resources from other natural resources, in particular: water, dissolved gases, and minerals.

It is important to consider the legal definitions of geothermal resources at the state and federal level. The federal Geothermal Steam Act of 1970 defines geothermal resources as:

\footnotetext{
"Geothermal steam and associated geothermal resources means (i) all products of geothermal processes, embracing indigenous steam, hot water and hot brines; (ii) steam and other gases, hot water and hot brines resulting from water, gas, or other fluids artificially
} 
introduced into geothermal formations; (iii) heat or other associated energy found in geothermal formations; and (iv) any by-product derived from them."

In establishing geothermal legislation, Washington unlike many other states, did not draw heavily from the federal Geothermal Steam Act of 1970 or the California Geothermal Resources Act of 1967. The Washington definition as established in the Geothermal Resources Act of 1974 (RCW 97.76(3) states:

"'Geothermal resources' means only that natural heat energy of the earth from which it is technologically practical to produce electricity commercially and the medium by which such heat energy is extracted from the earth, including liquids or gases, as well as any minerals contained in any natural or injected fluids, brines and associated gas, but excluding oil, hydrocarbon gas and other hydrocarbon substances."

The Washington Geothermal Resources Act of 1974 further characterizes geothermal resources to be: sui generis, being neither a mineral resource nor a water resource" (RCW 97.76(4)).

The Act did not establish ownership rights to geothermal resources and it was not until the Act was ammended in 1979 that this very important question was resolved. The amendment reads as follows:

Section 1. Section 4, Chapter 43 Laws of 1974 ex. sess. and RCW 79.76. 040 are each amended to read as follows:

"Notwithstanding any other provision of law, geothermal resources are found and hereby determined to be sui generis being neither a mineral resource nor a water resource and as such are hereby declared to be the private property of the holder of the title to the surface land above the resource.

Sec. 2. If any provision of this 1979 act or its application to any person or circumstance is held invalid, the remainder of the act or the application of the provision to other persons or circumstances is not affected."

As can be clearly seen from the definition of geothermal resources, only resources capable of producing electricity are specifically defined as being geothermal. Thus, the great majority of the hydrothermal resources which will be encountered are left in the realm of water and all rules and regulations pertaining to ground water will apply.

B. Access and Development Rights

1. Private Land

Access to private land can be obtained by sale, lease, permit, option, or any other mutual agreement with the owner of the surface property and geothermal estate. If the land and resources are purchased outright, it is important that the developer secure clear title to the surface and subsurface rights. 
In most instances, access to private land is obtained through a geothermal lease. Leasing terms generally include length of lease, royalty payments, lease fees, and stipulations governing exploration and development activities. This mechanism is often based on oil and gas leasing procedures.

Landowners may permit access prior to a lease or purchase option. This allows the developer to conduct agreed upon preliminary exploration activities. Such activities could include geological and geophysical investigations which do not disturb the surface and temperature gradient hole drilling. A state well drilling permit would be required for exploratory drilling on private land.

If the area of interest is already under lease for other purposes such as farming or grazing, the developer must secure permission from the lessee for surface access rights.

Both the developer seeking access rights and the landowner interested in leasing resource title would be wise to invest in competent title assistance. In addition to this legal advice, consultation with a qualified accountant regarding royalty payments and applicable tax laws is advised.

\section{State Land}

The Board of Natural Resources has the responsibility for adopting rules and regulations for the leasing of state lands for geothermal exploration and development. Presently draft rules and regulations are being formalized and the leasing of state lands could begin as early as fall 1980.

It must be noted that any lease for geothermal resources will give the lessee right to only those resources as defined by statutes, i.e. only resources capable of producing electricity.

Information concerning leasing state land should be addressed to W.R. Hoffman, Division of Lands Management, Department of Natural Resources, $01 y$ mpia, Washington 98504.

\section{Federal Land}

The major pre-lease activities of the federal leasing process are summarized in Figure 19.

Surface access and the right to explore, develop and use geothermal resources on federal lands are acquired with a geothermal lease issued by the U.S. Bureau of Land Management (BLM). Pursuant to the Geothermal Steam Act of 1970, the Secretary of the Interior can issue leases for the development and use of geothermal resources on certain federal lands. Exempted from leasing are lands within the National Park System, national recreation areas, fish hatcheries, identified wildlife areas (e.g. refuges, ranges, management areas, waterfowl production areas), Indian lands, Department of Defense. lands, and other lands selected by the Secretary. Wilderness areas may be leased in accordance with terms of the Wilderness Act of 1964. 


\section{FEDERAL GEOTHERMAL REGULATORY PROCESS}

Principal Pre-Lease Activites
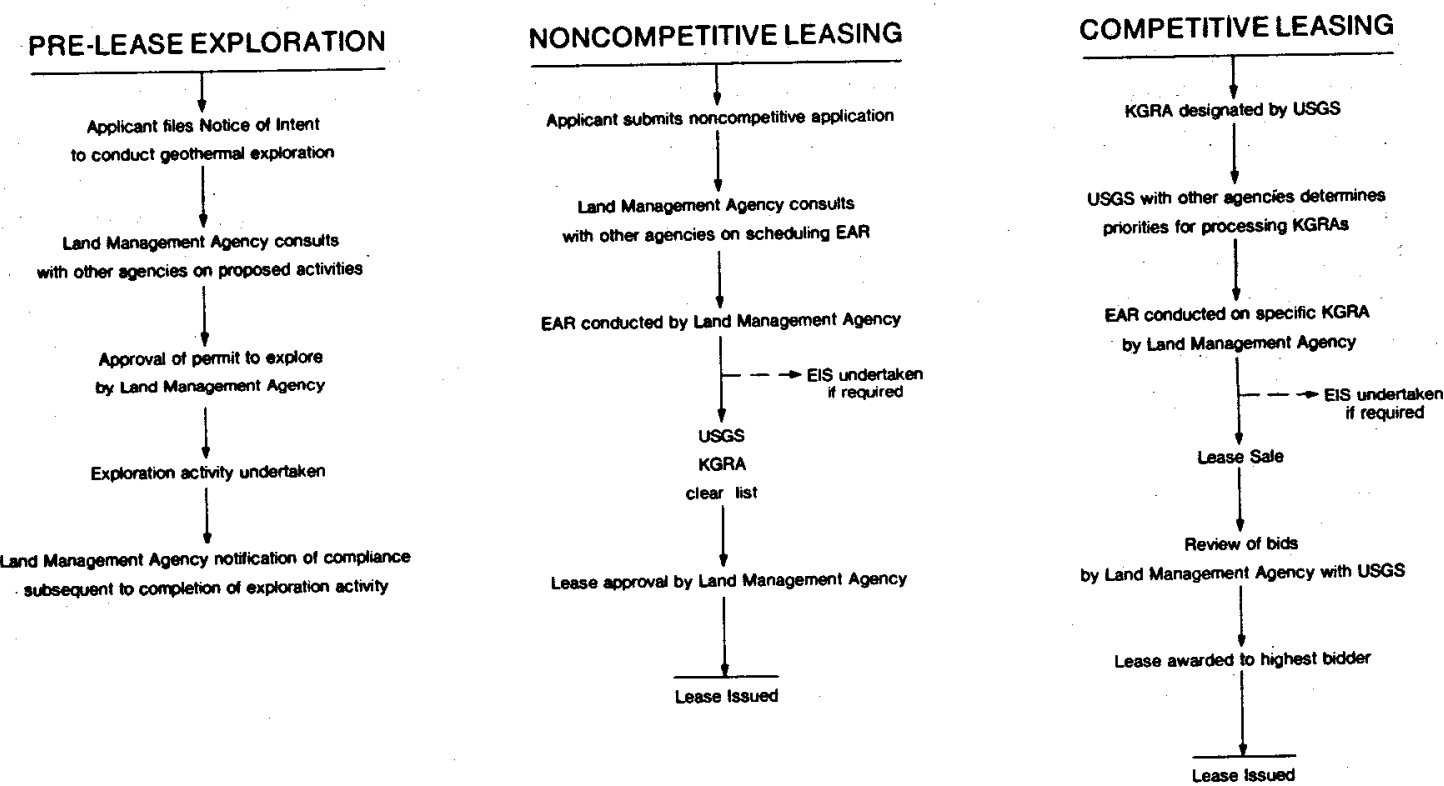

EAR - Environmental Analysis Report

EIS - Environmenta Impact Statement

EA - Environmental Anatysis

Figure 19 
Limited exploration involving casual-use activities and other prel iminary evaluation operations may be conducted before securing a lease by obtaining a temporary use permit from the local BLM District Office or the Forest Supervisor's Office. Casual-use refers to activities such as geologic mapping that are transitory and do not appreciabiy disturb the land.

Pre-lease exploration activities including test drilling up to 152 meters ( 500 feet) may begin upon approval of a "Notice of Intent and Permit to Conduct Exploration Operations" from the District Manager of the BLM, who coordinates with the USGS. The notice requires site specific information concerning exploration plans and a $\$ 5,000$ bond or other bond assurance. The approved notice requires compliance with all applicable federal and state laws and local ordinances. When the exploration activities are complete, a "Notice of Completion of Exploratory Operations" must be filed with the BLM. Similar procedures are required by the U.S. Forest Service, which issues Prospecting Permits on National Forest Lands for exploratory operations.

Casual-use and exploration under a Notice of Intent gives the nonexclusive right to conduct operations on federal land, but no preference for a lease.

The Bureau of Land Management has primary responsbility for issuing geothermal leases on all available federal lands. The U.S. Geological Survey and U.S. Forest Service also have responsibilities governing the issuance and administration of federal geothermal leases. The major role of these agencies in the federal leasing program is outlined below:

Bureau of Land Management

- Receiving and processing lease applications for noncompetitive areas.

- Publishing lease sale notices and receiving bids for competitive lands.

- Preparing environmental assessments on suitability of BLM lands for geothermal leasing purposes.

- Providing input to the USGS on surface consideration of post-lease environmental evaluations (USGS has primary responsibility for post-lease activities).

- Preparing lease stipulations governing special surface management programs.

- Supervising land uses on BLM leased land outside areas of operations.

- Awarding all leases. 
- Administering lease (except those functions assigned to the USGS or Forest Service).

USGS

- Providing input on geologic setting and geothermal operations for pre-lease environmental evaluations.

- Supervising activitiy within the area of operation on leased lands for all phases of exploration, development and utilization.

- Preparing post-lease environmental assessments on site specific exploraton and development plans. The surface management agency, BLM or Forest Service, provides input.

- Designating "Known Geothermal Resource Areas".

- $\quad$ Administering terms of lease.

- Issuing Geothermal Resource Operational Orders.

- Preparing lease stipulations.

\section{Forest Service}

- Preparing environmental assessments on suitability of natiorial forest lands for geothermal leasing purposes.

- Providing input to USGS on surface considerations of post-lease environmental evaluations.

- Preparing lease stipulations for governing surface management.

- Supervising land uses on leased land outside areas of operation.

- Issuing special use permits for surface occupancy.

The procedure for obtaining a federal geothermal lease depends upon the competitive interest classification of the land. Lands may be classified as "Known Geothermal Resource Areas" (KGRA) and leased on a competitive bid basis. Non-KGRA acreage is offered through a noncompetitive lease to the first qualified applicant.

\section{Competitive Leasing}

Lands designated by the USGS as KGRAs may only be leased through competitive bidding. In Washington 35,612 acres have been so classified. These areas are shown in Figure 1. The Geothermal Steam Act defines a KGRA as: 


\section{UNITED STATES \\ DEPARTMENT OF THE INTERIOR \\ BUREAU OF LAND MANAGEMENT}

\section{APPLICATION.TO LEASE GEOTHERMAL RESOURCES}

(Sec. 4 Noncompetitive Lease)
FORM APPROVED

OMB NO. $42-R 1688$

Serial Number

The undersigned hereby makes application to lease all or any of the lands described herein that are available for lease pursuant and subject to the terms and provisions of the Act of December 24, 1970 (84 Stat. 1566, 30 U.S.C. Sec. 1001), or any amendments hereafter enacted, hereinafter referred to as the Act. and to all applicable regulations now or hereafter in force when not inconsistent with any express and specific provisions herein, which are made a part hereof.

1. Name (Last, First, Middle initial, print or type) Address (include zip code)

Social Security or Taxpayer Number

2. Legal description

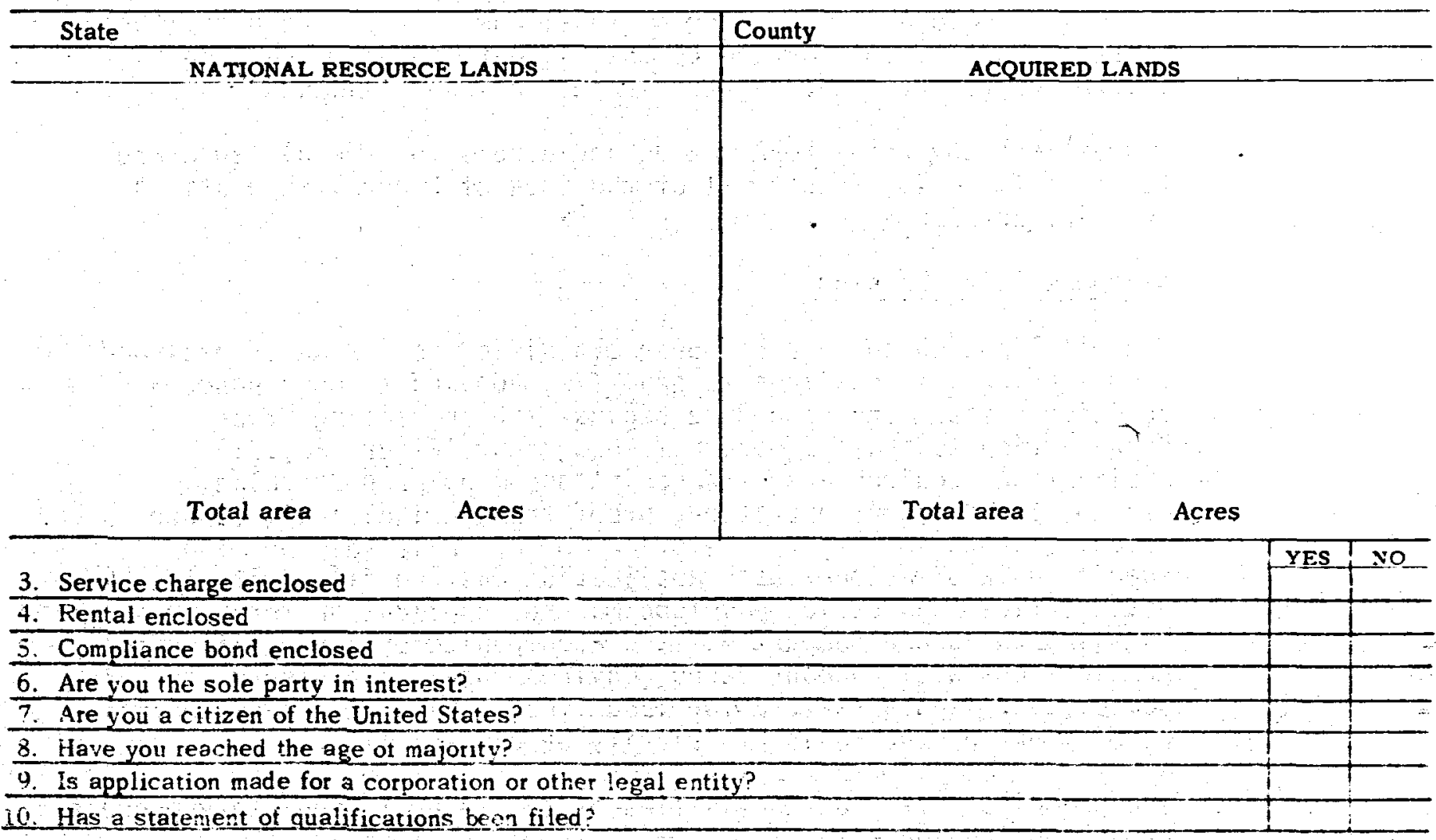

I CERTIFY That ny interests, direct or indirect, in geothermal resources leases in the above State do not exceed 20.480 acres. That the statements made herein are true, complete, and correct to the best of my knowledge and belief and are made in good taith.

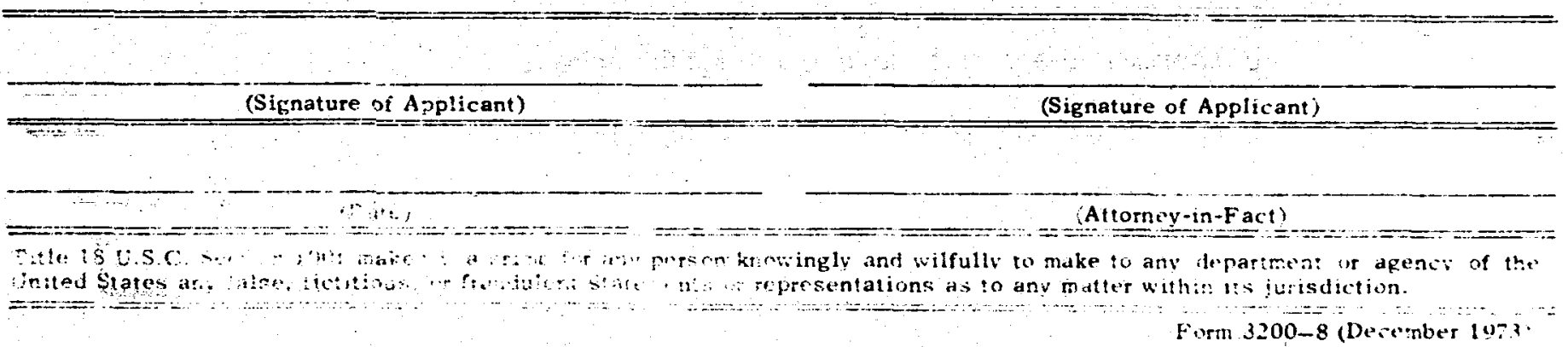


"...an area in which the geology, nearby discoveries, competitive interest or other indicia would, in the opinion of the Secretary (of Interior), engender a belief in men who are experienced in the subject matter that the prospects for extraction of geothermal steam or associated geothermal resources are good enough to warrant expenditures of money for the purpose."

Competitive interest will also exist if at least one-half of the lands in an application are covered by another application filed during the same month.

The BLM State Office manages leasing on KGRA.lands. The appropriate surface management agency, BLM or Forest Service, conducts the necessary pre-lease environmental review and determines which areas will be available for leasing. The BLM sets the lease sale date and publishes public notices. On the day of the sale, each bidder must submit a statement of qualifications for leasing and a sealed bid which includes payment for at least one-half of the bid amount. Leases generally are awarded to the highest bidder. The federal government reserves the right to reject any and all bids.

Regulations governing KGRA status and access to federal lands are found in Title 43, Chapter II of the Code of Federal Regulations (43 CRF Part 3200).

\section{Noncompetitive Leasing}

Federal lands which have not been classified as a KGRA or excluded from leasing are available to qualified applicants on a noncompetitive basis. The procedure begins with the filing of an "Application to Lease Geothermal Resources" (Figure 20). The application requires a site description, map, proposed plan, methods for diligent operation, proof that an indiviual, corporation, or municipality is qualified to hold a lease, and other specified information. Each application must be filed with the BLM State Office in a sealed envelope marked "Application for a Lease Pursuant to 43 CFR Subpart $32 "$ and accompanied by a $\$ 50$ filing fee. Applications will be considered, environmental assessments conducted, and leases awarded for lands found suitable for geothermal development on the basis of priority by date of filing.

The principal pre-lease activities of the federal regulatory process are shown in Figure 21.

Salient features of the federal lease terms include:

Lease limitations

Geothermal lease not to exceed 2,560 acres. 640 acres minimum. 20,480 acres maximum/total state holdings. 
GEOTHERMAL REGULATORY PROCESS

Pro-Loase Activitios

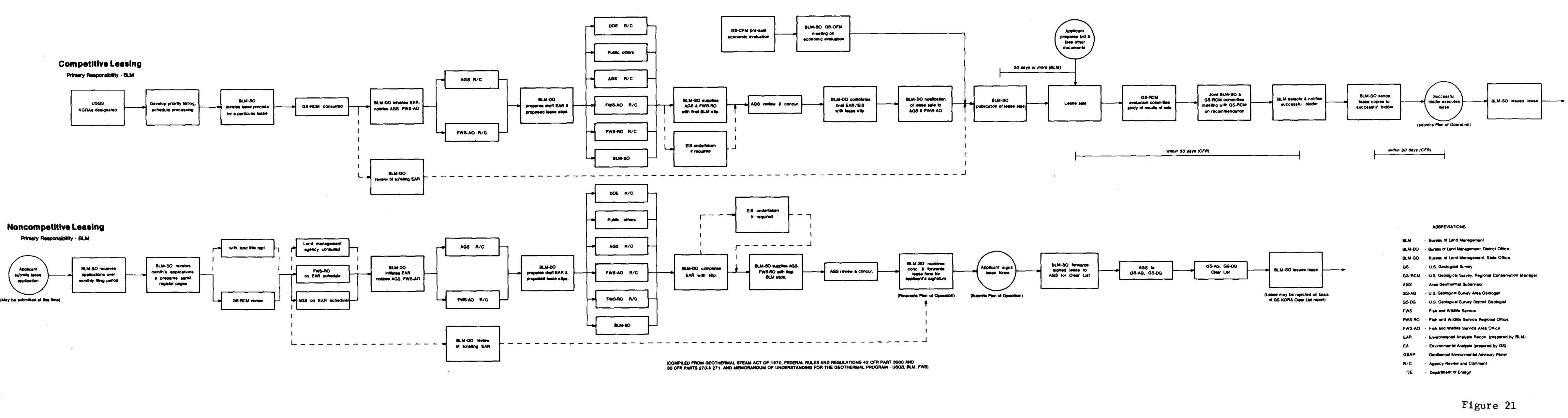


Primary term

A1] federal leases are issued for a primary term of ten years.

Lease renewal

Leases may be continued for the extent of commercial production up to an additional forty years. Leases may be renewed for a second forty-year term if commercial production continues and the acreage is not required for other use.

\section{Lease extension}

A lease that is being "diligently" drilled before the end of the primary term, will be extended for five years and for the duration of commercial production up to 35 years.

\section{Annual fees}

$\$ 1$ per acre minimum rental (exact amount set in lease).

$\$ 1$ per acre escalation annually after the fifth year, until commercial production begins.

$\$ 2$ per acre minimum during production.

Exploration expenditures during the first five years, and those subsequent years, may be credited to the escalated portion of rent dure.

\section{Royalties}

- 10 percent minimum and 15 percent maximum of the value of geothermal production.

- 5 percent maximum of the value of any by-product produced.

- 22 percent maximum royalty.

Pending legislation

It is important to note that pending federal legislation may significantly alter the leasing process for public lands. For example, KGRA designations may be limited to prospects with electrical generation capabilities.

\section{Information}

For additional information, copies of applicable rules and regulations, and application forms, contact:

Bureau of Land Management

Minerals Leasing Section

729 NE Oregon Street

Portland, OR

(503) 231-6291 
U.S. Forest Service

Regional Office

Mineral Leasing Section

319 SW Pine

Portland, $O R$

(503) $221-2877$

U.S. Geological Survey

Office of the Area Geothermal Supervisor

345 Middlefield Road

Menlo Park, CA 94025

(415) 323-8111

\section{EXPLORATION AND DEVELOPMENT REGULATIONS}

When clear title has been secured for a particular geothermal resource area, exploration and development should follow. Before initiating any activity the geothermal developer must obtain the necessary permits from the appropriate local, state, and federal regulators. The length of permit application review time and the number and type of permits required will vary depending upon the size of the project and the environmental sensitivity of the area. For example, a commercial geothermal greenhouse will require fewer permits and less processing time than a geothermal electric generating facility sited on federal land.

The following section describes the general types of permits that may be required. It is suggested that the developer contact the local, state, and federal agencies which may have regulatory authority for a specific project for additional details. The Washington State Energy Office can also provide information regarding permitting requirements for a particular project.

\section{A. Private Land}

The following types of permits may apply to a geothermal project:

- Conditional land-use permits may be required from cities or counties to comply with local zoning ordinances. Contact the local planning department for information regarding applicable laws and regulations.

- Construction permits and building inspections to insure compliance with state and local codes should be coordinated through the local building and safety division.

- Drilling permits will be required from the Division of Geology and Earth Resources, or the Department of Ecology, depending on expected well temperature.

- A permit is required from the Department of Ecology (DOE) for disposal of liquid wastes. 
- Other permits may be required from the Department of Ecology or regional air pollution control authorities to set limits on air emissions and fluid discharges. Contact the state DOE office for specific information.

\section{B. State Lands}

When a lease has been issued, exploration and development activities are subject to state, federal, and local regulations governing land use, well drilling, facility siting, and waste disposal, as outlined in the preceding section.

\section{Federal Lands}

When BLM has issued the lease, the U.S. Geological Survey assumes primary responsibility for exploration and develpment operations on federal land, with the exception of BLM's lead role in siting and licensing of large scale facilities. The USGS Conservation Division Area Geothermal Supervisor maintains regulatory control pursuant to the Geothermal Resources Operational Orders.

Figure 22 highlights the major post-lease regulatory steps for federal lands.

Activities related to geothermal resource exploration, development, production and utilization are carried out under a Plan of Operation approved by the Area Geothermal Supervisor. Necessary permits and environmental reviews are coordinated by the Area Supervisor with the exception of permits required for emissions to the atmosphere and waste disposal which are issued by the Department of Ecology. The developer must also obtain a well drilling permit from the Divison of Geology and Earth Resources. Plans of operation may be submitted sequentially by development phases or in combination, depending upon project scale and developer's data.

The principal post-lease activities of the federal regulatory process are shown in Figure 23.

\section{Environmental Review Procedures}

Federal agencies, generally the surface management agency and the USGS, are responsible for the preparation of environmental documents necessary to satisfy requirements of the National Environmental Policy Act and state or local environmental laws for activities conducted on federal land. State and local regulations are applicable to federal lands, but these standards are generally enforced by federal agencies. It may be necessary for the developer to provide specific data and to conduct an archaeological survey.

Environmental impact evaluation is required for all "major federal actions significantly affecting the quality of the human environment." The level of environmental evaluation will vary depending on the scope of the proposed activity. Large-scale developments will usually require a formal Environmental Impact Statement (EIS) including a public hearings process. These reports are prepared by 


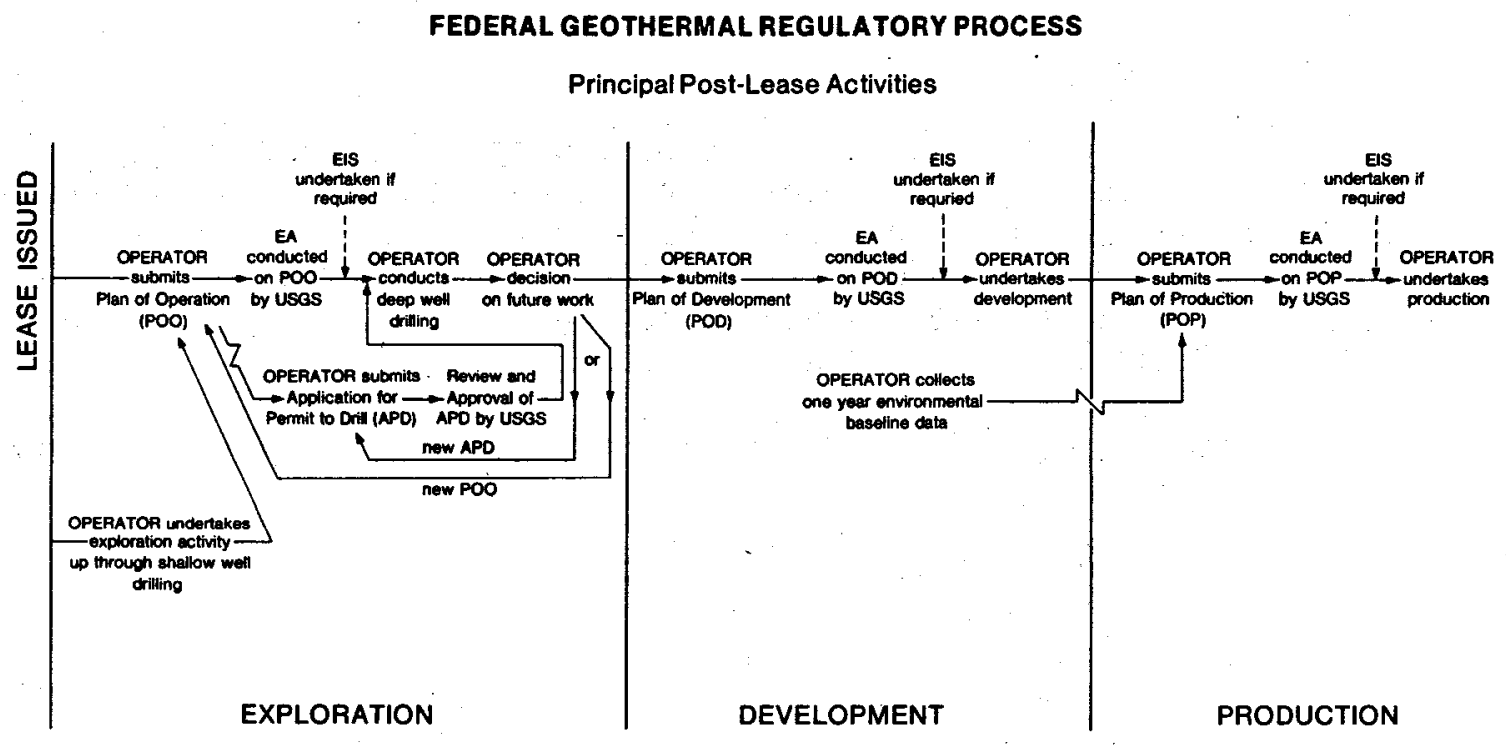

Figure 22 


\section{Post-Lease Activities}
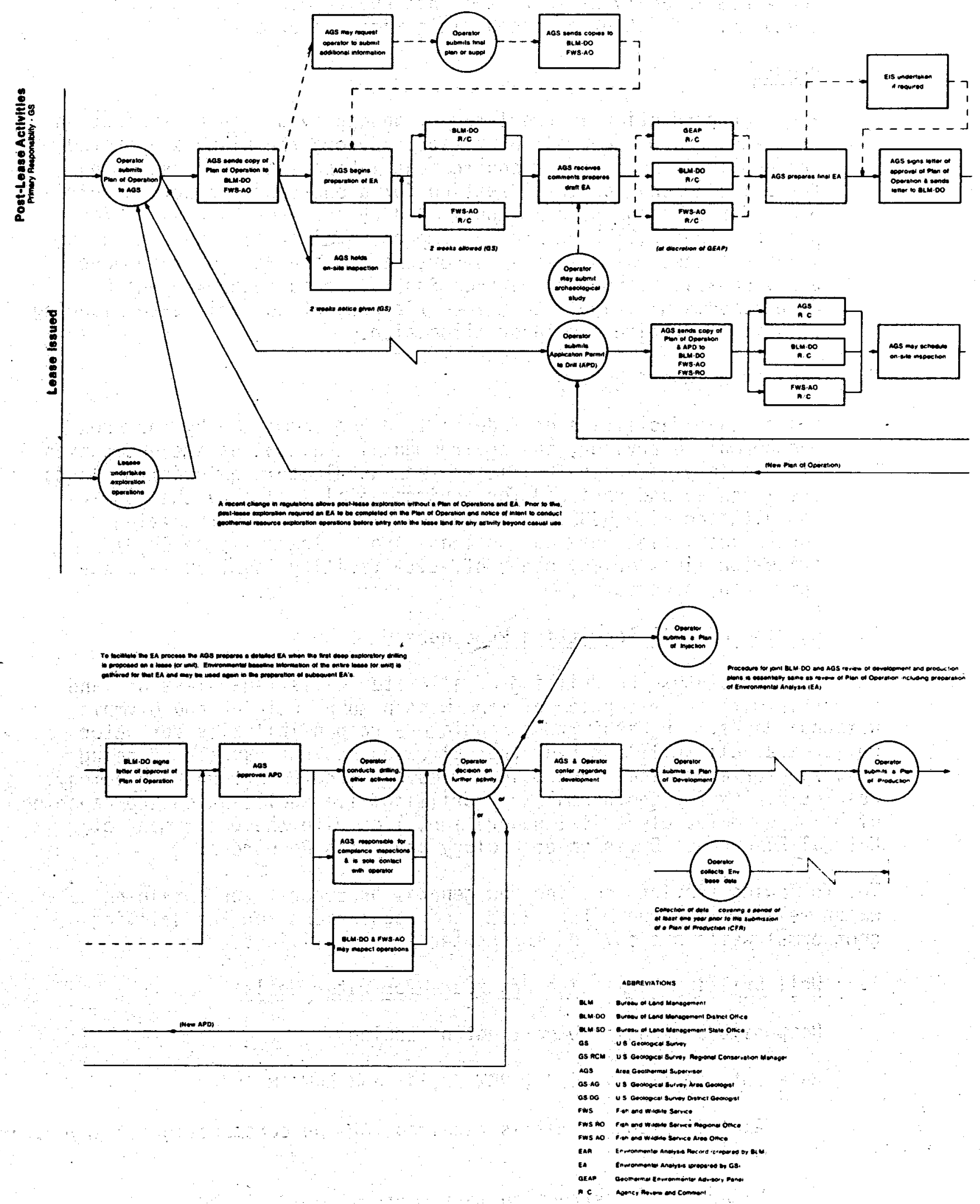
the relevant federal agencies, usually at no cost to the developer. However, they may require information from the lessee, and adequate time for the preparation and review process needs to be allocated by the developer. Small scale projects may not require a full scale EIS if analyses shows that net environmental impacts are adequately offset by proposed mitigating measures.

2. Production

Resource production is regulated by an approved Plan of Production from the Area Geothermal Supervisor. Before the plan is approved, the applicant must gather environmental baseline data describing the existing environmental setting for a one-year period. Requirements for baseline data may be waived by the Area Supervisor for projects that will have minimal impact. Waivers are determined on a case-by-case basis. It is important for the developer to have early consultation with the Area Supervisor to determine which requirements will apply to a specific project to facilitate planning of sufficient time and labor allocation.

3. Facilities Construction

Small scale facilities on federal land are permitted by the Area Geothermal Supervisor, and environmental evaluations are undertaken if necessary. Larger facilities such as electric generating plants are licensed and reviewed for environmental impact by the BLM in consultation with USGS. The basic permit for facility siting covers activities only on the lease area. Transmission or distribution lines or any other off-site facility involves separate permitting procedures.

\section{Washington Well Permitting Procedures}

The state regulates the drilling of all water wells regardless of land ownership with the exception of land within Mount Rainier and 0lympic National Parks. In Washington, regulatory responsibilities for water wells, i.e. all wells for hydrothermal resources not capable of being utilized for electrical generation, lies with the Department of Ecology. Responsibility for geothermal well drilling, i.e. wells which are capable of being used for electrical generation, lies with the Department of Natural Resources, Division of Geology and Earth Resources.

The following sections outline the general procedures for obtaining water well drilling permits. Rules and regulations for the drilling of geothermal wells are covered in Chapter III - Drilling.

1. Well Drilling Permitting Procedure for Water Wells

Responsible agency: Department of Ecology

Relevant laws: RCW 90.44, RCW 90.14, and RCW 18.104

- A water right permit is required for the construction of any water well.

- Water well construction must conform to RCW 18.104. 
- A permit is required for the withdrawal of all ground water except: (1) for stock watering purposes, or (2) for the watering of a lawn or of a noncommercial garden not exceeding onehalf acre in area, or (3) for single or group domestic uses in amounts not exceeding five thousand gallons a day, or (4) for an industrial purpose in an amount not exceeding five thousand gallons a day (RCW 90.40 .050$)$.

\section{E. Geothermal Fluid Disposal}

Washington policy, as established in RCW 97.76, states that all geothermal fluids shall be injected into the same reservoir from which it is withdrawn unless authorization for secondary use of by-product water resources for beneficial use is obtained from the Department of Ecology through the water appropriation procedure.

Presently the Department of Ecology is reviewing rules and regulations for injection of hydrothermal fluids. In addition, the Department of Natural Resources Division of Geology and Earth Resources is considering the need to modify present injection law to allow for a site-by-site evaluation dependent upon the characteristics of the geothermal fluid.

\section{F. Water Rights}

All ground waters of the state are declared to be public ground waters and belong to the public and are subject to appropriation for beneficial use (RCW 90.44.040).

Water appropriations follow the doctrine of first-in-time, first-inright, so the geothermal developer should be concerned about the availability of a water right of sufficient quantity to satisfy the needs of a project. If waters in an area have been fully appropriated, the developer may be able to obtain water rights by providing replacement supplies or purchasing rights from existing users.

\section{G. Facility Siting}

The Washington Energy Facility siting Evaluation Council (EFSEC) maintains siting jurisdiction for certain energy facilities on all lands, private and state owned. RCW 80.50 .060 applies to the construction of energy facilities which includes the new construction of energy facilities and the reconstruction or enlargement of existing energy facilities. However, the EFSEC process would not apply to a geothermal facility unless:

- The on-site improvements exceed $\$ 250,000$, and

- The generating plant has a capacity of 250 thousand kw or more.

\section{DISTRIBUTION AND USE}

The final phase of geothermal development is to provide for use of the resource. The extent of regulations governing transport and use of geothermal energy are proportional to the scale of the end-use. An 
investor-owned utility selling electricity must comply with the most comprehensive set of regulations while a one-we11/one-home heating system represents the low end of the regulatory continuum.

Homeowners, who propose to use a geothermal well situated on their own property for space heating, are subject to focal regulations governing land use and code enforcement. In some areas, such as Klamath Falls, Oregon, local entities are developing geothermal management ordinances, whereby new wells will have to comply with city regulations. Developers should contact city or county governments to determine applicability of zoning ordinances and identify necessary permits such as construction and plumbing permits.

Most other types of development include a distribution system that will require obtaining the right to cross many parcels of property. Transportation corridor selection will depend on the user's ability to secure rights-of-way. Outright purchase of property is one option. Systems intended for public use, such as a municipal district heating system, may be able to exercise the power of eminent domain to purchase private land for pubic benefit. Both public and private users can gain the limited right to access by obtaining an easement from the property owner. Easements along existing rights-of-way, such as highways and railroads, are obtained from the appropriate government agency or private owner.

Geothermal developments on all lands involving high voltage transmission lines (in excess of 200,000 volts) require site certificates from the Washington Energy Facility Siting Evaluation Council. EFSEC authority over the site continues during operation. Federal authorities are responsible for regulating electric transmission lines which are a part of the northwest power grid.

Geothermal resources developed on federal leases require permits or licenses to transmit power or transport fluids. Authorizations are issued by the BLM under provisions of the Federal Land Policy and Management Act. Land use policies of the surface management agency and environmental assessments are considered in the permitting process.

All types of land uses must conform to local regulations, including zoning ordinances, comprehensive land use plans and building, plumbing and electrical codes.

When a system is in operation, financial considerations also come into effect. If development has taken place on leased land, royalty payments will be initiated. Utility service provided for electric or direct heat use will be subject to regulations by the Utility and Transportation Commission. The Department of Ecology may also impose regulations to govern a facility's operation to protect the public interest.

\section{INFORMATION, ASSISTANCE AND INCENTIVES}

\section{A. Information Sources}

Information regarding geothermal development and use is available from a variety of public and private sources. Federal and state agencies 
responsible for alternate energy planning, development and regulation can provide information concerning technical, economic, institutional aspects, and financial support for geothermal development and use. Local sources of information include universities, planning departments, area economic development groups, the Energy Extension Service, and local energy centers. Private consultants can also provide valuable assistance ranging from resource identification to project engineering. It is suggested that initial contact be made with the Washington State Energy Office and U.S. Department of Energy to determine the most appropriate sources of information. Several of the key contacts are listed below:

\title{
U.S. Department of Energy (U.S. DOE)
}

U.S. DOE administers programs which deal with all aspects of geothermal energy from research and development to construction of demonstration projects. National programs are managed from U.S. DOE headquarters in Washington, D.C. The DOE regional representative's office in Seattle administers many of these programs in the Pacific Northwest.

\author{
U.S. Department of Energy \\ Division of Geothermal Energy \\ 12th and Pennsylvania NW \\ Federal Building \\ Washington, D.C. 20461 \\ (202) 633-8106
U.S. Department of Energy
Geotherma1 Program
Federal Building 1910
916 2nd Avenue
Seattle, WA 98174
(206) $442-2820$

\section{Washington State Energy Office (WSEO)}

WSEO administers a state program to promote commercialization of geothermal resources. WSEO can provide information and assistance concerning resource areas, development status, incentives and funding sources, technical data on resource applications, and the legal and institutional framework which guides development.

\author{
Washington State Energy Office \\ Geothermal Program \\ 400 East Union \\ OIympia, WA 98504 . \\ (206) 754-0700
}

Oregon Institute of Technology - Geo-Heat Utilization Center

The Geo-Heat Utilizaton Center manages a variety of geothermal programs which emphasize direct heat applications. These efforts include regional planning, technical assistance, market studies and outreach activities. The Center publishes a quarterly bulletin which highlights current 
activities and technologies in the geothermal direct use field. Information is available concerning planning, permitting, construction, economics and resource evaluation, and current development status for direct use applications at the state, national, and international level.

Geo-Heat Utilization Center
Oregon Institute of Technology
Klamath Falls, OR 97601

(503) 882-6321 Ext. 267

Washington Division of Geology and Earth Resources (DGER)

The Department participates in a geothermal program with the U.S. DOE and U.S. Geological Survey to assess geothermal resource areas in Washington. DGER can provide valuable information concerning resource characteristics and drilling permit procedures.

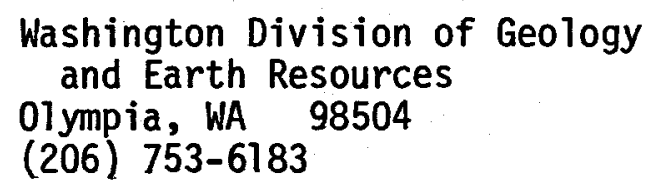

Geothermal Resources Council (GRC)

The GRC is a non-profit professional organization dedicated to information dissemination and support of geothermal education programs. GRC offers seminars and technical training sessions, and publishes special reports, a monthly bulletin and a directory. GRC can provide references and contacts for all aspects of geothermal development and use.

Geothermal Resources Council

P.0. Box 98

Davis, CA 95616

(916) $758-2360$

\section{B. Technical Assistance}

As a part of the U.S. Department of Energy's geothermal program, technical assistance, is available, at no cost, to private, public, or corporate entities interested in using geothermal resources. The program is intended to provide assistance to persons with little or no experience in the geothermal field in order to promote rapid development of geothermal energy. The amount of assistance is limited in order to protect the interests of private organizations involved in geothermal activities. Assistance is provided, as requested, on a first-come, first-served basis.

The Geo-Heat Utilization Center can provide assistance in the form of limited resource evaluation, engineering and economic feasibility studies, materials selection, corrosion problems, conceptual design, institutional factors, and consultation with private engineers and consulting geologists.

Geo-Heat Utilization Center

Technical Assistance Program

Oregon Institute of Technology

Klamath Fal1s, OR 97601

(503) 882-6321 Ext. 267 
In a similar manner, the University of Utah Research Institute can provide service for geologic, geophysical, and other resource evaluation assistance.

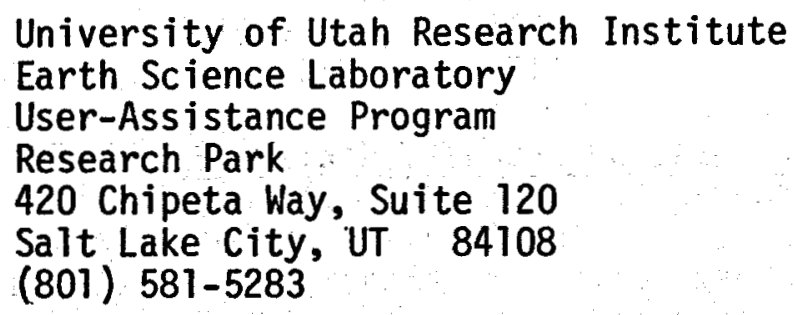

\section{Funding Opportunities}

The most direct method to fund geothermal projects is to secure private financing through lending institutions, investment companies and individual investors. Since most financial organizations have had little experience in dealing with alternate energy development projects, it is essential that the developer be knowledgeable of all aspects of resource utilization and present a comprehensive management and development plan.

Government funding opportunities are limited and competition for available funds is keen. Several of the sources listed below are earmarked specifically for geothermal projects, others are standard public works and economic development programs available to state and local governments and private entities which may be available for moderate-to-large scale geothermal development projects.

\section{Federal Programs}

\section{U.S. Department of Energy}

- Geothermal Loan Guarantee Program - The program offers loan guarantees for up to 75 percent of project costs to encourage public and private sectors to accelerate geothermal resource development by minimizing the lender's financial risks.

U.S. Department of Energy

Geothermal Loan Guarantee Program

San Francisco Operations office

1333 Broadway

Oakland, CA 97612

(415) 273-7151

- Program Research and Development Announcement (PRDA) - The PRDA program offers funding for engineering and economic feasibility studies of direct applications for specific sites. Proposals may be submitted in response to specific announcements, generally issued annually, by all sectors except federal agencies and national laboratories. Specific requirements are stipulated for each PRDA which may limit the scope of study to a particular area such as industrial processing or district heating. 
U.S. Department of Energy

San Francisco Operations Office.

Geothermal Division

1333 Broadway

Oakland, CA 94612

(415) 223-7943

- Program Opportunity Notice (PON) - Funding is provided under the PON program to accelerate the near-term commercialization of direct applications by cost-sharing the development and construction of demonstration projects. Private and public interests can qualify. PON announcements are usually released annually and may be directed to a specific area such as industrial development.

Contact the Oakland office of the U.S. DOE.

- User-Coupled Confirmation Drilling Program - The confirmation drilling program will cost-share expenses for exploration to site drill holes, drilling, flow testing, reservoir engineering, and injection well drilling for direct heat applications. The federal percentage of the cost-share will be determined by a negotiated formula based upon the degree of success of the confirmation project. Private individuals, businesses, state and local governments can offer proposals under this program.

This new program will be initiated by a Solicitation for Cooperative Agreement (SCA) in May 1980. Proposals are to be submitted within a 60-day period. Additional SCAs will be issued in the near future, but exact schedules have not been set.

\author{
U.S. Department of Energy \\ Geothermal Divsion \\ User-Coupled Confirmation Drilling Program \\ 550 2nd Street \\ Idaho Falls, Idaho 83401 \\ (208) 526-1669
}

- Appropriate Technology Grant Program - The AT Grant Program offers grants to support small scale technologies for energy conservation and renewable resource development. Grants are available to individuals, nonprofit organizations, small businesses, state and local governments, and Indian nations.

Appropriate Technology Small Grants Program U.S. Department of Energy

Federal Building 1910

916 2nd Avenue

Seattle, WA 98174

(206) $442-2820$

$\mathrm{OR}$

Washington State Energy Office

400 East Union, 1st Floor

Olympia, WA 98504

(206) $754-0700$ 
- Institutional Buildings Grants Program - The program provides funding on a cost-shared basis for schools, hospitals, local governments and public care facilities to conduct technical assistance studies for energy conservation and alternative energy development. Schools and hospitals are eligible to receive funds for implementation of capital improvement projects recommended by the technical studies.

Contact the Seattle office of U.S. DOE or the Washington State Energy Office.

In addition to these U.S. DOE programs, unsolicited proposals may be accepted, and specific solicitations to fill immediate program needs may be issued at various times. Contact the Seattle office of U.S. DOE or
U.S. Department of Energy
Division of Geothermal Energy
12th and Pennsylvania NW
Federal Building
Washington, D.C. 20461
(202) $633-8106$

Farmers' Home Administration

- Businessess and Industrial Development Loans and Grants - The program provides assistance to organizations or individuals in rural areas to improve, develop or finance business, industry and employment in order to improve the economic and environmental cl imate through loan guarantees and project grants.

- Community Facility Loans - Insured loans are available to public entities and non-profit organizations in rural areas with populations less than 10,000 to construct or expand community facilities which provide essential services.

\author{
Farmers' Home Administration \\ 1220 SW 3rd \\ Portland, $O R$ \\ (503) $221-2731$
}

Economic Development Administration

- Public Works and Development Facilities - Assistance is provided to public and nonprofit groups through grants and direct loans to promote growth and expansion of private sector industry through public works and development facilities grants in EDAdesigned areas to alleviate unemployment.

- Business Development Loans - The program offers direct loans and guarantees not available from private sources to assist businesses in preserving or expanding employment opportunities, or expanding/constructing new facilities. 
Economic Development Administration

1700 West Lake North

Seattle, WA 98109

(206) $442-47401$

Department of Housing and Urban Development

- Community Development Block Grants - Grants are available to large and small cities to help alleviate physical and economic distress through stimulation of private investment and community revitalization in areas with population outmigration or a declining tax base. Funds may be applied to projects such as housing and neighborhood conservation, local development corporations, and financing commercial or industrial building construction. Small cities with populations of less than 50,000 that are not in urban counties can apply for funds for construction and improvement of public works facilities.

- Urban Development Action Grants - Cities and urban counties in HUD-designated areas can qualify for project grants to enhance economic revitalization. Project grants aim to stimulate new development and investment in distressed areas through public and private sector financial partnerships.

Department of Housing and Urban Development 1321 2nd Avenue Federal Building Seattle, WA 98174 (206) $442-5352$

\section{Regional Programs}

The Pacific Northwest Regional Commission has provided funds for geothermal energy studies in the past. Contact PNRC for information on current programs.

Pacific NW Regional Commission

Program Coordinator Washington State Energy Office 400 East Union

01 ympia, WA 98504

(206) $754-0700$

D. Incentives

1. Federal

Residential income tax credits are available for geothermal energy expenditures. The credit is 40 percent of the cost of geothermal equipment up to $\$ 10,000$ for a maximum credit of $\$ 4,000$.

Businesses may qualify for a 15 percent investment energy tax credit for geothermal equipment, in addition to the regular 10 percent investment credit. 
Private geothermal developments may be able to deduct intangible drilling costs and make allowances for percentage depreciation.

Contact the local Internal Revenue Service for additional information.

2. $\quad$ State

Washington statutes allow the Utilities and Transportation Commission to grant an additional two percent return on investments to utilities regulated by the UTC for projects which produce energy from geothermal and other renewable resources (RCW 80.28). Public utilities may deduct any income derived from energy produced from geothermal and other renewable resources from income upon which utility taxation is based (RCW 82.16) (1980 Regular Session, House Bill 1419). 


\section{SELECTED REFERENCES}

Allen, E.M., 1980, Legal and Institutional Factors, unpublished report to the Oregon Geothermal Task Force.

Anderson, D.N., and Lund, J.W., eds., 1979, Direct Utilization of Geothermal Energy - A Technical Handbook, Geothermal Resources Council Special Report No. 7, Davis, California.

Beeland, G.V., Sebran, D.J. and Whiteright, D.K., 1978, Geothermal Development on Federal Lands - the Impediments and Potential Solutions: U.S. Department of Energy TID-28270.

Bloomquist, R.G., 1979, Geothermal Resources in Washington - Site Data Base and Development Status: Geo-Heat Utilization Center, Oregon Institute of Technology, Klamath Falls, Oregon.

Geothermal Resources Council, 1979, Geothermal Resources and the Institutional Maze: proceedings, Management Survey Course No. 1, Davis, California.

Hammer, G.D., Esposito, L., and Montgomery, M., 1979, Idaho Geothermal Handbook: Idaho Office of Energy, Boise, Idaho.

Lyons, T., 1977, Geothermal resources leasing program - administrative requirements for development of geothermal resources: Geothermal Energy Magazine, November 1977.

Petroleum Information Corporation, 1979, The Geothermal Resource: Denver, Colorado.

Sacarto, D.M., 1976, State Policies for Geothermal Development: National Conference of State Legislatures, Denver, Colorado. 
ACTIVE FAULT. A fault along which measurable displacement has occurred in comparatively recent geologic time (usually late Quaternary or Holocene). Less than .5 million years.

ACTIVE SEISMIC METHOD. Uses explosives to produce acoustic waves which are reflected and refracted through the earth and recorded by arrays of sensitive pick-ups (geophones); geologic structure is inferred from the recorded signals.

ALEUTIAN ISLANDS. A young volcanic island chain that extends westsouthwest off the south western tip of Alaska.

ANDESITE. A fine-grained igneous rock with no quartz or orthoclase, composed of about $75 \%$ plagioclase feldspars and $25 \%$ ferromagnesium silicates. Important as lavas, possibly derived by fractional crystallization from basaltic magma; widely characteristic of mountain making processes around the Pacific Ocean.

ANOMALY. 1: In geology, a local feature distinguishable in a geophysical, geochemical, or geobotanical measurement over a larger area. $2:: a$ feature considered capable of being associated with commercially valuable deposits.

AQUICLUDE, An impermeable strata that acts as a barrier to the flow of ground water.

AQUIFER. A water bearing stratum of permeable rock, sand, or gravel.

ARTESIAN. Ground water that has sufficient hydrostatic head to rise above its aquifer, but which does not necessarily rise to or above the surface of the ground.

ARTESIAN WELL. A well that penetrates an aquifer containing water with sufficient pressure to rise above the local ground level.

AUGER. A drilling tool designed so that during the drilling operation, the cuttings are carried continuously to the top of the hole by helical grooves on a rotating drill pipe.

$\underline{B}$

BALNEOLOGY. Science of the healing qualities of baths, especially natural mineral waters; the therapeutic use of natural warm of mineral waters.

BASALT. Designates a volcanic rock low in silica, and rich in iron and magnesium. By far the most abundant of all types of lava in the earth's crust.

BASEMENT. Geologic basement is the highest surface beneath which sedimentary rocks are not found; i.e., igneous or metamorphic rock underlying sedimentary rocks. 
BED ROCK. A general term for the rock, usually solid, that underlies soil or other unconsolidated, superficial material.

BINARY CYCLE. In geothermal power-plant design, denotes the use of a heat exchanger to conduct heat from a geothermal brine to the working fluid (low-boiling point fluid such as isobutane) which drives a turbine.

BIPOLE-DIPOLE MAPPING. Electrical method of geophysical exploration. Current flow is established in the earth by using a pair of source electrodes; the electric field is determined by observing the voltage drop between two pairs of electrodes oriented approximately at right angles.

BLOWOUT. The sudden, often explosive escape of steam and perhaps hot water from a geothermal well; may be caused by improper drilling procedures or rupture of casing and well-head equipment.

BLOWOUT PREVENTER. A device used to prevent the escape of $0 i 1$, water, or gas when a pressurized pocket is penetrated by a drill.

BOILING POINT. The temperature at which the vapor pressure of a liquid is equal to the pressure of the atmosphere on the liquid.

BOREHOLE. A hole drilled into the earth, often to a great depth, as a prospective oil well or for exploratory purposes.

BRINES. A highly saline solution. A solution containing appreciable amounts of $\mathrm{NaCl}$ and other salts.

BRITISH THERMAL UNITS (BTU). The quantity of heat required to raise the temperature of $1 \mathrm{lb}$. of water $7^{\circ} \mathrm{F}$ at or near its point of maximum density; a unit of energy equal to .000298 kilowatt-hour, or 252.0 calories.

$\underline{\mathrm{C}}$

CALORIE. The amount of heat needed to raise the temperature of one gram of water from $3.5^{\circ}$ to $4.5^{\circ} \mathrm{C}$.

CAP ROCK. A comparatively impervious stratum that prevents the circulation of heat or fluids.

CASCADES. A volcanic mountain chain running north south and extending from central northern California to central southern British Columbia.

CASING. A heavy pipe or tubing of varying diameter which is driven or lowered into a borehole during or after drilling in order to support the sides of the hole and thus prevent caving and loss of produced fluids which could contaminate near-surface potable water. Also used to prevent unwanted gas, water, or other fluid from entering the hole from other than the producing aquifer.

CELSIUS. A thermometric scale in whcih the melting point of ice is zero and the boiling point of water is 100 degrees above zero $\left({ }^{\circ} \mathrm{C}=\left({ }^{\circ} \mathrm{F}-32\right)\right.$ $5 / 9)$. 
CHEMICAL GEOTHERMOMETER. A technique used in exploration to assess the temperature characteristics of a geothermal reservoir. Most widely used geothermometers are the $\mathrm{SiO}_{2}$ content and $\mathrm{Na}, \mathrm{Ca}$, and $\mathrm{K}$ ratios measured in water samples.

COLLAR (DRILL). The mouth or open end of a drill hole; the rock surrounding the mouth of a borehole.

CONDENSER. A device for reducing gases or vapors to liquid or solid form.

CONDUCTION. In thermodynamics, the transference of heat through a medium or body driven by a temperature gradient and involving no macroscopic particle motion.

CONNATE WATER. Water trapped in the pore spaces of sediments at the time of deposition.

CONTOUR MAP. A map showing the configuration of the surface by means of lines connecting the points that have the same elevation.

CONVECTION. A process of mass movement in a fluid medium (gas, liquid, or plastic solid), in which cooler, denser material settles, and lighter, hotter material rises, causing vertical, near-circular flow. The process thus moves both the medium and the heat.

CORE HOLE. Any hole that is made for the purpose of obtaining core samples, e.g. a well drilled for information only, or a borehole made by a core drill.

CORROSION. A process in which a solid (usually a metal) is eaten away by a fluid (usually an acid).

CRUST. The outermost layer of the earth, composed of relatively cool, brittle, low-density rocks (compared with the mantle), and ranging in thickness from 5 kilometers (beneath the ocean floors) to 30 to 50 kilometers (under continents).

$\underline{D}$

DARCY. A unit of permeability. The unit of the darcy is $\mathrm{g}-\mathrm{cm} / \mathrm{atm}-\mathrm{s}$ since in Darcy's equation, Tength is in $\mathrm{cm}$, pressure in atmospheres, mass in grams, fluid flow in $\mathrm{cm}^{3} / \mathrm{s}$, and viscosity in centipoise $=0.01$ dyne-s $/ \mathrm{cm}^{2}=0.01 \mathrm{grm} / \mathrm{cm}-\mathrm{s}$.

DEGREE DAYS. The difference between the daily average temperature $\left({ }^{\circ} \mathrm{F}\right)$ and some arbitrary temperature such as $65^{\circ} \mathrm{F}$. Degree days are used to indicate patterns of diviation from a given temperature standard.

DIKE. A tabular body of igneous rock that cuts across the structure of adjacent rocks or cuts massive rock. Although most dikes result from the intrusion of magma, some are the result of metamorphic processes.

DIPOLE-DIPOLE. A type of resistivity survey in which the transmitting and receiving dipoles are of the same length (i.e., electrodes spaced equally and wherein the receiving-dipole stations are located at regular intervals along a line perpendicular to and bisecting the transmitting dipole. 
DRILLING MUD. A suspension, generally aqueous, used in rotary drilling. It is pumped downward through drill pipe to seal off porous zones and to counter-balance the pressure of oil, gas, and water. It also serves to cool the drilling bit and to bring cuttings to the surface.

DRILL PIPE. Pipe to which the bit is attached and which is rotated by a drill. Drilling fluid circulates through the pipe.

DRY ROCK. Rocks beneath the earth's surface that do not have meteoric or juvenile water supplied to them by an aquifer or any other source.

DRY STEAM. Steam without entrained liquid water, i.e., pure steam.

$\underline{E}$

EFFICIENCY. The ratio of the useful energy output of a machine or other energy-converting plant to the energy input.

EFFLUENT. 1: Something that flows out, as an outflowing branch of a main stream or lake. 2: Waste material (as smoke, liquid industrial refuse, or sewage) discharged into the environment, especially when serving as a pollutant.

ENERGY. The ability to do work, expressed in Kilowatt Hours, British thermal units, or calories.

EPICENTER. The point on the earth's surface directly above the origin of an earthquake.

EQUILIBRIUM. Equilibrium exists in any system when the physical properties of elements within the system remain unchanged through time (steadystate).

EXTRUSIVE. Igneous rock that has been ejected onto the surface of the earth.

$\underline{F}$

FAHRENHEIT. A thermometric scale in which the melting point of ice is 32 degrees above zero and the boiling point of water is 212 degrees above zero $\left({ }^{0} \mathrm{~F}=9 / 5{ }^{\circ} \mathrm{C}+32\right)$.

FAULT. A fracture or fracture zone in the earth's crust along which there has been displacement of the sides relative to one another parallel to the fracture.

FISSURE. An extensive crack, break, or fracture in rock. A mere joint or crack persisting only for a few inches or even a few feet is not usually termed a fissure by geologists or miners, although in a strict physical sense, it is.

FLASHED STEAM. Steam produced by the boiling of superheated water upon release of confining pressure. 
FOLD. A curve or bend of a planar structure such as rock strata or bedding planes.

FOSSIL FUEL. A deposit of organic material containing stored solar energy that can be used as fuel. The most important are coal, natural gas and petroleum.

FRACTURE POROSITY. Porosity resulting from the presence of openings produced by the breaking or shattering of an otherwise less pervious rock.

FREE ENERGY. That portion of the energy of a system that is the maximum available for doing work.

FUMAROLE. A hole, vent, or geyser which emits steam or gaseous vapor; found usually in volcanic areas.

$\underline{\mathbf{G}}$

GEOCHEMISTRY. Chemistry of the earth; applied geochemistry uses chemical analyses to find economic resources, including minerals and geothermal fluids.

GEOLOGIC MAP. A map showing surface distribution of rock varieties, age relationships, and structural features.

GEOLOGY. A study of the planet earth; its composition, structure, processes, and history.

GEOPHYSICS. Physics of the earth; applied geophysics uses various methods of measuring physical characteristics of the earth's crust to locate economic resources.

GEOTHERMAL. Of or relating to the earth's natural heat.

GEOTHERMAL ENERGY. The internal energy of the earth, available to man as heated rocks or water.

GEOTHERMAL GRADIENT. The rate of increase of temperature in the earth with depth. The gradient near the surface of the earth varies from place to place, depending on the heat flow in the region and on the thermal conductivity of the rock. Approximate average geothermal gradient in the earth's crust is about $25^{\circ} \mathrm{C} / \mathrm{km}$.

GEOTHERMOMETER. A geochemical method which uses ground water chemistry to estimate the temperature of a geothermal reservoir.

GEYSER. A spring that throws forth intermittent jets of heated water or steam. The heated water results from the contact of ground water with hot rock.

GRABEN. An elongate, relatively depressed crustal unit or block that is bounded by faults on its long sides. It is a structural form that may or may not have topographic expression. 
GRAVITY SURVEY. Measurements of the gravitational field at a series of different locations over an area of interest. Interpretation of data may lead to the location of faults, folds and intrusive bodies.

$\underline{H}$

HEAT EXCHANGER. A device for transferring heat from one fluid to another. The fluids are usually (but not necessarify) separated by conducting walls.

HEAT FLOW. Dissipation of heat coming from within the earth by conduction (i.e., heat flow from a magma into its surroundings or heat generated radiation from the breakdown of radioactive elements) measured at the earth's surface; the average is about $1.5 \times 10^{6} \mathrm{cal} / \mathrm{cm}^{2} / \mathrm{s}$.

HEAT FLOW UNIT. One heat flow unit is equal to $1 \times 10^{6} \mathrm{cal} / \mathrm{cm}^{2} / \mathrm{s}$. or ca $41.85 \mathrm{milliwatts} / \mathrm{m}^{2} / \mathrm{s}$.

HEAT PUMP. A device which, by the consumption of work or heat, effects the transport of heat between a lower temperature and a higher temperature. In conventional usage, the term is usually limited to a device whose useful output is heat.

HIGH-TEMPERATURE RESERVOIRS. Reservoirs with base temperatures greater than $150^{\circ} \mathrm{C}$.

HORST. 1: A mass of rock that is 1imited by faults and which was uplifted but may or may not have topographic expression. 2: A block of the earth's crust separated by faults from adjacent relatively depressed blocks.

HOT WATER SYSTEM. A system that is dominated by a circulating liquid that transfers most of the heat and largely controls subsurface pressures, and is often characterized by hot springs that discharge at the surface.

HYBRID. An energy source used in conjunction with another energy source. Example: Geothermal used with wood waste or coal to produce electricity.

HYDROLOGY. The science that deals with the properties, distribution, and circulation of continental water on the surface, in the soil and underlying rocks, and in the atmosphere.

HYDROSTATIC LEVEL. The level at which water rises in a well due to the water pressure in the aquifer.

HYDROTHERMAL. An adjective applied to heated or hot aqueous-rich solutions, to the processes in which they are involved, and to the rocks, ore deposits, and alteration products produced by them. Hydrothermal solutions are of diverse sources, including magmatic, meteoric, and connate waters.

HYDROTHERMAL ALTERATION. The phase changes resulting from the interaction of hydrothermal fluids with pre-existing solid phases. Included are the chemical and mineralogical changes in rocks and soils brought about by the addition or removal of materials through the medium of hydrothermal fluids. 
IGNEOUS ROCK. Rock formed from a melt or magma by cooling and solidification. If the solidification occurred at depth, the rock is called "plutonic," if formed from magma erupted onto the surface, called "volcanic."

INTERMEDIATE TEMPERATURE RESERVOIR. A reservoir in which the fluid temperature is between $90^{\circ} \mathrm{C}$ and $150^{\circ} \mathrm{C}$.

INTRUSIVE. Having been forced while in a fluid state into or between other rocks, but solidifying before reaching the surface. Said of plutonic igneous rocks and contrasted with extrusive.

ISOTOPE. A subspecies of an element having a slightly different molecular weight due to differences in the number of neutrons in the molecular structure.

$\underline{J}$

JUVENILE WATER. Water that is drived from the interior of the earth and has not previously existed as atmospheric or surface water.

$\underline{K}$

KNOWN GEOTHERMAL RESOURCE AREA (KGRA). An area which the Mineral Land Classification Committee of the United States Geological Survey has designated as potentially valuable for production of geothermal energy; KGRAs are essentially confined to publ ic domain lands (under BLM administration), and their establishment is based on both scientific and competitive-interest criteria.

KILOWATT-HOUR ( $k$ whr). The energy represented by one kilowatt of power consumed for a period of one hour; equals $3,415 \mathrm{Btu}$ and/or $8.6 \times 10^{5}$ calories; in the U.S., the installed generating capacity supplies approximately $1 \mathrm{kwhr}$ of energy per person per hour.

$\underline{L}$

LIFE CYCLE COSTS. A summation of the acquisition, operation, maintenance, and disposal costs of an item from the date of purchase to the date of disposal.

LOW-TEMPERATURE RESERVOIR. Geothermal reservoirs with base temperatures less than $90^{\circ} \mathrm{C}$.

M

MAGMATIC WATER. Water that exists in or is derived from molten igneous rock or magma.

MEGAWATT. One thousand kilowatts. $M W_{\mathrm{e}}=$ electrical capacity in megawatts. $M W_{t}=$ thermal power in megawatts. 
METEORIC WATER. Rain water entering soil or rock and percolating downward.

METES \& BOUNDS. The boundaries or limits of a tract of land in which the bearing and length of boundary lines may be described by reference to local natural or artificial monuments such as a stream, ditch or road.

MICROEARTHQUAKE. A small earthquake, with Richter magnitude less than 3 , and which is normally not felt.

MUD VOLCANO. A cone-shaped mound with a maximum height of 250 feet built around a spring by mud brought to the surface by slowly escaping natural gas.

$\underline{N}$

Na-K-Ca GEOTHERMOMETER. A method of calculating the temperature of a geothermal reservoir from the relative concentrations of $\mathrm{Na}$ (sodium), $\mathrm{K}$ (potassium), and $\mathrm{Ca}$ (calcium) present in a geothermal fluid sample; it is based upon empirical data on the equilibrium solubilities of those ions as a function of temperature.

$\underline{P}$

PASSIVE SEISMIC METHOD. An exploration technique relying on naturally occurring seismic waves (e.g. from earthquakes).

PAYBACK. A method of determining the period of time required to recover the capital invested in a project.

PERMAFROST. Permanently frozen subsoil.

PERMEABILITY. The permeability of a rock is its capacity for transmitting a fluid. Degree of permeability depends upon the size and shape of the pores, the size and shape of their interconnections, and the extent of the latter. It is measured by the rate at which a fluid of standard viscosity can move a given distance through a given interval of time. The unit of permeability is the darcy.

PLATE TECTONICS. A study of the movement of the plates that make up the earth's crust. The boundaries of the continuously moving plates can be seen as ocean trenches, volcanic mountain chains such as the Alleutian Islands and Cascade Mountains, mid ocean ridges, and transform faults such as the San Andreas Fault.

POROSITY. The ratio of the aggregate volume of pore spaces in a rock or soil to its total volume; usually stated as a percent.

POWER. Rate at which work is done. Watts $(W), B t u / h r, c a l / s e c$.

PPB. Parts per billion, by weight.

PPM. Parts per million, by weight. 
PRESENT VALUE-PRESENT WORTH. The value at present (time zero) of a projected series of costs or revenues discounted at some interest rate (cost of capital or required return on investment) from the time they. occur to time zero.

$\underline{Q}$

QUAD. Equal to $10^{15} \mathrm{Btu}$.

$\underline{\mathrm{R}}$

RECONNAISSANCE. The initial investigation of a large area in order to locate prospects or targets.

REINJECTION. The injection of produced geothermal fluids back into the reservoir from which they came through disposal wells.

RESERVOIR. A natural underground container of liquids, such as oil, water, or gases. In general, such reservoirs were formed by local deformation of strata, changes of porosity, faulting, or intrusions.

RESISTIVITY. Electrical resistance per unit length in any material; this varies widely with rock type, porosity, temperature and salinity; usually expressed in OHM-meters.

RESISTIVITY METHOD. Observation of electric potential and current distribution at the earth's surface intended to detect subsurface variations in resistivity that may be related to geology, ground water temperature and quality, or parosity.

\section{$\underline{S}$}

SALINE. A term used to designate waters containing high concentrations of dissolved salts, such as sea water.

SALINITY. A measure of the total dissolved salts per volume of water; for comparision, sea water has a salinity of ca $35,000 \mathrm{ppm}$.

SATURATED VAPOR. A vapor that is in equilibrium with its liquid at a given temperature and pressure.

SCALING. Precipitation and deposition of dissolved solids in pipes or other containers (of geothermal or other fluids).

SEISMIC. Pertaining to an earthquake or earth vibration, including those that are artifically induced.

SINTER. A chemical sedimentary rock that forms by precipitation from hot or cold mineral waters of springs, lakes, or streams. 
SILICA GEOTHERMOMETER. A method of calculating the temperature of a geothermal reservoir from the concentration of $\mathrm{SiO}_{2}$ in a geothermal fluid sample; it is based upon empirical data on the equilibrium solubilities of quartz, chalcedony, and other silicate species as a function of temperature.

SODA SPRING. An alkali spring whose waters contain a high content of dissolved sodium salts, chiefly sodium carbonate.

SOLUBILITY. The equilibrium concentration of a salt in a solution which is dependent upon pressure and temperature.

SPACE HEATING. The process of supplying the required heat for the physical comfort of human beings in houses, offices, or enclosed industrial plants. The heat required for a typical domestic dwelling on an average winter day in the U.S. is about 27,000 BTU/hr. or $7.8 \mathrm{kw}$.

SPECIFIC HEAT. The quantity of heat necessary to raise the temperature of 1 gram of a given substance $1^{\circ} \mathrm{C}$.

STEAM. 1: The water is converted to steam when heated to the boiling point. 2: The pure gaseous phase of $\mathrm{H}_{2} \mathrm{O}$.

STRATUM. 1: A section of a formation that consists of approximately the same kind of rock material throughout. 2: A single sedimentary bed or layer, regardless of thickness.

SUBSIDENCE. 1: A sinking of a large part of the earth's crust. 2: Movement in which there is no free side and surface material is displaced vertically downward with little or no horizontal component.

SUPERHEATED. 1: A process of adding more heat than is necessary to complete a given phase change. 2: In magmas, the accumulation of more heat than is necessary to cause essentially complete melting, in such cases the increase in temperature of the liquid above the liquidus temperature for any major mineral components is called the superheat.

SUPERSATURATED. A solution that contains more of the solute than is normally present when equilibrium is established between the saturated solution and undissolved solute.

I

TECTONIC. Refers to those processes by which rocks of the crust and upper mantle are deformed (faulted, fractured, folded).

TECTONIC MAP. A map which shows major structural features produced by uplift, downwarp, or faulting, together with the major lineations within such features.

TEMPERATURE-GRADIENT SURVEY. The study of precisely measured temperatures at successive depths in a drill hole in order to determine the rate of temperature increase with depth. 
THERMAL GRADIENT. Pertains to the rate of increase or decrease in temperature with distance in a specified direction.

THERMAL SPRING. A spring displaying waters significantly higher than mean annual temperature for that area.

THERMO SYPHONING. The natural convective movement of hot water in heat exchangers.

TILTMETER. 1: A device for observing surface disturbances on a bowl of mercury, employed in an attempt to predict earthquakes. 2: An instrument used to measure displacement of the ground surface from the horizontal.

TON OF REFRIGERATION. The heat of fusion of one ton (more precisely 200.91 lbs.) of water. One ton of refrigeration $=288.000 \mathrm{Btu}=3.035 \mathrm{x}$ $10^{8} \mathrm{~J}$.

TRAVERTINE. Calcium carbonate $\left(\mathrm{CaCO}_{3}\right)$ of light color deposited from solution in ground and surface waters. Extremely porous or cellular varieties are known as calcareous tufa, calcareous sinter, or spring deposit. Travertine forms the stalactites and stalagmites of limestone caves and the filling of some veins and hot spring conduits.

TUFA. A porous or cellular variety of travertine.

TUNDRA. The treeless plains of arctic regions and their associated unique ecosystems.

$\underline{v}$

VAPOR-DOMINATED. A geothermal system in which pressures are controlled by vapor rather than by liquid.

VOLCANISM. Natural processes resulting in the formation, movement, eruption, and crystallization of magmas, forming volcanoes and volcanic rocks.

$\underline{W}$

WARM SPRING. A thermal spring whose temperature is appreciably above the local mean atmospheric temperature, but below that of the human body. Cf: HOT SPRING.

WATER TABLE. That surface of a body of unconfined ground water at which the pressure is equal to that of the atmosphere.

WATT. Unit of electric energy equal to $3.4 \mathrm{Btu} / \mathrm{hour}$.

WORK. The product of the force acting upon a body and the distance through which it moves. Work = force $x$ distance. The result is kinetic or potential energy. 


\section{APPENDIX 1}

\section{BIBLIOGAPHY OF GEOTHERMAL RESOURCE INFORMATION}

FOR

THE STATE OF WASHINGTON

by

Michael A. Korosec

April 1980

OPEN-FILE REPORT $80-4$

Prepared under Department of Energy Contract Number DE-AC07-79ET27014 (Geothermal Assessment of Washington State) 


\section{BIBLIOGRAPHY}

Armstrong, J. E.; Crandel1, D. R.; Easterbrook, D. J.; Noble, J. B., 1965, Late Pleistocene stratigraphy and chronology in southwestern Washington: Geological Society of America Bulletin, v. 76, no. 3, p. 321-330.

Banks, N. G.; Bennett, C. A.; Schmidt, J. M., 1978, Maps of photo lineaments and geomorphic features in the Spirit Lake quadrangle, Washington: U.S. Geological Survey Open-File Report 78-505, 2 sheets.

Blackwe11, D. D., 1969, Heat-flow determinations in the northwestern United States: Journal of Geophysical Research, v. 74, no. 4, p. 992-1007.

Blackwel1, D. D., 1974, Terrestrial heat-flow and its implications on the location of geothermal reservoirs in Washington. In Energy resources of Washington, Washington Division of Geology and Earth Resources Information Circular 50, p. 21-33.

Bloomquist, R. G., 1979, Geothermal energy in Washington - site data base and development status: Oregon Institute of Technology Geo-Heat Utilization Center, U.S. Department of Energy, DE-AC03-79SF1049, 192 p.

Bockheim, J. G.; Ballard, T. M., 1975, Hydrothermal soils of the crater of Mount Baker, Washington: Soll Sclence Society of America Proceedings, v. 39, no. 5. p. $997-10001$

Bonini, W. E., 1965, Gravity surveys in the northwestern United States: American Geophysical Union Transactions, v. 46, no. 3, p. 563-569. 
Bonini, W. E.; Hughes, W. D.; Danes, Z. F., 1974, Complete Bouguer gravity anomaly map of Washington: Washington Division of Geology and Earth Resources Geologic Map GM-11, scale 1:500,000.

Braile, L. W., 1970, The isostatic conditions and crustal structure of Mount St. Helens as determined from gravity data: University of Washington M.S. thesis, $37 \mathrm{p}$.

Campbell, K. V.; Miers, J. H.; Nichols, B. M•; Oliphant, J.; Pytlak, S.; Race, R. W.; Shaw, G. H.; Gresens, n. L., 1970, A survey of thermal springs in Washington State: Northwest Science, v. 44, p. 1-11.

Cantwell, T.; Nelson, P•; Webb, J.; Orange, A•, 1965, Deep resistivity measurements in the Pacific Northwest: Journal of Geophysical Research, v. 70, no. 8, p. $1931-1937$.

Cantwe11, T.; Orange, A., 1965, Further deep resistivity measurements in the Pacific Northwest: Journal of Geophysical Research, V. 70, no. 16, p. 4068-4072.

Condie, K. C.; Swenson, D. H., 1973, Compositional variations in three Cascade strata volcanoes - Jefferson, Rainier, and Shasta: Bulletin Volcanologique, v. 37, no. 2, p. 205-230.

Coombs, H. A., 1936, The geology of Mount Rainier National Park: University of Washington Publications in Geology, v. 3, no. 2, p. 131-212. 
Coombs, H. A., 1939, Mount Baker, a Cascade volcano: Geological Society of America Bulletin v. 50, no. 10, p. 1493-1509.

Crandell, D. R., 1969, Surficial geology of Mount Rainier National Park, Washington: U.S. Geological Survey Bulletin 1288, 41 p.

Crande11, D. R., 1969, The geologic story of Mount Rainier: U.S. Geological Survey Bulletin 1292, 43 p.

Crande11, D. R., 1971, Post-glacial lahars from Mount Ra1nier volcano, Washington: U.S. Geological Survey Professional Paper 677, 75 p.

Crandel1, D. R., 1973, Map showing potential hazards from future eruptions of Mount Rainfer, Washington: U.S. Geological Survey Map I-836, scale $1: 250,000$

Crande11, D. R., 1976, Preliminary assessment of potential hazards from future volcanic eruptions in Washington: U.S. Geological Survey Map MF-774, scale $1: 1,000$

Crandel1, D. R.; Mulilneaux, D. R., 1973, Pine Creek volcanic assemblage at Mount St. Helens, Washington: U.S. Geological Survey Bulletin 1383-A, 23 p.

Crande11, D. R.; Mullineaux, D. R., 1978, Potential hazards from future eruptions : of Mount St. Helens volcano, Washington: U.S. Geological Survey Bulletin 1383-C. 
Crande11, D. R.; Mullineaux, D.R॰; Miller, R. D.; Rubin, M., 1962, Pyroclastic deposits of Recent age at Mount Rainier, Washington. In Short Papers in the Geologic and Hydrologic Sciences, U.S. Geological Survey Professional Paper 450-D, p. D64-D68.

Crandell, D. R.; Mullineaux, D. R.; Rubin, M., 1975, Mount St. Helens volcano: recent and future behavior: Science, v. 187, p. 438.

Crande11, D. R.; Waldron, H. H., 1956, A Recent volcanic mudflow of exceptional dimensions from Mount Rainier, Washington: American Journal of Science, v. 254 , p. $349-362$.

Crosby, J. W., III, 1971, New developments in geothermal exploration. In Cole, B. L., Papers presented at First Northwest Conference on Geothermal Power: Washington State Department of Natural Resources.

Crosson, R. S.; Mayers, I. R., 1972, Report on geothermal ground noise measurements in Washington State: Washington Division of Mines and Geology OpenFile Report, $16 \mathrm{p}$.

Crowder, D. F.; Tabor, R. W.; Ford, A. B., 1966, Geologic map of the Glacier Peak quadrangle, Snohomish and Chelan Counties, Washington: U.S. Geological Survey Geologic Quadrangle Map. GQ-473, scale 1:62,500.

Cullen, J. M•, 1978, Impact of a major eruption of Mount Rainier on public service delivery systems in the Puyallup Valley, Washington: University of Washington M.S. thesis, $195 \mathrm{p}$. 
Danes, Z. F., 1964, Gravity survey of Mount Rainier, Washington [abstract]: American Geophysical Unions Transactions, v. 45, p. 640.

Danes, 2. F., 1969, Gravity results in western Washington: American Geophysical Union Transactions, v. 50, p. 548-550.

Dehlinger, P.; Chiburis, E. F.; Collver, M. M., 1965, Local travel time curves and their geologic implication for the Pacific Northwest states: Bulletin of the Seismological Society of America, v. 55, no. 3, p. 587-607.

Easterbrook, D. J., 1975, Mount Baker eruptions: Geology, v. 3, no. 12, p. $679-682$.

Easterbrook, D. J., 1976, Pleistocene and Recent volcanic activity of Mount Baker, Washington: Geological Society of America, Abstracts with Programs, v. 8 , no. 6, p. 849 .

Ellingson, J. A., 1968, Late Cenozoic volcanic geology of the White Pass, Goat Rocks area, Cascade Mountains, Washington: Washington State University Ph. D. thes1s, $112 \mathrm{p}$.

Ellingson, J. A., 1969, Geology of the Goat Rocks volcano, southern Cascade Mountains, Washington: Goological Society of America Abstracts with Programs, Part 3, Cordilleran Section, p. 15.

Ellingson, J. A., 1972, The rocks and structure of the White Pass area, Washington: Northwest Science, v. 46, p. 9-24. 
Fiske, R. S., 1960, Stratigraphy and structure of lower and middle Tertiary rocks, Mount Rainier National Park, Washington: John Hopkins University, Ph. D. thesis, $163 \mathrm{p}$.

Fiske, R. S.; Hopson, C. A.; Waters, A. C., 1963, Geology of Mount Rainier National Park, Washington: U.S. Geological Survey Professional Paper $444,93 \mathrm{p}$

Ford, A. B., 1957, Petrology of the Sulphur Mountain area, Glacier Peak quadrangle, Washington: University of Washington M.S. thesis, 103 p.

Ford, A. B., 1959, Geology and petrology of the Glacier Peak quadrangle, northern Cascades, Washington: University of Washington Ph. D. thesis, $374 \mathrm{p} \cdot$

Fowler, C. S., 1935, The origin of the sulfur deposits of Mount Adams: M.S. State College of Washington, M. S. thesis, 23 p.

Frank, D.; Meir, M. F.; Swanson, D. A., 1977, Assessment of increased thermal activity at Mount Baker, Washington: U.S. Geological Survey Professional Paper 1022-A, 49 p.

Frank, D.; Post, A.; Friedman, J. D., 1975, Recurrent geothermally induced debris avalanches on Boulder Glacier, Mount Baker, Washington: Journal of Geophysical Research, v. 3, no. 1, p. 77-87.

Friedman, J. D., 1972, Aerial thermal surveillance of volcanoes of the Cascade Range, Washington, Oregon, and northern California: E.0.S., v. 53, no. 9, p. 533. 
Friedman, J. D., Frank, D., 1980, Thermal surveillance of active volcanoes using the Landstat-1 DCS: Part 2, IR Surveys, radiant flux, and total heat discharge from Mount Baker volcano, Washington, between 1970 and 1975, Final Report: U.S. Geological Survey for Goddard Space Flight Center [in press].

Friedman, J. D., Frank, D., 1977, Thermal survelllance of active volcanoes using the Landstat I data collection system: Part 3, Heat discharges from Mount St. Helens, Washington: U.S. Geological Survey Open-File Report 77-541, $30 \mathrm{p}$.

Gizienski, S. F.; McEuen, R. B.; Birkhahn, P. C., 1975, Regional evaluation of the geothermal resources potential in central Washington state: Washington Public Power Supply System, 113 p.

Hammond, P. E., 1973, Preliminary geologic maps of the southern Cascade range, Washington: Washington Division Mines and Geology Open-File Report 73-3, 5 sheets.

Hammond, P. E., 1974, Brief outline to volcanic stratigraphy and guide to geology of southern Cascade Range, Washington, and northern Cascade Range, Oregon: Geothermal Field Trip, Oregon Department of Geology, June $24-29,1974$.

Hammond, P. E., 197.5, Preliminary geologic map and cross sections with emphasis on Quaternary volcanic rocks, southern Cascade Mountains, Washington Division Geology and Earth Resources Open-File Report 75-13, scale $1: 24,000$ 
Hammond, P. E., Bentley, R. D.; Brown, J. C; Ellingson, J. A.; Swanson, D. A., 1977, Volcanic stratigraphy and structure of the southern Cascade Range, Washington: Field Trip No. 4, Geological Society of America, 90 th Annual meeting, Seattle, Washington.

Hammond, P. E.; Pedersen, S. A.; Hopkins, K. D.; Aiken, D.; Harle, D. S.; Danes, Z. F.; Kohicek, D. L.; Stricklin, C. R., 1976, Geology and gravimetry of the Quaternary basaltic volcanic field, southern Cascade Range, Washington. In Pezzotti, C. (editor), Proceedings, Second U.N. Symposium on development and use of geothermal resources, San Francisco, 1975, p. 397-405.

Harris, S. L., 1976, Fire and ice: the Cascade volcanoes: Pacific Search Press, Seattle, Washington, 320 p.

Harle, D. S., 1974, Geology of the Baby Shoe Ridge area, southern Cascades, Washington: Oregon State University M.S. thesis, $71 \mathrm{p}$.

Hopkins, K. D., 1976, Geology of the south and east slope; of Mount Adams volcano, Washington: University of Washington $\mathrm{Ph}$. D. thesis, Seattle, $143 \mathrm{p}$.

Hopson, C. A.; Waters, A. C.; Bender, V. R.; Rubin, M., 1962, The latest eruption from Mount Rainier volcano: Journal of Geology, v. 70. p. $635-646$.

Hopson, C. A., 1971, Eruptive sequence at Mount St. Helens, Washington: Geological Society of America Abstract with Programs, vol. 3, no. 2, p. 138. 
Hyde, J. H., 1970, Geologic setting of Merrill Lake and evaluation of volcanic hazards in the Kalama River valley near Mount St. Helens, Washington: U.S. Geological Survey Open-File Report, $15 \mathrm{p}$.

Hyde, J. H., 1973, Late Quaternary volcanic stratigraphy of the south flank of Mount St. Helens, Washington- "niversity of Washington Ph. D. thesis, Seattle, $114 \mathrm{p}$.

Hyde, J. H., 1975, Upper Pleistocene pyroclastic-flow deposits and lahars south of Mount St. Helens volcano, Washington: U.S. Geological Survey Bulletin $1383-\mathrm{B}, 20 \mathrm{p}$

Hyde, J. H.; Crande11, D. R., 1975, Origin and age of post-glacial deposits and assessment of potential hazards from future eruptions of Mount Baker, Washington: U.S. Geological Survey Open-File Report 75-286, 22 p.

Hyde, J. H.; Crandell, D. R., 1978, Post-glacial volcanic deposits at Mount Baker, Washington, and potential hazards from future eruptions: U.S. Geological Survey Professional Paper 1022-c, $17 \mathrm{p}$.

Johnson, S. H.; Couch, R. W., 1970, Crustal structure in the north Cascade Mountains of Washington and British Columbia from selsmic refraction measurements: Bulletin of the Selsmological Society of America, $v, 60, \quad$, no. 4, p. 1259-1269.

Kiver, E. P., 1975, Washington's geothermal ice caves: Pacific Search, vo 10, no. 3, p. 11 . 
Kiver, E. P., 1978, Geothermal ice caves and fumaroles, Mount Baker volcano: 1974-1977 [abstract]: Geological Society of America Abstracts with Programs, v. 10, no. 3, p. 112 .

Kiver, E. P., 1978, Mount Baker's changing fumaroles: The Ore Bin, v. 40, no. 8, p. 145 .

Kiver, E. P•; Snavely, J•; Snavely, D. F., 1977, Hydrogen sulfide fumes at the summit of Mount Rainier volcano, Washington: Northwest Science, v. 51, no. 1, p. 31-35.

Konicek, D. L., 1974, Geophysical survey in south-central Washington: University of Puget Sound M.S. thesis, 35 p.

Konice'- D. L., 1975, Geophysical survey in south-central Washington: Northwest Science, v. 49, no. 2, p. 106-117.

Lange, I. M.; Avent, J. C., 1975, Ground-based thermal infrared survey of Mount Rainier volcano, Washington: Geological Society of America Abstracts with Programs, v. 7, no. 5, p. 619.

Livingston, V. E., Jr., 1972, Geothermal energy in Washington. In Geothermal overviews of the western United States, First National Conference: Geothermal Resources Council, El Centro, California, February 16-18, 1972, Section L, 17 p. 
Malone, S. D., 1976, Deformation of Mount Baker volcano by hydrothermal heating: E.0.S. v. 57, no. 12, p. 1016 .

McEuen, R. B.; Birkhahn, P. C.; Pinçkney, C. J., 1976, Predictive regionalization of geothermal resource potential: In Pezzotti, C. (ed.), Proceedings, Second U.N. Symposium on development and use of geothermal resources, San Francisco, 1975, p. 1121.

McLane, J. E.; Finkelman, R. B.; Larson, R. R., 1976, Mineralogical examination of particulate matter from the fumaroles of. Sherman Crater, Mount Baker, Washington (abstract): E.0.S., v. 57, no. 2, p. 89.

Moxham, R. M., 1970, Thermal features of volcanoes in the Cascade Range as observed by aerial infrared surveys: Bulletin Volcanologique, v. 34 , no. 1 , p. 77-106.

Moxham, R. M.; Boynton, G. R.; Cote, C. E., 1973, Satellite telemetry of fumarole temperatures; Mount Rainier, Washington: Bulletin Volcanologique, v. 36 ; ho. $1, \mathrm{p}, 191-199$.

Moxham, R. M.; Crandel1, D. R.; Mariott, W. E., 1965, Thermal Features at "ount Rainier, Washington, as revealed by Infrared surveys: U.S. Geological Survey Professional Paper 525-D, p. 93-100.

Mull1neaux, D. R.; Crande11, D. R., 1962, Recent lahars from Mount St. Helens, Washington: Geological Soclety of America Bulletin v. 73, p. 855-970, 
Mullineaux, D. R.; Hyde, J. H.; Meyer, R., 1972, Preliminary assessment of upper Pleistocene and Holocene pumaceous tephra from Mount St. Helens volcano, southern Washington: Geological Society of America, Abstracts with Programs, v. 4, no. 3, p. 204-205.

Mullineaux, D. R.; Sigafoos, R. S.; Hendricks, E. L., 1969, A historic eruption of Mount Rainier, Washington: U.S. Geological Survey Professional Paper $650-B$, p. $315-318$.

Mundorff, M. J., 1964, Geology and ground water conditions of Clark County, Washington, with a description of a major alluvial aquifer along the Columbia River: U.S. Geological Survey Water Supply Paper 1600, 268 p.

Phillips, K. N., 1942, Fumaroles of Mount St. Helens and Mount Adams: Mazama, v. 23 , no. 12 , p. $37-42$.

Radke, L. F.; Hobbs, P. V.; Stith, J. L., 1976, Airborne measurements of gases and aerosols from volcanic vents on Mount Baker: Geophysical Research Letters v. 3, no. 2, p. 93-96.

Russe11, R. H., 1972, Geothermal energy potential of Washington State: Washington Department of Ecology, 23 p.

Russe11, R. H., 1973, Geothermal Energy; potential of Washington State: Geothermal Energy Magazine, v. 1, no. 4, p. 39-48.

Sato, M.; Malone, S. D.; Moxham, R. M., 1977, Monitoring of fumarolic gas at Sherman Crater, Mount Baker, Washington (abstract): E.0.S. v. 57, no. 2 , p. 88 . 
Schuster, J. E., 1973, The search for hot rocks - Geothermal exploration, Northwest: Washington Division of Geology and Earth Resources Reprint $11, \mathrm{p} .4$

Schuster, J. E., 1974, Geothermal energy potential of Washington: In Energy resources of Washington, Washington Division of Geology and Earth Resources Information Circular 50, p. 5.

Schuster, J. E.; Blackwe11, D. D.; Hammond, P. E.; Huntt1ng, M. T., 1978, Heat flow studies in the Steamboat Mountain-Lemel Rock area, Skamania County, Washington: Washington Division of Geology and Earth Resources Information Circular $62,56 \mathrm{p}$.

Sheppard, R. A., 1967, Petrology of a late Quaternary potassium-rich andesite from Mount Adams, Washington: U.S. Geological Survey Professional Paper $575-C_{\text {; }}$ P. 55-59.

Sheppard, R. A., 1967, Geology of the Simcoe Mountains volcanic area, Washington: Washingtón Division of Mines and Geology Geologic Map GM-3, scale $1: 250,000$

Stavert, L., 1971, A geochemical reconnaissance investigation of Mount Baker andesite: Western Washington State College M.S. thesis, 60 p.

Stricklin, C. R., 1975, Geophysical Survey of the Leme1 Rock - Steamboat Mountain area, Washington: University of Puget Sound M.S. thesis, $23 \mathrm{p}$. 
Swan, V. L., 1978, Mount Baker volcanics: (abstract) American Geophysical Unior meeting, Tacoma.

Swanson, D. A., 1964, The middle and late Cenoźoic volcanic rocks of the Tieton River area, south-central Washington: Johns Hopkins University Ph. D. thesis, 329 p.

Swanson, D. A., 1966, Tieton volcano, a Miocene eruptive center in the southern Cascade Mountains, Washington: Geological Society of America Bulletin, v. 77, p. $1293-1314$.

Swanson, D. A., 1978, Geologic map of the Tleton River area, Washington: U.S. Geological Survey Miscellaneous maps, MF-968, scale $1: 48,000$.

Swanson, D. A.; Wright, T. L.; Zietz, I., 1979, Aeromagnetic map and geologic interpretation of the west-central Columbia Plateau, Washington and adjacent Oregon: Geophysical Investigations, Map GP-917.

Swenson, D. H., 1973, Geochemistry of three Cascade volcanoes: New Mexico University of Mining and Technology M.S. thesis, 101 p. -

Tabor, R. W., Cady, W. M., 1978, The structure of the Olympic Mountains, Washington - Analysis of a subduction zone: U.S. Geological Survey Paper 1033, $38 \mathrm{p}$.

Tabor, R. W., Cady, W. M., 1978, Geologic map of the $01 y m p i c$ Peninsula, Washington: U.S. Geological Survey, 2 maps, scale $1: 125,000$. 
Tabor, R. W.; Crowder, D. F., 1969, On batholiths and volcanoes - Intrusion and eruption of late Cenozoic magmas in the Glacier Park area, north Cascades, Washington: U.S. Geological Survey Professional Paper 604, $50 \mathrm{p}$.

U.S. Geological Survey, 1977, Aeromagnetic maps of part of northern Washington: U.S. Geological Survey Open-File Report 77-254, 2 sheets, scale 1:62,500.

Unger, J. D.; Decker, R. W., 1970, The microearthquake activity of Mount Rainier, Washington: Seismological Society of America Bulletin, v. 60, p. 2023-2035.

Unger, J. D.; Mills, K. F., 1972, Microearthquakes at Mount Rainier - 1969: Selsmological Society of America Bulletin, v. 62, p. 1079-1081.

Unger, J. D.; Mills, K. F., 1973, Earthquakes near Mount St, Helens, Washington: - Geological Society of America Bulletin, v. 84, no. 3, p. 1065-1067.

Valentine, G. M., 1960, Inventory of Washington minerals - Part I, Nonmetallic minerals, revised by M. T. Hutting: Washington State Division of Mines and Geology Bulletin 37, 2 volumes, text and maps, 175 p. plus 83 p.

Verhoogan, J., 1937, Mount st. Helens - A recent Cascade volcano: California University Publications in Geological Science, v. 24, no. 9, p. 263-302.

Washington Division of Geology and Earth Resources, 1974, Energy resources of Washington: Information Circular 50, $158 \mathrm{p}$. 
Waters, A. C., 1973, The Columbia River Gorge Basalt Stratigraphy, ancient lava dams, and landslider dams. In Beaulieux, J. D., chairman, Geologic field trips in northern Oregon and southern Washington: Oregon Division of Geology and Mineral Industries; Bulletin 77, p. 133-162.

Weaver, C. S., 1976, Seismic events on Cascade volcanoes, Ph.D. dissertation, University of Washington, Ph. D. thesis, $158 \mathrm{p}$.

Weaver, C. S., 1976, Seismic events on Cascade volcanoes [abstract]: University of Washington $\mathrm{Ph}$. D. thesis, Seattle: In Dissertation Abstracts International, v. 37, no. 3, p. 1157-B.

Wise, W. S., 1961, The geology and minerology of the Wind River area, Washington, and the stability relations of celadonite: Johns Hopkins University, $\mathrm{Ph}$. D. thesis, p. 258 .

Wise, W., 1970, Cenozoic volcanism in the Cascade mountains of southern Washington: Washington Division of Mines and Geology Bulletin 60, 45 p. 